U.S. Department of the Interior

U.S. Geological Survey

\title{
Evaluation of Bridge-Scour Data at Selected Sites in Ohio
}

By K. Scott Jackson

Water-Resources Investigations Report 97-4182

Prepared in cooperation with the

OHIO DEPARTMENT OF TRANSPORTATION and the

U.S. DEPARTMENT OF TRANSPORTATION

FEDERAL HIGHWAY ADMINISTRATION

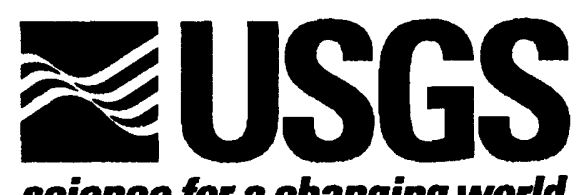




\section{U.S. DEPARTMENT OF THE INTERIOR BRUCE BABBITT, Secretary \\ U.S. GEOLOGICAL SURVEY \\ Mark Schaefer, Acting Director}

Any use of trade, product, or firm names is for descriptive purposes only and does not imply endorsement by the U.S. Government.

For additional information write to:

District Chief

U.S. Geological Survey

975 West Third Avenue

Columbus, Ohio 43212-3192
Copies of this report can be purchased from:

USGS Branch of Information Services

Box 25286

Denver, Colorado 80225 


\section{CONTENTS}

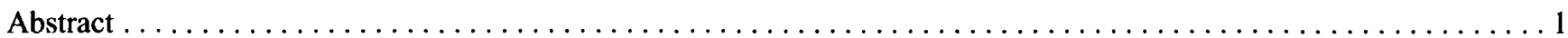

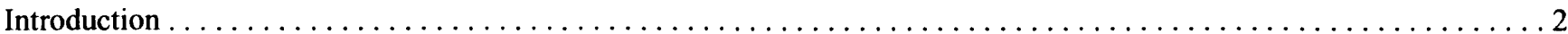

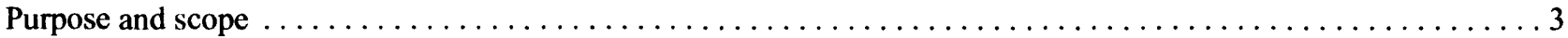

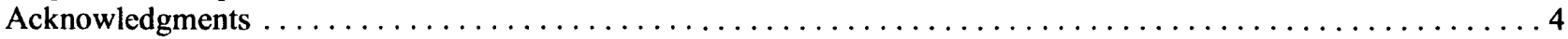

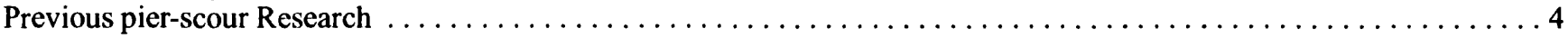

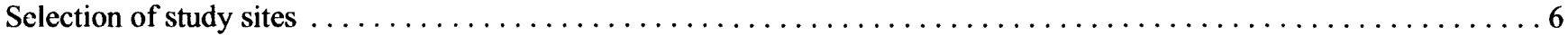

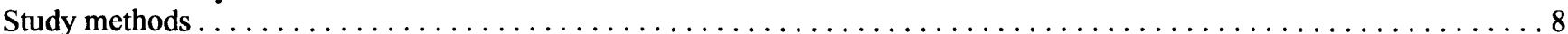

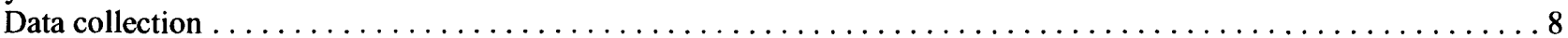

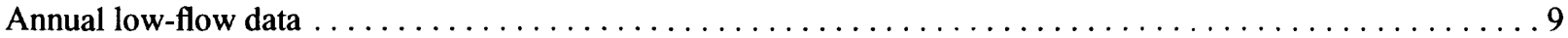

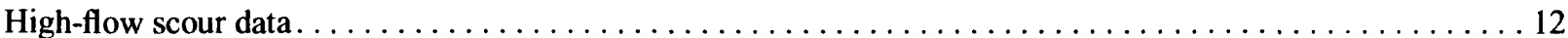

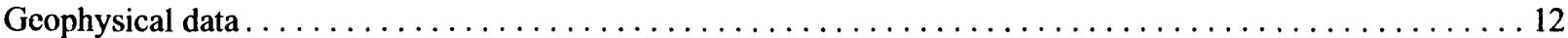

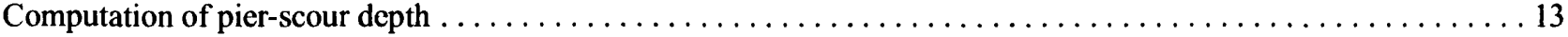

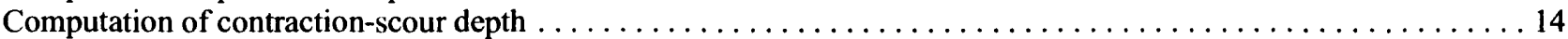

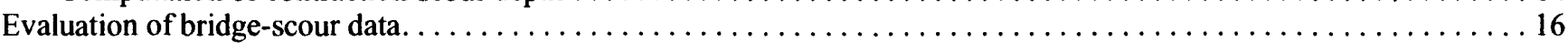

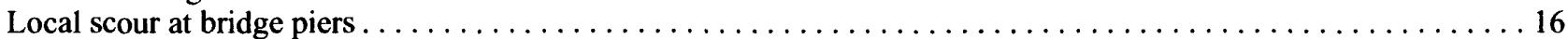

Analysis of all cases of observed pier-scour data $\ldots \ldots \ldots \ldots \ldots \ldots \ldots \ldots \ldots$

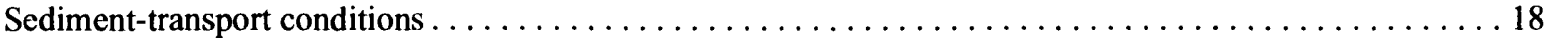

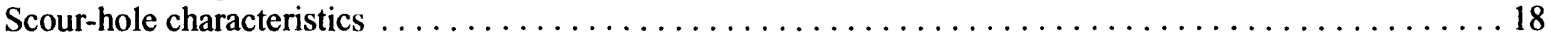

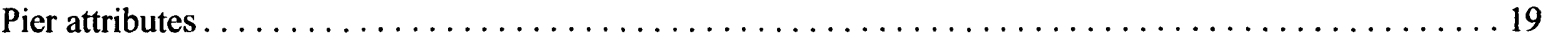

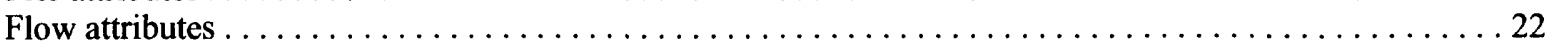

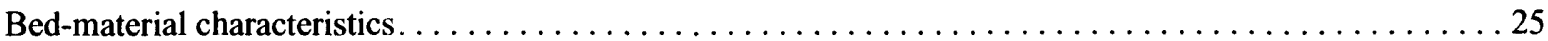

Analysis of cases of observed pier-scour data with approach-flow

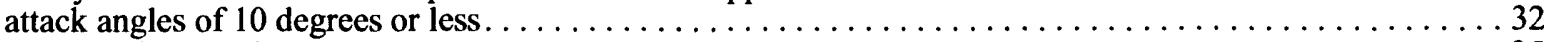

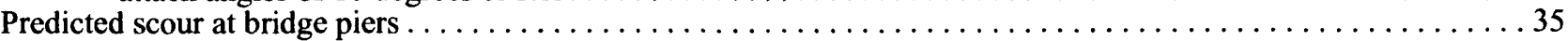

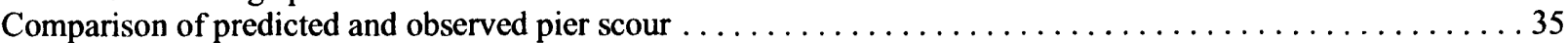

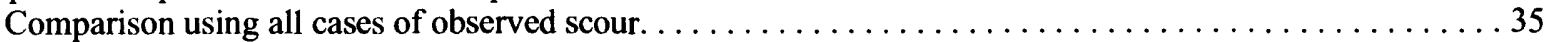

Comparison using cases of observed scour with approach-flow

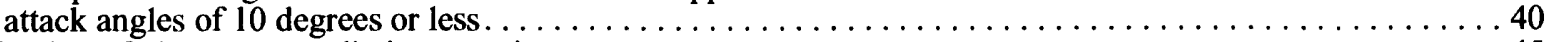

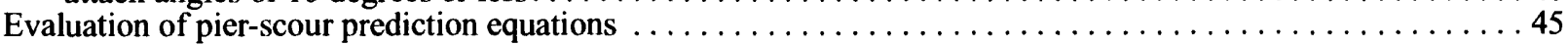

Evaluation using all cases of observed scour. $\ldots \ldots \ldots \ldots \ldots \ldots \ldots \ldots \ldots \ldots \ldots$

Evaluation using cases of observed scour with approach-flow

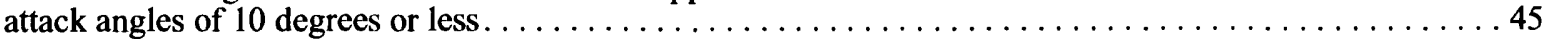

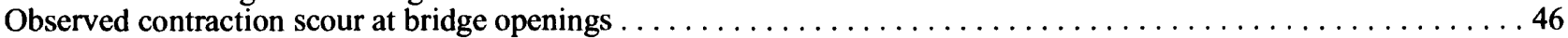

Analysis of approach-section channel stability $\ldots \ldots \ldots \ldots \ldots \ldots \ldots \ldots$

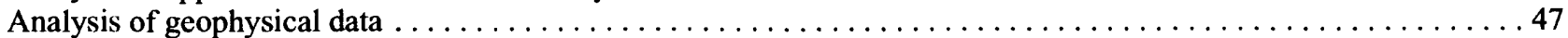

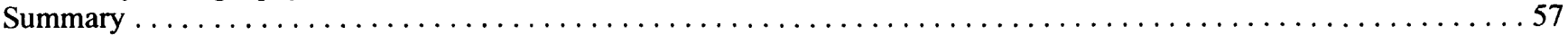

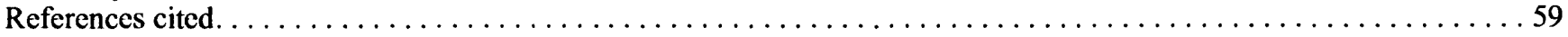

Appendix

Description of pier-scour equations, by David S. Mueller and K. Scott Jackson . . . . . . . . . . . . . 68

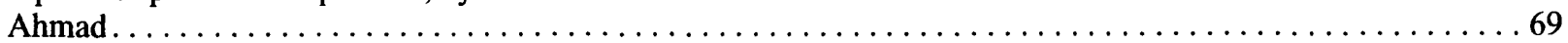

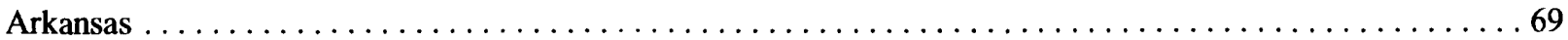

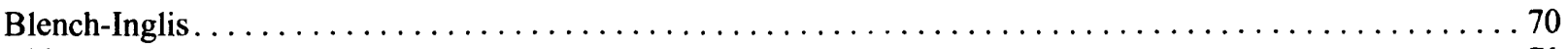

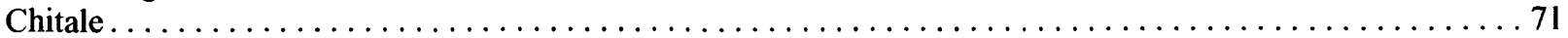

Federal Highway Administration Hydraulic Engineering Circular 18 (FHWA HEC 18) . . . . . . . . 72

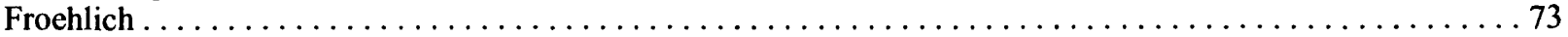

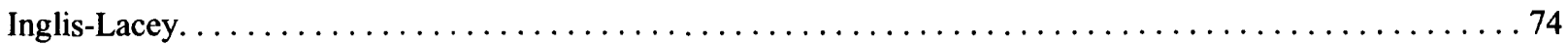

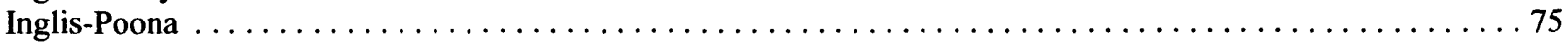

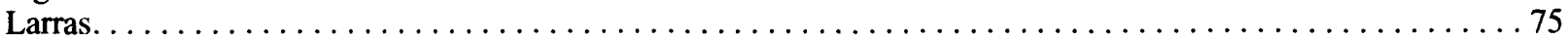

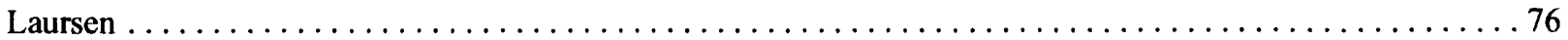

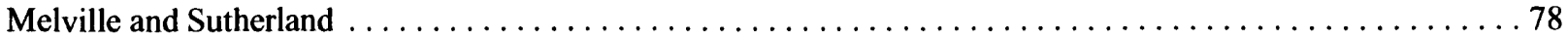

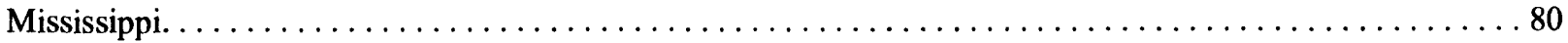

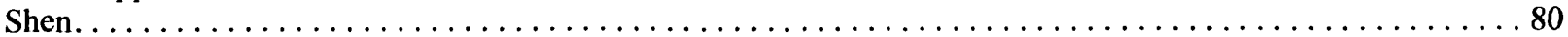




\section{FIGURES}

1. Graph showing relation of normalized scour depth to flow intensity at cylindrical piers in

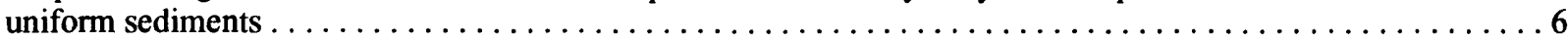

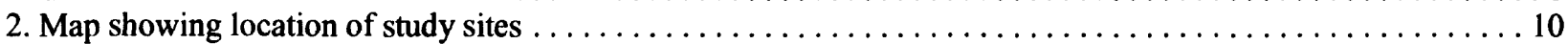

3. Sketch illustrating determination of the concurrent ambient bed level and the resulting

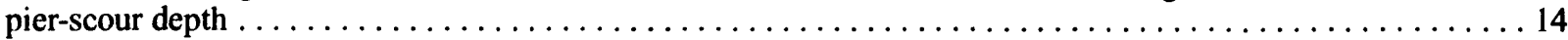

4-8. Graphs showing:

4. Summary of the scour measurement discharges ranked by recurrence-interval ranges for selected unregulated bridge-scour study sites in Ohio $\ldots \ldots \ldots \ldots \ldots \ldots \ldots \ldots \ldots \ldots \ldots \ldots$

5. Characteristics of measured pier-scour holes at bridge-scour study sites in Ohio:

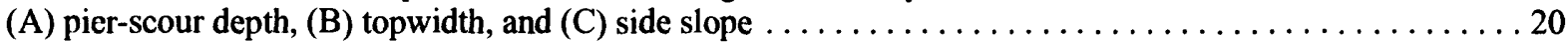

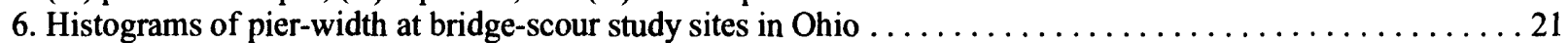

7. Relation of pier-scour depth to pier width at bridge-scour study sites in Ohio $\ldots \ldots \ldots \ldots \ldots \ldots \ldots \ldots 23$

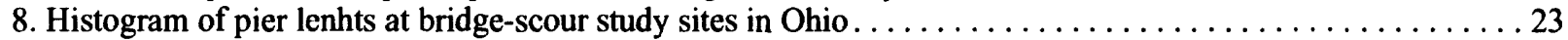

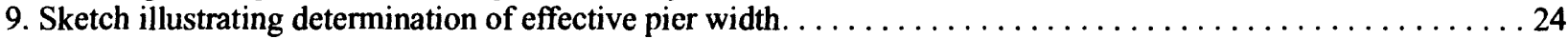

10-32. Graphs showing:

10. Characteristics of pier alignment at bridge-scour study sites in Ohio:

(A) effective pier width and (B) pier alignment to the approach flow. . . . . . . . . . . . . . . . 24

11. Relation of pier-scour depth to effective pier width at

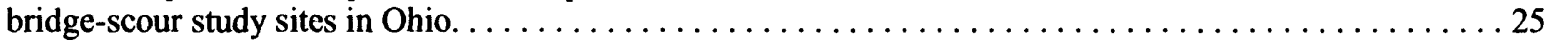

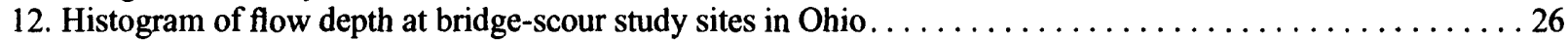

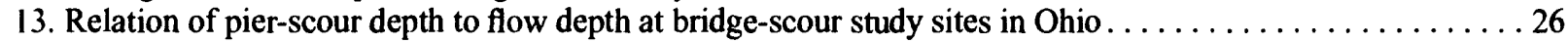

14. Relation of normalized pier-scour depth to normalized flow depth at

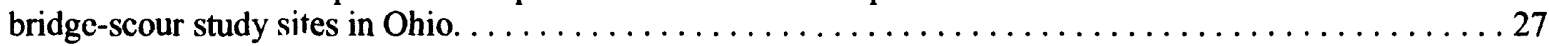

15. Characteristics of flow attributes at bridge-scour study sites in Ohio: (A) pier approach-flow velocity, (B) critical velocity, (C) flow intensity, the ratio of pier

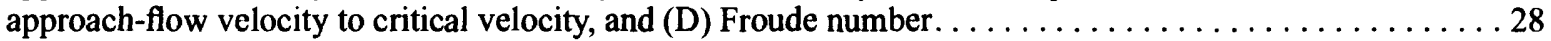

16. Relation of normalized scour depth to flow intensity at

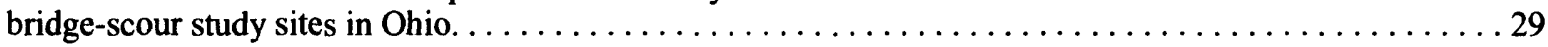

17. Relation of normalized scour depth to Froude number at

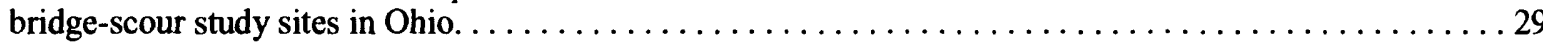

18. Histograms of selected bed-material samples from bridge-scour study sites in Ohio: (A) median grain size $\left(d_{50}\right)$ of pier-area samples, $(\mathrm{B}) d_{95}$ of pier-area samples,

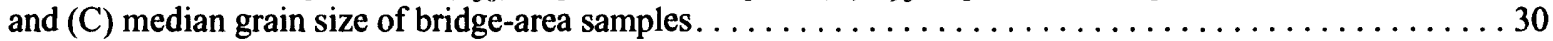

19. Boxplots of $d_{50}$ grain size for all bed-material samples collected at bridge-scour study sites in Ohio, identified by sampling-area location $\ldots \ldots \ldots \ldots \ldots \ldots \ldots \ldots \ldots \ldots$

20. Relation of normalized scour depth to median grain size of pier-area samples at

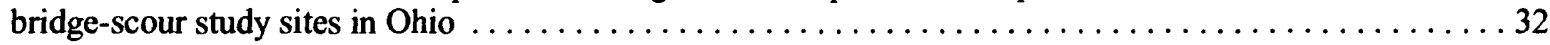

21. Relation of normalized scour depth to the ratio of pier width to median grain size of

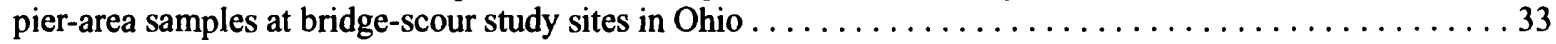

22. Relation of normalized scour depth to $d_{95}$ of pier-area samples from

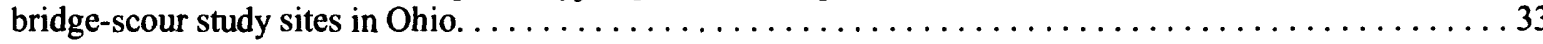

23. Relation of normalized scour depth to the geometric standard deviation of particle-size distribution for pier-area samples from bridge-scour

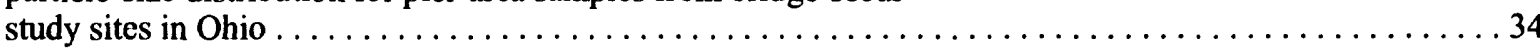

24. Relation of predicted pier-scour depths from the Ahmad, Arkansas, Blench-Inglis I, and Blench-Inglis II equations to scour depths observed at bridge-scour

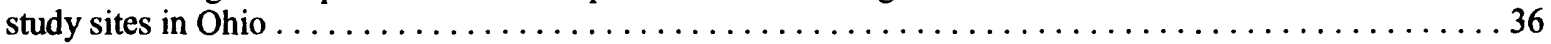

25. Relation of predicted pier-scour depths from the Chitale, FHWA HEC 18, Froehlich, andFroehlich Design equations to scour depths observed at bridge-scour study sites in Ohio.

26. Relation of predicted pier-scour depths from the Inglis-Lacey, Inglis-Poona I, Inglis-Poona II, and Larras equations to scour depths observed at bridge-scour study sites in Ohio. .

27. Relation of predicted pier-scour depths from the Laursen, Melville and Sutherland, and Mississippi equations to scour depths observed at bridge-scour study sites in Ohio

28. Relation of predicted pier-scour depths from the Shen and Shen-Maza equations toscour depths observed at bridge-scour study sites in Ohio. 
29. Distributions of predicted and observed pier-scour depths at bridge-scour study sites in Ohio.

30. Distributions of residuals between predicted and observed pier-scour depths at

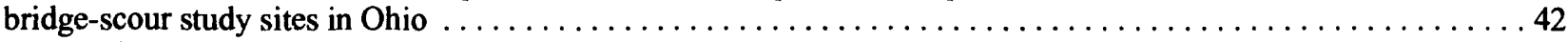

31. Distributions of predicted and observed pier-scour depths with approach-flow attack angles of 10 degrees or less at bridge-scour study sites in Ohio

32. Distributions of residuals between predicted and observed pier-scour depths with approach-flow attack angles of 10 degrees or less at bridge-scour study sites in Ohio.

33-37. Graphs showing annual mean streambed elevations and the mean of the annual mean streambed elcvations of the approach cross sections obtained during annual low-flow surveys:

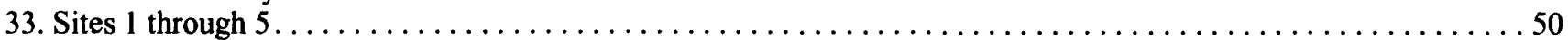

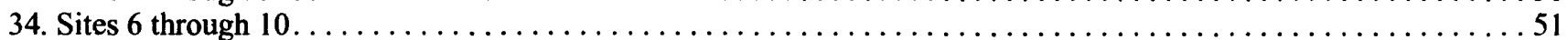

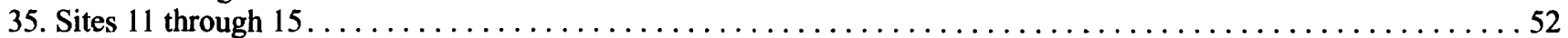

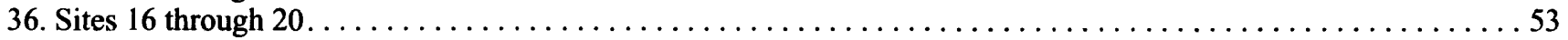

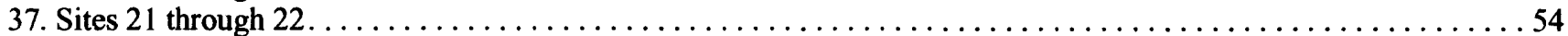

38. Ground-penetrating radar cross section measured at upstream side of bridge along U.S. Route 50 over Salt Creek at Londonderry, Ohio; left to right

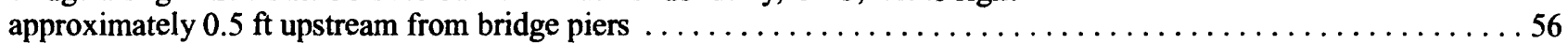

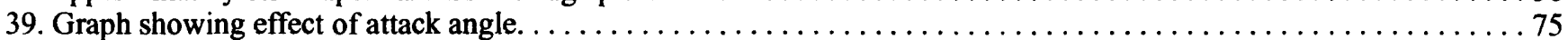

40. Graph showing shields chart for determination of the critical shear velocity of uniform

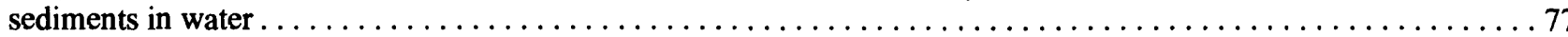

\section{TABLES}

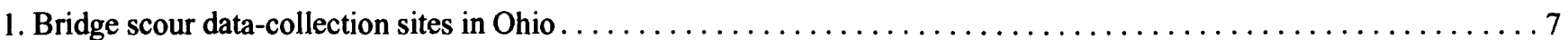

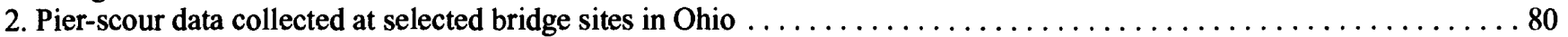

3. Correlation data for selected scour factors for 84 cases of observed pier scour in Ohio . . . . . . . . . . . . . . 19

4. Data for scour-measurement sites where contraction scour was observed $\ldots \ldots \ldots \ldots \ldots \ldots \ldots \ldots \ldots \ldots \ldots \ldots$

5. Summary of annual mean streambed elevation data for approach sections at

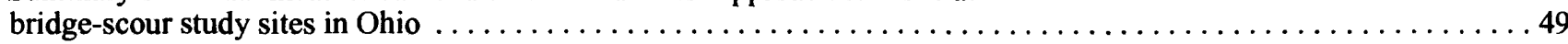

6. Summary of 1990 ground-penetrating-radar surveys at bridge-scour study sites in Ohio $\ldots \ldots \ldots \ldots \ldots \ldots \ldots \ldots 5$

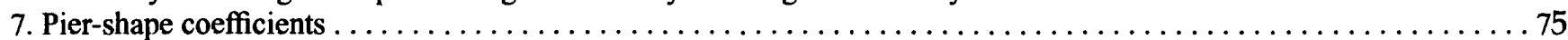

\section{CONVERSION FACTORS, ABBREVIATIONS, AND VERTICAL DATUM}

\begin{tabular}{rll}
\hline Multiply & By & To obtain \\
\hline inch (in.) & 25.4 & millimeter \\
foot $(\mathrm{ft})$ & 0.3048 & meter \\
foot per second $(\mathrm{ft} / \mathrm{s})$ & 0.3048 & meter per second \\
square $\mathrm{mile}\left(\mathrm{mi}^{2}\right)$ & 2.590 & square kilometer \\
cubic foot $\left(\mathrm{ft}^{3}\right)$ & 0.02832 & cubic meter \\
cubic foot per second $\left(\mathrm{ft}^{3} / \mathrm{s}\right)$ & 0.02832 & cubic meter per second \\
millimeter $(\mathrm{mm})$ & 0.032808 & foot
\end{tabular}

Sea level: In this report, "sea level" refers to the National Geodetic Vertical Datum of 1929 (NGVD of 1929)-- a geodetic datum derived from a general adjustment of the first-order level nets of both the United States and Canada, formerly called Sea Level Datum of 1929 


\section{SYMBOLS}

b Width of the bridge pier, feet.

$b_{e} \quad$ Width of the bridge pier projected normal to the approach flow (effective pier width), feet.

$$
b_{e}=b \cos (\alpha)+L \sin (\alpha)
$$

c Pier location code; 0 assigned for piers in the main channel, and 1 assigned for piers on the banks of the main channel or flood plain.

$d_{m} \quad$ Mean grain size of the bed material, millimeter.

$d_{95}$ Grain size of the bed material for which 95 percent are finer, millimeter.

$d_{84}$ Grain size of the bed material for which 84 percent are finer, millimeter.

$d_{50}$ Median grain size of the bed material, millimeter.

$d_{50 a}$ Median grain size of the armor layer, millimeter.

$d_{16}$ Grain size of the bed material for which 16 percent are finer, millimeter.

$F$ Froude number of the flow just upstream from the pier, defined as $\frac{\mathrm{V}_{\mathrm{o}}}{\sqrt{\mathrm{gy}_{\mathrm{o}}}}$.

$F_{\mathrm{p}} \quad$ Pier Froude number, defined as $\frac{\mathrm{V}_{\mathrm{o}}}{\sqrt{\mathrm{gb}}}$.

$f_{b} \quad$ Bed factor, defined as, $\frac{V^{2}}{y}$, feet per second squared.

g Acceleration of gravity, 32.2 feet per second squared.

$\mathrm{K}$ A coefficient that is a function of boundary geometry, abutment shape, width of the piers, shape of the piers, and angle of the approach flow. On the basis of numerous model studies, Ahmad (1962) suggested that, for calculation of scour at piers and abutments, the coefficient should be in the range of 1.7 to 2.0. For this investigation, it was assumed to be 1.8 .

$K_{d} \quad$ Coefficient based on sediment size.

$\mathrm{K}_{\mathrm{I}}$ Coefficient based on flow intensity.

$\mathrm{K}_{\mathrm{S} 1}$ Coefficient based on the shape of the pier nose (table 7).

$\mathrm{K}_{\mathrm{S} 2}$ Coefficient based on the shape of the pier nose; 1.0 for cylindrical piers and 1.4 for rectangular piers.

$\mathrm{K}_{\mathrm{y}} \quad$ Coefficient for flow depth. 
$\mathrm{K}_{1} \quad$ Coefficient based on the shape of the pier nose; 1.1 for square-nosed piers, 1.0 for circular- or round-nosed piers, 0.9 for sharp-nosed piers, and 1.0 for a group of piers.

$\mathrm{K}_{2}$ Coefficient based on the ratio of the pier length $(L)$ to pier width $(b)$ and the angle of the approach flow refcrenced to the bridge pier:

\begin{tabular}{cccc}
\hline Angle & $L / b=4$ & $L / b=8$ & $L / b=12$ \\
\hline 0 & 1.0 & 1.0 & 1.0 \\
15 & 1.5 & 2.0 & 2.5 \\
30 & 2.0 & 2.75 & 3.5 \\
45 & 2.3 & 3.3 & 4.3 \\
90 & 2.5 & 3.9 & 5.0 \\
\hline
\end{tabular}

$\mathrm{K}_{3} \quad$ Coefficient based on the bed conditions:

\begin{tabular}{lcl}
\hline Bed condition & Dune height & $K_{3}$ \\
\hline Clear-water scour & N/A & 1.1 \\
Plane bed and antidune flow & N/A & 1.1 \\
Small dunes & $2-10 \mathrm{ft}$ & 1.1 \\
Medium dunes & $10-30 \mathrm{ft}$ & $1.1-1.2$ \\
Large dunes & $>30 \mathrm{ft}$ & 1.3 \\
\hline
\end{tabular}

$\mathrm{K}_{\alpha \mathrm{L}}$ Coefficient based on flow alignment, (Fig. 39).

$\mathrm{k}_{\mathrm{q}}$ Conveyance, of the subsection of the approach section, of the discharge that can pass through the bridge opening without contraction, cubic feet per second.

$\mathrm{k}_{\mathrm{a}}$ Total conveyance of the of the approach cross section, cubic feet per second.

L Length of the bridge pier, feet.

m Channel contraction ratio.

q Discharge per unit width just upstream from the pier, cubic feet per second per foot.

Q Discharge, cubic feet per second.

$\boldsymbol{R}_{\mathrm{p}} \quad$ Pier Reynolds number, defined as, $\frac{\mathrm{V}_{\mathrm{o}} \mathrm{b}}{\mathrm{v}}$.

$u_{*_{c}} \quad$ Critical shear velocity, feet per second.

V Average velocity of the section, feet per second. 
$\mathrm{V}_{\mathrm{a}} \quad$ Critical velocity of the armor layer, feet per second.

$\mathrm{V}_{\mathrm{c}} \quad$ Critical velocity, feet per second.

$V_{c a}$ Critical velocity of the armor layer using $d_{50 a}$, feet per second.

$\mathrm{V}_{\mathrm{o}} \quad$ Velocity of the approach flow just upstream from the bridge pier, feet per second.

$y_{0} \quad$ Depth of flow just upstream from the bridge pier, excluding local scour, feet.

$y_{p} \quad$ Depth of flow at the bridge pier, including local pier scour, feet.

$y_{r} \quad$ Regime depth of flow, defined as $\left(\frac{q^{2}}{f_{b}}\right)^{1 / 3}$, feet.

$y_{s} \quad$ Depth of pier scour below the ambient bed, feet.

$v \quad$ Kinematic viscosity of water, feet squared per second.

$\alpha \quad$ Angle of the approach flow referenced to the bridge pier (attack angle), in degrees.

$\phi \quad$ A coefficient based on the shape of the pier nose; 1.3 for square-nosed piers, 1.0 for round-nosed piers, 0.7 for sharp-nosed piers.

$\sigma \quad$ Geometric standard deviation of particle-size distribution, defined as $\sqrt{\frac{d_{84}}{d_{16}}}$. 


\title{
Evaluation of Bridge-Scour Data at Selected Sites in Ohio
}

\author{
By K. Scott Jackson
}

\section{ABSTRACT}

Scour data collected during 1989-94 were evaluated to determine whether pier scour and contraction scour occurred at 22 bridge sites in Ohio. Pier-scour depths computed from selected pier-scour prediction equations were compared with measured pier-scour depths, and the accuracy of the prediction equations were evaluated. Observed pier-scour relations were compared to relations developed through laboratory research. Mean streambed elevations were evaluated to determine the depth of contraction scour. Channel stability was assessed by use of mean streambed elevations at the approach section. Ground-penetrating radar was used at all sites to investigate the presence of historical scour.

Pier scour was observed in 45 of 47 scour measurements made during floods; 84 cases of pier scour were documented, 83 at solid-wall piers and 1 at a capped-pile type pier. Estimated recurrence intervals for 27 of the 35 measured streamflows, all on unregulated streams, were less than 2 years.

Seventeen pier-scour prediction equations were evaluated. The Froehlich Design equation was found to most closely meet the "best design equation" criteria for all 84 cases of the observed data. The Larras equation was found to be the best design equation for the observed data where approach-flow attack angles were 10 degrees or less.

Observed pier-scour depths and flow depths ranged from 0.5 to 6.1 feet and 3.0 to 19.8 feet, respectively. All pier-scour depths were less than 2.4 times the corresponding pier width. Selected factors were normalized by dividing by effective pier width. LOWESS curves were developed using the 84 cases of observed pier scour. Normalized scour depth increased with normalized flow depth; however, the rate of increase appeared to lessen as normalized flow depth exceeded 2.5. Normalized scour depths increased rapidly as flow intensity approached the threshold value of 1 and then decreased as flow intensities exceeded this threshold. Normalized scour depth was found to increase with Froude number, and a steeper slope was evident for Froude numbers exceeding 0.2. Normalized scour depth was found to increase with median grain size up to about 10 millimeters for bed material near the pier, then decrease for median grain sizes greater than 10 millimeters. Normalized scour depth was also found to decrease as sediment gradation of bed material near the pier increased.

The observed pier-scour relations determined from the field measurements tend to support conclusions by previous researchers of streambed scour, except for the previous finding that normalized scour depth decreases consistently with increasing median grain size. Possible factors that may have influenced the observed trends in the relation between normalized scour depth and median grain size in this study are cohesion and scour measurements made at nonequilibrium conditions. LOWESS curves were developed for 45 of 84 cases of observed pier scour where approach-flow attack angles were less than or equal to 10 degrees. These curves were visually compared to LOWESS curves developed from all observations of pier scour. For three relations, differences in the trends of the LOWESS curves were of sufficient magnitude to warrant discussion. 
Contraction scour was observed in 4 of the 47 scour measurements and ranged from 0.8 to 2.3 feet in depth. Analysis of annual mean streambed approach-section elevations indicated that approach sections were generally stable at 18 of the 22 sites. Ground-penetrating radar, a geophysical method that enables subsurface exploration of the streambed when conditions are favorable, was used at all sites to determine whether historical scour had occurred. Results of the ground-penetrating radar surveys at 20 sites in 1990 indicated the presence of historical scour surfaces at 5 sites. At four of the five sites showing evidence of possible historical scour, differences between the estimated depth of historical scour and the maximum observed scour were within \pm 1 foot, and at the other site, the depth of historical scour was 3 feet deeper than the maximum scour measured.

\section{INTRODUCTION}

Scour, defined here to mean the erosion of a streambed during floods and the resultant undermining of bridge foundations, is the most common cause of bridge failure in the United States (Murillo, 1987). Recent catastrophic bridge failures in the United States involving the loss of life and attributed wholly or partly to scour include those at the U.S. Route 51 bridge crossing of the Hatchie River in Tennessee (1989), the New York Thruway-Interstate 90 bridge spanning Schoharie Creek near Amsterdam, New York (1987), and the Interstate 5 bridge over the Arroyo Pasajero in California (1995) (Lagasse and others, 1995). Additionally, 17 bridges were damaged or destroyed by scour in New York and New England in 1987, and 73 bridges were destroyed by flooding in Pennsylvania, Virginia, and West Virginia in 1985 (Richardson and others, 1993). The geographic diversity of these locations indicates that scour can be a serious problem in many parts of the Nation.

Bridges over waterways are generally designed for a long service life, typically 50 to 100 years. Therefore, these structures are statistically likely to be exposed to some extreme floods during their anticipated period of service. The cost to the public for the design, construction, and maintenance of bridges is significant. Lagasse and others (1995) state, "Based upon data from the 1980's, a conservative estimate of direct federal expenditures for bridge-restoration projects nationally is about $\$ 20$ million annually." The Federal Highway Administration (FHWA) estimates that about 577,000 bridges are included in the National Bridge Inventory and that about 84 percent of these bridges span waterways (Richardson and others, 1993). The Ohio Department of Transportation (ODOT) estimates that there are slightly less than 43,000 bridges in Ohio, making Ohio's the second largest statewide inventory of bridges in the Nation (Purpura, 1994). Although bridge design, construction, and maintenance costs are considerable, the cost of a bridge failure is higher. The FHWA estimates that the total cost of a bridge failure can easily be 2 to 10 times the cost of the bridge itself (Richardson and others, 1993).

The total scour that may occur at a highway structure consists of three scour processes (components) that may act alone or in combination upon areas of the streambed:

Local scour - the erosion of streambed materials in the vicinity of bridge piers and (or) abutments caused by local accelerations and (or) disturbances in the flow.

Contraction scour - the erosion of streambed materials within a natural or manmade contrac-

tion of the stream channel due to an increase in flow velocity and bed shear stress.

General channel scour - progressive, nonlocalized degradation of the streambed as might be caused by natural geomorphic processes or changes in channel controls. This type of scour may occur in a channel reach even where no bridge is present.

The accurate estimation of scour is important in helping bridge designers to produce safe and cost-effective bridges. Numerous scour-prediction equations have been published over the years. According to Mueller and others (1994), more than 35 pier-scour equations, a significant number of 
abutment-scour equations, and several contraction-scour equations are available in the literature. Nearly all of these equations are empirical equations and methods for the prediction of scour derived from laboratory flume studies. The predicted depths of scour estimated from laboratory-produced equations, for the same conditions, are quite varied (Anderson, 1974) and therefore have been inconclusive; the result has been uncertainty among bridge designers about which method is most accurate for their design conditions.

The magnitude of local scour around piers is influenced by several factors that include pier geometry, flow attributes, and bed-material characteristics. It is the dynamic interaction of these factors that constitute the complex local-scour process and make pier-scour prediction difficult. To improve the understanding of the pier-scour process and predictive techniques, laboratory studies have typically been designed to investigate the effect of changes in a specific factor while holding other factors constant over the range of the experiments. Although such studies have furthered the understanding of the pier-scour process, they generally have not addressed the complexity associated with multifactor interactions; consequently, field-based studies are needed. Historically, few scour and pertinent hydraulic data have been collected in the field during floods to verify the applicability and accuracy of design procedures for the range of streambed materials, streamflow conditions, and bridge designs in the United States (Richardson and others, 1993). Researchers have realized the complex nature of the scour process for some time. Melville (1975) states, “. . . because scour in the field is generally orders of magnitude more complicated than its laboratory counterpart ... it has been found necessary to over-simplify the phenomenon in order to obtain a laboratory model for research purposes."

Collection of scour-related data at bridge sites during high-flow conditions can be difficult and dangerous. Maximum scour is typically reached at or near the peak flow, when flow velocity and the resultant bed shear-stress forces are generally the greatest. Therefore, collection of scour data at bridges during floods requires (1) measurement techniques that will ensure data of sufficient accuracy and quantity, (2) equipment that can withstand the harsh sampling environment, and (3) personnel familiar with high-flow data-collection techniques who can be rapidly mobilized and dispatched to bridge sites.

Scour holes may refill when sediments in transport during a flood accumulate as the flooding subsides. This refilling process, if it occurs, complicates determination of the maximum depth of scour from streambed sections measured after the flood. Recent investigators (Gorin and Haeni, 1989; Mueller and others, 1994) have had success in using various geophysical methods to detect the presence of infilling.

Before 1989, no efforts had been made in Ohio to collect scour data during floods and to assess the applicability of published pier-scour prediction equations by comparisons with field data. In 1989, the U.S. Geological Survey (USGS), in cooperation with the Ohio Department of Transportation and the U.S. Department of Transportation, Federal Highway Administration, began a study to collect streambed-scour data at selected bridge sites in Ohio. A primary goal of the study, assuming flooding conditions were conducive, was to obtain a total of 50 high-flow scour measurements within a 5-year datacollection period beginning January 1990 and ending December 1994.

\section{Purpose and Scope}

This report describes the results of the study to collect scour and associated hydraulic data at bridges in Ohio and to compare measured scour at piers with that determined from selected pier-scour prediction equations. Measured pier scour is also evaluated in terms of selected factors, and those evaluations are compared to observations reported in the literature. Contraction scour and approach-channel stability data at the field sites also are assessed. Scour data collected by use of ground-penetrating radar are evaluated to determine whether historical scour had occurred. The scour data collected for this study 
will be included in a National scour data base as part of an ongoing study (Landers and others, 1996) by the USGS and the U.S. Department of Transportation, Federal Highway Administration.

\section{Acknowledgments}

The author thanks the personnel of the Ohio Department of Transportation (ODOT) for their assistance and support, especially William J. Krouse for his cooperation on numerous parts of this investigation. ODOT's District personnel were particularly helpful in providing crews and equipment for the removal of woody debris at numerous study sites during the study. The author is grateful to Mark N. Landers and David S. Mueller of the U.S. Geological Survey (USGS) for their many technical reviews and discussions. The author also appreciates the contribution of Rodney A. Sheets of the USGS for his efforts and guidance in the collection and interpretation of scour data by use of geophysical techniques. Finally, the author thanks the data-collection personnel of USGS Ohio District and Miami Conservancy District for their support in the collection of high-flow scour measurements. The collection of scour data during floods is a difficult and rigorous endeavor; without the dedication and persistence of the individuals who collected the data, this study would not have been possible.

\section{PREVIOUS PIER-SCOUR RESEARCH}

In this report, selected pier-scour relations determined from field-measured data collected during this investigation are compared to identical relations described in the scour research literature. Therefore, an abbreviated summary of previous pier-scour research is given here. Previous research has established that the following factors can affect the depth of pier scour.

Pier width. Pier-scour depth has been shown to increase as pier width increases (Richardson and others, 1993). Melville and Sutherland (1988) reported that the greatest possible scour depth at a cylindrical pier is 2.4 times the pier diameter $(b)$.

Pier alignment. A pier not aligned with the flow presents an effectively wider obstruction (flow width) and will result in an increase in scour depth. Through laboratory research, Laursen and Toch (1956) developed a correction coefficient to account for the increase in scour depth as flow angle (angle of attack) increased. The coefficient is dependent on the length and width of a pier and is used in predictive equations developed by other researchers (Richardson and others, 1993; Melville and Sutherland, 1988). The location of the scour hole also changes as the angle of the approaching-flow streamlines deviate from the alignment of the pier. Laursen and Toch (1956) demonstrated that as the flow streamlines become more skewed to the pier, the point of deepest scour migrates from the upstream face of the pier towards a location along the side of the pier.

Flow depth. When the approach flow meets the pier face, it generally separates vertically: An upflow is directed towards the water surface (the surface roller at the water surface), and a downflow is directed towards the streambed. These two flows help create rotational flow areas near the surface and the streambed. Ettema (1980) stated that "The flow in the roller rotates in a reverse sense to the rotation of the flow in the horseshoe vortex" and that for shallow flow depths "The surface roller or 'bow wave' formed at the free surface around the pier, interferes with the formation of the horseshoe vortex and the downflow into the scour hole." (The horseshoe vortex is the term commonly used by scour researchers to describe the three-dimensional flow field created near the pier and the streambed, which is primarily responsible for the erosion of the streambed materials.) 
The research has been inconclusive regarding how flow depth relates to pier-scour depth. Laursen and Toch (1956) determined that scour depth increases with flow depth. For cylindrical piers, Breusers and others (1977) found that flow depth has a negligible influence on scour depth when the ratio of flow depth to pier width $\left(y_{o} / b\right)$ exceeds 1 . Richardson and others (1993) stated that "An increase in flow depth can increase scour depth by a factor of 2 or greater for piers." Melville and Sutherland (1988) stated that scour depth increases with flow depth as long as the ratio of flow depth to pier width is less than about 3; above this value, flow depth has no effect.

Flow velocity. Flow velocity also has an effect on pier-scour depth. From analysis based on data from several investigations, Melville (1984) suggests that normalized scour depth $\left(y_{s} / b_{e}\right)$, when plotted as a function of flow intensity $\left(V_{o} / V_{c}\right)$, exhibits two scour maximums as shown in figure 1 . The first maximum occurs at the transition between clear-water and live-bed scour. (Clear-water scour occurs when a negligible amount of bed material is being transported into the zone of local scour. Live-bed scour occurs when bed material is being transported into and out of the zone of local scour from an upstream source.) Melville explains for the first maximum that "With clear-water scour, the equilibrium scour depth is approached asymptotically when the flow is no longer capable of removing bed sediments from the (scour) hole." The clear-water/live-bed scour transition occurs at threshold sedimenttransport conditions (when flow intensity is equal to 1). As flow intensity increases above 1 (live-bed scour conditions), scour depth initially is reduced between $V_{o} / V_{c}$ values of about 1 and 2, then scour depth increases again to a second maximum.

Froude number. Flow is typically classified in hydraulics by use of the Froude number $(\boldsymbol{F})$, an indicator of the ratio of inertial to gravitational forces. Froude numbers less than 1, where the gravitational forces dominate, are classified as subcritical. Froude numbers greater than 1 , where inertial forces exceed gravitational forces, are classified as supercritical. As previously stated, flow velocity has an effect on pier-scour depth. Therefore, the Froude number, a function of velocity, also may influence pier-scour depth. Several scour researchers (Chitale, 1962; Richardson and others, 1993; Froehlich, 1988) have found the Froude number to be a significant factor and have included it in their pier-scour prediction equations. Richardson and others (1993) stated that "There is a high probability that scour is affected by whether the flow is subcritical or supercritical" and "most (scour) research and data are for subcritical flow."

Sediment size. Bed-material size affects the initiation and rate of sediment transport into and out of the scour hole. Research by laboratory investigators indicates that equilibrium pier-scour depth is reduced as bed-material size increases (Chiew and Melville, 1987; Ettema, 1980; Melville and Sutherland, 1988; Raudkivi and Ettema, 1983). Chiew (1984), for live-bed data, and Ettema (1980), for clear-water data, found that normalized scour depth is a function of the ratio between pier width and median grain size diameter $\left(b / d_{50}\right)$. They concluded that scour depth decreases with decreasing values of $b / d_{50}$ and is independent of $b / d_{50}$ when $b / d_{50}$ is greater than or equal to 50 .

Most scour-prediction equations do not directly account for the effect of sediment size on scour depth. However, sediment size is a factor in some predictive equations. Melville and Sutherland (1988) proposed a sediment-size factor, $K_{d}$, computed as $0.57 \log \left(2.24\left(b / d_{50}\right)\right)$ where $b / d_{50}$ is less than 25 , and $K_{d}$ equals 1 where $b / d_{50}$ is greater than 25 . Froehlich (1988) used the ratio of pier width to the median grain size $\left(b / d_{50}\right)$ in a regression analysis on scour variables and determined an exponent of 0.08 for this ratio $\left(b / d_{50} 0.08\right)$.

Sediment gradation. The geometric standard deviation of particle-size distribution $(\sigma)$ is a measure of the variation of sediment gradation. Previous scour research indicates that scour depth decreases as sediment gradation increases (Ettema, 1980; Raudkivi and Ettema, 1977; Raudkivi and Ettema, 1983; Baker, 1986). For clear-water scour conditions, Ettema (1980) found that equilibrium scour depth was reduced about 80 percent when sediment gradation was varied from uniform sediments to nonuniform 


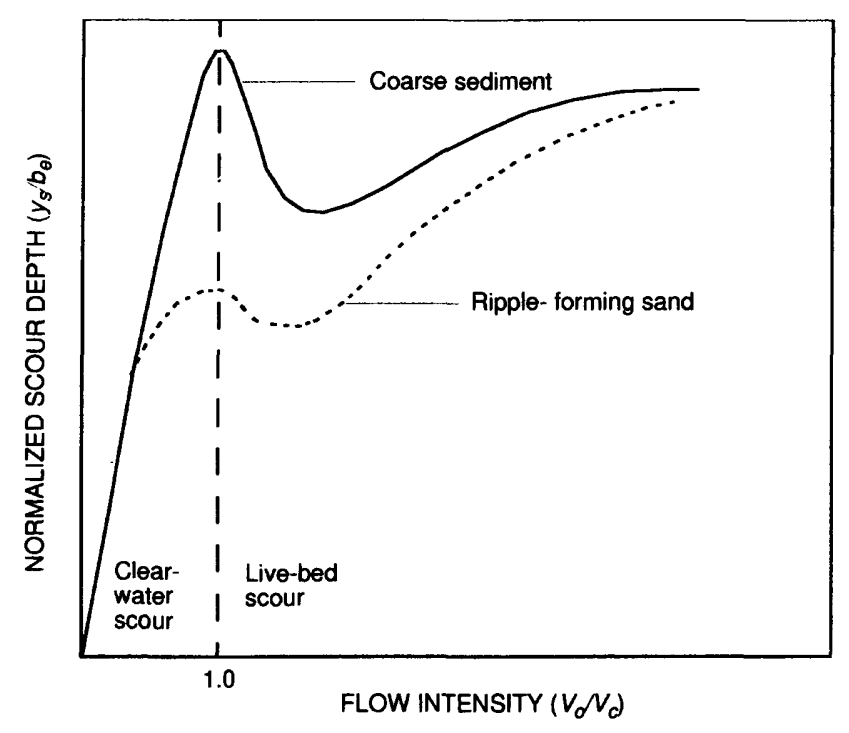

Figure 1. Relation of normalized scour depth to flow intensity at cylindrical piers in uniform sediments (from Melville, 1984).

sediments. Ettema stated that bed sediments with $\sigma$ values of less than about 1.5 may be considered virtually uniform in particle size. Melville and Sutherland (1988) discussed the results of a study by Baker (1986) on the relation between sediment gradation and scour depth for live-bed scour conditions; in that study, equilibrium scour depth also was reduced as sediment gradation increased, and the influence of sediment gradation was found to decrease as velocity increased. Melville and Sutherland also indicated that the influence of gradation on scour depth was not as great for live-bed conditions as for clear-water conditions.

\section{SELECTION OF STUDY SITES}

A detailed site-selection process was adopted for this investigation to maximize the chances of meaningful data collection. The "Pilot Study for Collection of Bridge-Scour Data" (Jarrett and Boyle, 1986), completed by the USGS in cooperation with FHWA, established guidelines and recommendations for the collection of scour data at bridge sites during high flows. These guidelines were reviewed for applicability to Ohio, and several of the recommended criteria were adopted for this study. The following criteria, which are not necessarily comprehensive but generally describe ideal measurement sites, were established for the selection of 20 Ohio study sites:

1. Drainage basin sizes should be representative of basins in Ohio.

2. Sites should represent various geographical areas of the State.

3. At least half of the sites should be at or near a streamflow-gaging station instrumented to monitor rapid changes of stage in the streams. Preferably, the gaging stations should be equipped with satellite or other types of telemetry for the real-time monitoring of streamflow conditions.

4. Sites should represent the various types of streambed materials found in Ohio that are prone to scour. 


\begin{tabular}{|c|c|c|c|c|}
\hline $\begin{array}{c}\text { Site } \\
\text { number }\end{array}$ & $\begin{array}{l}\text { U.S. Geological } \\
\text { Survey } \\
\text { station number }\end{array}$ & Site name and location & $\begin{array}{c}\text { Drainage } \\
\text { area } \\
\text { (square } \\
\text { miles) }\end{array}$ & $\begin{array}{l}\text { Slope In vicinity } \\
\text { (foot per foot) }\end{array}$ \\
\hline 1 & 404037084155200 & State Routc 198 over Auglaize River near Wapakoneta & 200 & 0.0006 \\
\hline 2 & 393549082324700 & U.S. Route 33 over Clear Creek near Rockbridge & 91.8 & .0019 \\
\hline 3 & 414308081134101 & State Route 84 over Grand River near Painesville & 685 & .00109 \\
\hline 4 & 392340084341700 & State Route 128 over Great Miami River at Hamilton & 3,630 & .00049 \\
\hline 5 & 400150084111300 & State Route 41 over Great Miami River at Troy & 927 & .00023 \\
\hline 6 & 392731082142400 & State Route 278 over Hocking River at Nelsonville & 576 & .00038 \\
\hline 7 & 410120083063501 & State Route 67 over Honey Creek at Melmore & 149 & .0014 \\
\hline 8 & 402941081591200 & County Road 621 over Killbuck Creek at Killbuck & 462 & .00023 \\
\hline 9 & 392424084060400 & State Route 350 over Little Miami River at Fort Ancient & 675 & .00084 \\
\hline 10 & 400627083475701 & U.S. Route 36 over Mad River near Urbana & 162 & .00136 \\
\hline 11 & 394410083561000 & U.S. Route 68 over Massies Creek at Oldtown & 84.4 & .00357 \\
\hline 12 & 411536084331400 & U.S. Route 127 over Maumee River near Sherwood & 2,276 & .00022 \\
\hline 13 & 404257084081500 & Township Road 122 over Ottawa River at Lima & 130 & .00144 \\
\hline 14 & 391520082461200 & U.S. Route 50 over Salt Creek near Londonderry & 286 & .00082 \\
\hline 15 & 39203108258270 & State Route 159 over Scioto River at Chillicothe & 3,849 & .00035 \\
\hline 16 & 402902083112800 & State Route 4 over Scioto River near Prospect & 528 & .00008 \\
\hline 17 & 403515081312401 & State Route 250 over Sugar Creek at Strasburg & 311 & .00087 \\
\hline 18 & 392115084074600 & State Route 22 over Todd Fork at Morrrow & 262 & .00179 \\
\hline 19 & 40471508131220 & Walnut Road over Tuscarawas River at Massillon & 513 & .00008 \\
\hline 20 & 401933081304100 & County Road 14 over Tuscarawas River near Port Washington & 2,400 & .00047 \\
\hline 21 & 400710082081001 & State Route 16 over Wakatomika Creek at Frazeysburg & 140 & .00062 \\
\hline 22 & 394609082544200 & County Road 17 over Walnut Creek near Ashville & 216 & .00068 \\
\hline
\end{tabular}

5. Bedrock should not be exposed in the vicinity of the bridge, and piers should not be protected with riprap.

6. Bridge piers (for example, capped-pile, drilled shaft-column, and solid-wall types) should be of various simple shapes, and pier faces should be near the upstream side of the bridge. Piers should not constrict the cross-sectional flow area of the bridge opening by more than 10 percent.

7. Flow should be parallel to the long axis of the piers. (One site where piers were angled to the flow at greater than 10 degrees was selected intentionally).

8. The site should not be prone to accumulation of debris on the piers.

9. The channel should be uniform upstream and downstream from the bridge site.

10. The site should be accessible during high flows.

11. Bridges should be wide enough to provide safe workspace for a two-person crew and the measurement equipment.

12. Contraction of the channel at the bridge site should be minimal during floods. 
To aid in site selection, personnel from ODOT district offices provided information on sites where scour problems were thought or known to exist. USGS personnel visited more than 400 bridges statewide and rated each site for its suitability as a scour-measurement site. On the basis of (1) the site-selection criteria, (2) ODOT information, and (3) field-reconnaissance ratings, 31 bridges were selected as candidates for scour-measurement sites. After ODOT and USGS reviews, 11 of the 31 candidate sites were dropped, leaving a network of 20 scour-measurement sites. The ODOT Bridge Bureau requested that at least one of the 20 sites selected be a site where the flow was substantially skewed to the piers.

After the data-collection phase of the study had begun, the 20-station network was expanded at the request of ODOT to include 2 bridges with multiple-column capped-pile piers. This type of bridge-pier design is common in Ohio. The locations of the 22 scour-measurement sites are shown in figure 2.

Site number (the site numbering correlates to alphabetical listing by stream name), USGS station number, drainage area, and the channel slope in the vicinity of the study site for the 22 scourmeasurement sites are listed in table 1. Drainage area for the 22 sites ranged from 84 to $3,849 \mathrm{mi}^{2}$.

\section{STUDY METHODS}

Historically, scour researchers have used various methods to analyze scour data. Landers and Mueller (1993) reported that the various methods used to compute scour depths can produce results that differ by as much as 100 percent. Field measurements of scour are made under dynamic conditions (that is, varying flow depth and velocity) at sites in natural channels where sediments typically are nonuniform. The methods used to collect scour data in the field and analyze these data are important and must be clearly stated because they influence the results of an investigation. The methods used to collect data and compute of pier- and contraction-scour depth in this study are described in the paragraphs that follow.

\section{Data Collection}

Scour data were obtained from field surveys and streamflow measurements at the scour-measurement sites. Streambed cross sections were surveyed to provide a baseline from which to monitor changes in channel conditions. Bed-material samples were obtained to determine particle-size distribution. During floods, streamflow measurements and water-surface elevation data were collected for pier- and contraction-scour analyses. Geophysical data were collected to investigate the presence of historical scour.

During the data-collection period (1989-94), attempts were made to make 62 scour measurements at 21 of the 22 previously selected sites ${ }^{1}$ established for data collection. Of these -attempts, 47 provided sufficient data for scour analysis. Pier scour was observed, for at least one pier per site, in 45 of the 47 measurements, and contraction scour was evident in 4 of the measurements. The total number of measurements made at a site varied from site to site. One measurement was made at six of the study sites, two were made at six sites, three at seven sites, and four at two sites providing a total of 47 measurements.

\footnotetext{
'No scour measurements were made at Walnut Road over Tuscarawas River at Massillon. This site was dropped from the study in late summer 1992 because riprap was placed at the pier footings, rendering the site useless for scour measurement.
} 
Woody debris accumulated repeatedly at many sites during the data-collection period, which prevented the use of sounding weights for collection of water-depth data in the vicinity of the pier face. During annual low-flow data-collection visits, debris piles that had accumulated at pier faces throughout the year were removed. Even with these debris-removal efforts, the collection of debris on pier faces during floods was a persistent problem in collection of scour data. The presence of debris piles at bridge piers was the most prevalent reason for failed scour-measurement attempts. When debris was present, however, fathometers were sometimes used successfully for depth sounding. Fathometers were especially useful when submerged debris was not very dense. Generally, one or two logs (estimated to be $2 \mathrm{ft}$ or less in diameter) trapped below the water surface at the face of the pier did not prohibit the use of a fathometer to measure water depths.

\section{Annual Low-Flow Data}

During the data-collection period (1989-94), data were collected annually at each scourmeasurement site during low flow (generally during June through October). These data provide a baseline from which to monitor changes in stream-channel shape, elevation, and scour-related characteristics (such as streambed degradation or aggradation and bed-material particle-size distribution).

Streambed cross sections were surveyed at the approach (uncontracted) section and the bridge (contracted) section by means of an electronic theodolite (total station). The bridge section was surveyed along the upstream edge of the bridge opening. Typically, 25 to 50 ground-point readings were obtained to define the primary breaks in slope at each cross section surveyed. During surveys of the bridge section, a greater density of readings was obtained near the piers to better define the shape of existing scour holes. Reference marks, reference points, staff gages, and tape-down points at each site also were surveyed annually. Surveyed elevations are referenced to sea level.

Bed-material samples were collected annually at each site and analyzed to determine particle-size distribution. Samples represent material from the streambed surface and slightly below the bed surface. Samples at each pier within or near the main channel consisted of material obtained immediately upstream from a pier and, if a scour hole was present, from within the scour hole. Composited bridgeand approach-section bed-material samples also were collected at approximately equally spaced intervals (typically at three to five locations) along the cross section of the stream channel. Bridgesection composite samples were collected along the upstream side of the bridge. Approach-section composite samples were collected along the approach section at each site during the last 2 years of fieldwork only.

Bed-material samples were collected by use of one of the following sampling devices: (1) a 100-pound US BM-54 bed-material sampler suspended by either cable or rope (Guy and Norman, 1970), (2) a hand-held bed-material sampler, produced for this investigation, of a design similar to that of samplers developed during previous USGS scour investigations (Norman, 1975; Jarrett and Boyle, 1986), or (3) a plastic sample container (typically used to transport and store the samples) to collect samples at pier locations that were outside of the low-water channel. The hand-held sampler was constructed of a 12-in. long 2-in. diameter steel pipe welded closed at one end. A steel-rod handle about $6 \mathrm{ft}$ in length was attached to the pipe to facilitate the collection of samples. The plastic sample container could hold a maximum of $0.033 \mathrm{ft}^{3}$ of sample material and typically was filled to about 80 percent of its total capacity. All bed-material samples were analyzed for particle-size distribution by weight at the ODOT soils laboratory. 

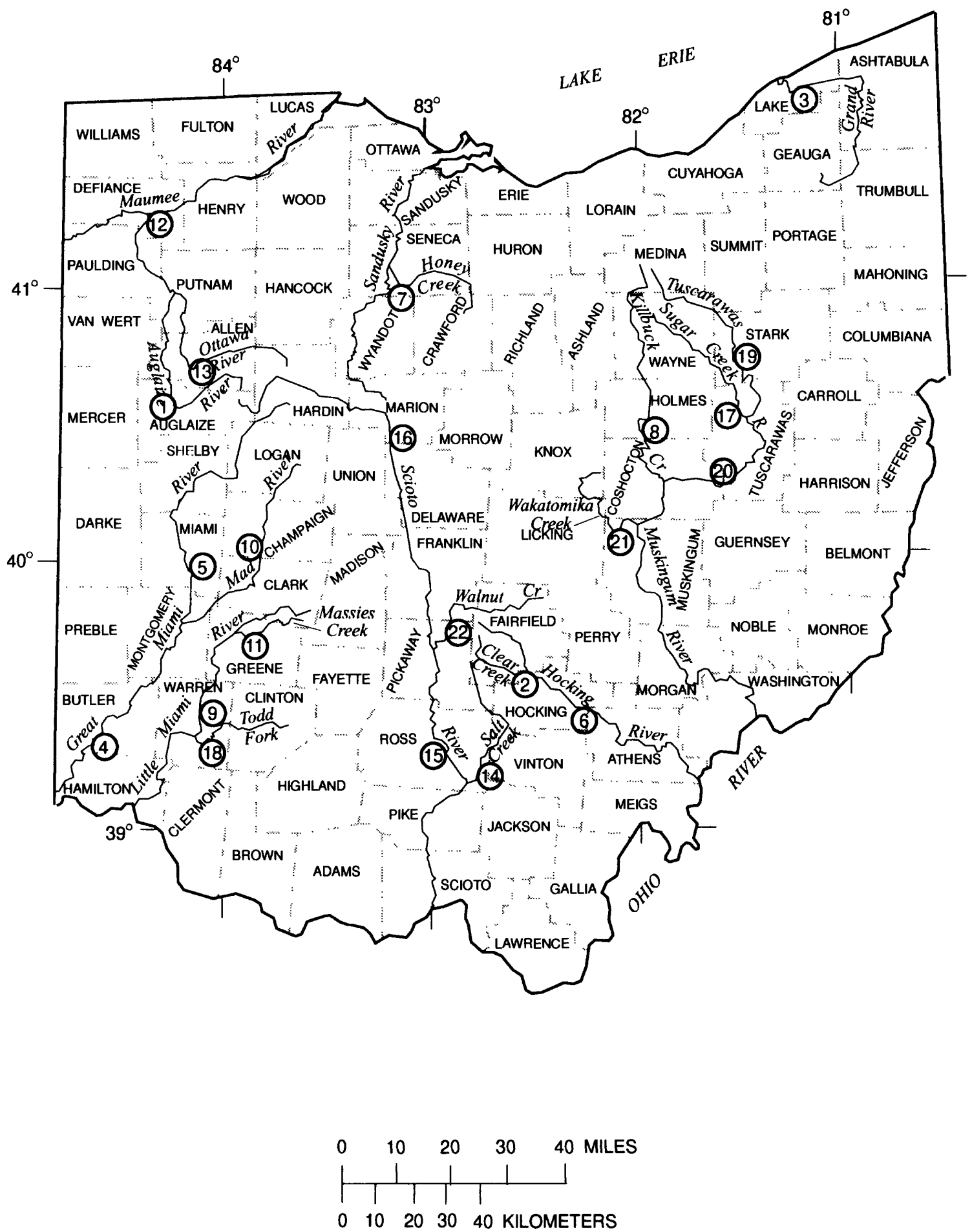

Figure 2. Location of study sites. 


\section{EXPLANATION}

SITE

NUMBER

SITE LOCATION

IN OHIO

(1) STATE ROUTE 198 OVER AUGLAIZE RIVER NEAR WAPAKONETA

(2) U.S. ROUTE 33 OVER CLEAR CREEK NEAR ROCKBRIDGE

(3) STATE ROUTE 84 OVER GRAND RIVER NEAR PAINESVILLE

(4) STATE ROUTE 128 OVER GREAT MIAMI RIVER AT HAMILTON

(5) STATE ROUTE 41 OVER GREAT MIAMI RIVER AT TROY

(6) STATE ROUTE 278 OVER HOCKING RIVER AT NELSONVILLE

(7) STATE ROUTE 67 OVER HONEY CREEK AT MELMORE

(8) COUNTY ROAD 621 OVER KILLBUCK CREEK AT KILLBUCK

(9) STATE ROUTE 350 OVER LITTLE MIAMI RIVER NEAR FORT ANCIENT

(10) U.S. ROUTE 36 OVER MAD RIVER NEAR URBANA

(11) U.S. ROUTE 68 OVER MASSIES CREEK NEAR OLDTOWN

(12) U.S. ROUTE 127 OVER MAUMEE RIVER NEAR SHERWOOD

(13) TOWNSHIP ROAD 122 OVER OTTAWA RIVER AT LIMA

(14) U.S. ROUTE 50 OVER SALT CREEK NEAR LONDONDERRY

(15) STATE ROUTE 159 OVER SCIOTO RIVER AT CHILLICOTHE

(16) STATE ROUTE 4 OVER SCIOTO RIVER NEAR PROSPECT

(17) STATE ROUTE 250 OVER SUGAR CREEK NEAR STRASBURG

(18) STATE ROUTE 22 OVER TODD FORK AT MORROW

(19) WALNUT ROAD OVER TUSCARAWAS RIVER AT MASSILLON

(20) COUNTY ROAD 14 OVER TUSCARAWAS RIVER NEAR PORT WASHINGTON

(21) STATE ROUTE 16 OVER WAKATOMIKA CREEK NEAR FRAZEYSBURG

22 COUNTY ROAD 17 OVER WALNUT CREEK NEAR ASHVILLE

Figure 2. Location of study sites--Continued. 


\section{High-Flow Scour Data}

Attempts were made to collect high-flow scour data as close to the peak flow as possible. Nearreal-time weather and stream-gage data were used to monitor the dynamics of storm movement, spatial distribution and temporal intensity of rainfall, and stream stage. The National Weather Service high-resolution radar data (hourly rainfall pattern and intensity) were used to assist in determining which areas of the State had received or might receive significant rainfall. These radar data were particularly useful for tracking storms that affected the State during the late evening and early morning. USGS stream gages with telemetry provided near-real-time stage data that were used to assess the severity of the flooding and to establish measurement priorities.

Data collected at scour-measurement sites during high flow included one or more standard streamflow measurements (Rantz and others, 1982) along the upstream side of the bridge. Typically, the number of sections (verticals) obtained during a streamflow measurement ranged from 25 to 35 , but the number was reduced when the stage was changing rapidly. Velocity measurements were usually made at 0.2 and 0.8 times the water depth from the water surface. Where the depth was less than $5 \mathrm{ft}$ (common at the verticals near the edges of measurement section), velocity measurements were obtained at 0.6 times the water depth from the water surface. On some occasions, when flow and stage were not changing rapidly, velocity measurements near the sides of piers were obtained during the streamflow measurement.

Typically, after a discharge measurement was completed, additional depth soundings were made along the upstream side of the bridge. Supplemental depth soundings were made, at 1- $\mathrm{ft}$ intervals, typically for about $5 \mathrm{ft}$ in both directions from the centerline of each pier face. These supplemental depth soundings helped to improve definition of the streambed geometry in the vicinity of a pier. Stream depth and position in the vertical were measured by the use of a cable-suspended Columbus sounding weight and a B-56 sounding reel, mounted on a four-wheel type-A base. A fathometer was used at some sites to obtain additional sounding data. The fathometer's 192-kHz narrow-beam transducer ( 8 degree) was attached to a Columbus weight suspended a known distance below the water surface. The water-depth data measured by the fathometer was recorded by a paperchart recorder. Because the water-surface elevation was known, the streambed elevation could be computed from the sounding data collected with the fathometer. As the four-wheel base apparatus (transducer) was moved along the bridge, the fathometer chart was marked to denote specific points of interest during measurements, such as the sides and centerline of a pier and the bridge stations that were previously established along the bridge railing or parapet. Velocity measurements were made by use of a Price type AA current meter, also suspended on the cable.

Measurements of distance to the water surface were obtained from the tape-down point (at a known elevation) on the upstream side of the bridge before, during, and after the streamflow measurement. These data were subsequently converted to water-surface elevations. Additionally, if flood conditions permitted, attempts were made to establish the water-surface elevation (or set highwater marks to be surveyed at a later date) at the approach section to define the water-surface slope between the approach and bridge sections. Water temperature also was recorded, and photographs were taken of the flow conditions at the bridge, around various piers, and along the channel upstream and downstream from the bridge.

\section{Geophysical Data}

Geophysical methods have been used to investigate scour around bridges and locate evidence of scour holes or surfaces that may have refilled with sediment (Gorin and Haeni, 1989; Crumrine, 1991; Haeni and Placzek, 1991; Haeni, 1992; Haeni and others, 1992; Placzek and others, 1993; 
Mueller and others, 1994). Geophysical equipment used in scour studies transmits a "wave" that noninvasively penetrates the substrate beneath the water column, reflects off of a physical or electrical interface, and returns to a receiver.

Several geophysical methods were tested during low flow in summer 1990, including black and white fathometer, color fathometer, continuous seismic reflection, and ground-penetrating radar. This combination of methods takes advantage of different frequency characteristics that might allow for different subbottom penetration depths. Generally, shallow-water depths at sites in Ohio limited the use of continuous seismic reflection and color fathometer. Consequently, ground-penetrating radar and the black and white fathometer were the primary methods used to investigate scour at all sites discussed in this report. These methods were used again at some sites in 1994 during low flow.

Ground-penetrating radar (GPR) systems transmit and receive high-frequency electromagnetic pulses that penetrate the subsurface and reflect from electrical inhomogeneities, such as the boundary between sand and clay. GPR antennae with a frequency of 100 or $300 \mathrm{MHz}$ were used in this study, depending upon conditions at the site. Generally, higher frequencies improve resolution of the data but reduce penetration into the subsurface. Because GPR is an electromagnetic method, it is affected by electrical interference from such sources as overhead powerlines, the electrical (specific) conductance of the water body, and conductive clays. The combination of depth, specific conductance of water, and bottom-material composition at a site sometimes precluded use of or severely limited the interpretation of GPR.

A black and white fathometer was used in conjunction with GPR to profile the stream bottom and depth of water. The fathometer was used with a 192-kHz narrow-beam transducer (8 degree), which produces a sound wave that reflects primarily from the stream bottom and does not penetrate the subsurface. The black and white fathometer profiles were used to interpret depth to reflectors in the GPR records.

Specific conductance and water-surface elevations were determined before and after GPR profiling. In the GPR method, transmitting and receiving antennae were floated on the water surface and continuous profiles were obtained along the upstream side of the bridge. The antennae were moved at a slow and uniform rate across the section, either by wading with the antennae or guiding the antennae with ropes. If the cross-sectional data showed subbottom penetration, additional profiles were sometimes obtained parallel to the sides of the bridge piers. All GPR data were recorded graphically and on digital tape for later processing.

\section{Computation of Pier-Scour Depth}

Scour researchers have used a variety of methods to establish a reference surface (plane) from which to measure the depth of scour at piers. Landers and Mueller (1993) reviewed and evaluated methods used in previous scour investigations for establishing reference surfaces for determination of bridgescour depths. They stated, "Reference surfaces should be selected so that the local, contraction, and general (long- and short-term changes unrelated to the effects of the bridge) components of total scour may be quantified separately." They recommended the use of the concurrent ambient bed elevation, based on scour-measurement channel geometry, to determine local pier-scour depth. The scour depth at a pier determined with this method isolates the local scour component of the total scour (at a pier) and does not reflect potential scour components associated with contraction or general channel scour.

In this investigation, pier-scour depth was computed as the maximum vertical distance between a concurrent ambient bed elevation (an estimate of the natural streambed elevation without the pier in place) and the lowest streambed elevation measured within the scour hole during the scour measurement (fig. 3). The concurrent ambient bed elevation was determined by use of streambed elevations adjacent 


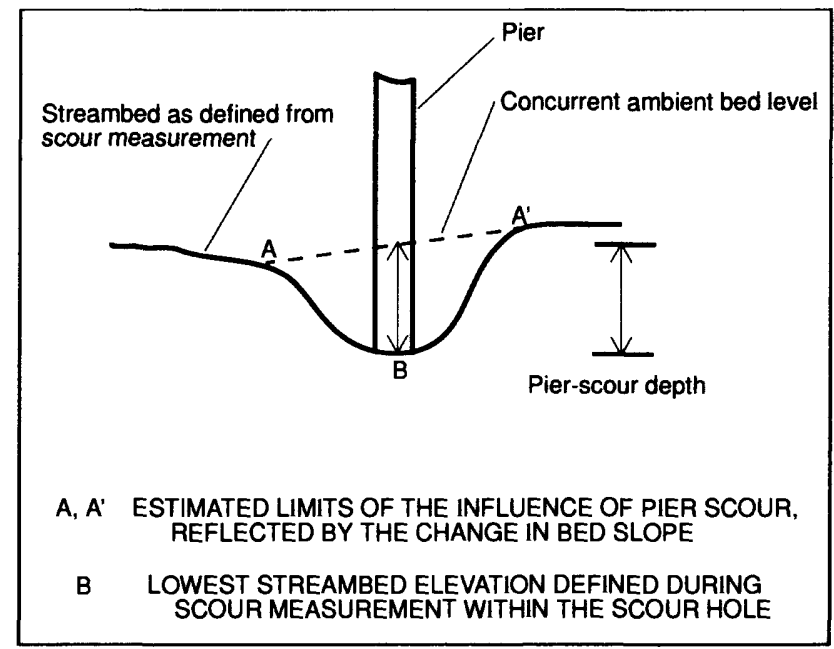

Figure 3. Determination of the concurrent ambient bed level and the resulting pier-scour depth.

to the pier, defined during the scour measurement, but outside the zone of local pier-induced flow acceleration. Computed pier-scour depths of less than $0.5 \mathrm{ft}$ were eliminated from the pier-scour data set used for subsequent statistical and graphical analysis.

The use of the concurrent ambient bed elevation based on scour-measurement channel geometry represents a maximum pier-scour depth for the flow conditions during the measurement. Most of the previous pier-scour research experiments (in laboratory flumes) were not stopped until equilibrium was reached. As mentioned previously, the measurements of scour obtained in this field-based investigation were subject to dynamic flow and sediment transport; a quantitative assessment of the equilibrium conditions was not done.

\section{Computation of Contraction-Scour Depth}

The depth of contraction scour is defined as the difference between the average streambed elevation at the bridge and the average streambed elevation at the approach (Landers and Mueller, 1993). Assessing the depth of contraction scour within a bridge opening is complicated by the potential interaction of local, contraction, and general channel scour. To properly estimate contraction-scour depth, one must isolate the contraction component of [the] total scour. Landers and Mueller (1993) state, "A reference surface that characterizes the mean bed elevation of an uncontracted (approach) section at the location of the contraction scour measurement isolates the contraction scour component of total scour." To estimate contraction scour, one ideally must make concurrent measurements of both the bridge and approach streambed sections during high flow. Nonetheless, concurrent measurements of both sections during floods are generally difficult to obtain. The bridge section can usually be measured from the bridge deck during high flows. Because of safety concerns about having personnel in a boat during flooding, however, approach-section data are rarely obtained during high flow.

No high-flow streambed elevation data were collected at approach sections during this investigation; rather, approach-section data were collected during low flow. Consequently, contraction scour was estimated from data collected during high flow at the bridge and data collected during low flow (after the flood) at the approach. The depth of contraction scour was computed as the difference in mean streambed elevations between (1) segments of the bridge section where active 
bedload transport probably occurred but was unaffected by local pier or abutment scour and (2) the segment of the approach section where active bedload transport probably occurred. Thus, the computed mean streambed elevation of the postflood approach-section data was used as the contraction-scour reference surface in this investigation.

Contraction-scour data were screened to meet the following two criteria:

1. Contraction-scour depth greater than $0.5 \mathrm{ft}$.

2. At the bridge section, a difference of greater than $0.5 \mathrm{ft}$ between the mean streambed elevation determined from low-flow data (collected before the measurement) and the mean streambed elevation determined from high-flow data.

Thus, all contraction-scour depths used for statistical and graphical analysis and presented in this report met both of the established criteria.

Two computer programs were used to compute the mean streambed elevations of the bridge and approach sections. Initially, hydraulic and cross-sectional data were compiled from the 47 scour measurements for use in the WSPRO step-backwater model (Shearman, 1990; Shearman and others, 1986). WSPRO output files were then used as input data to the Bridge $\underline{\text { Scour }}$ Analysis using WSPRO (BSAW) program (Mueller, 1993). BSAW was developed to extract data from WSPRO output files to compute selected hydraulic parameters required for subsequent scour computations. For this investigation, BSAW was used to compute the mean streambed elevations of the segments of the bridge and approach sections used for the contraction-scour analyses.

In using postflood approach-section data to establish the contraction-scour reference surface, it is assumed that streambed conditions at the approach defined by postflood data were representative of the conditions during the flood and that the approach data reflect the maximum general channel scour that occurred during the flood. If these assumptions were appreciably violated, then contraction scour based on a reference-surface elevation derived from postflood approach data would be in error. Therefore, in conjunction with the contraction-scour analysis, supplemental analyses were done to assess approachchannel stability.

As previously stated, the approach section at each scour-measurement site was surveyed annually as part of baseline data collection during low flow. Using the computer programs WSPRO and BSAW, an approach mean-streambed elevation was computed for every year a survey was done at the scourmeasurement sites. These annual mean streambed elevations were then used for two approach-channel stability assessments.

The first assessment was completed to establish the change in the approach section before and after the contraction-scour measurement. The difference in the mean streambed elevations of the preflood and postflood approach section was computed for each scour measurement where contraction scour was observed. This difference provided an indication of the potential error of the reference-surface elevation used to compute a contraction-scour depth.

The second channel-stability assessment was done to provide insight to the longer term vertical stability of the approach streambed during the data-collection phase of this investigation. Statistics were computed by use of all the annual approach-section mean streambed elevations for each of the scourmeasurement sites. The statistics computed were the mean, standard deviation, and median of the data set. The standard deviation of the annual mean-streambed elevations provided a measure of the longer term vertical stability of the streambed. 


\section{EVALUATION OF BRIDGE-SCOUR DATA}

This section of the report characterizes scour-measurement data collected at 21 study sites in Ohio and describes the subsequent analyses of pier and contraction scour. Observedpier-scour relations are compared to results of previous scour research and to computed estimates of pier-scour depth. In addition, the depth of contraction scour, the stability of the streambed at the approach (uncontracted) section, and the possibility of historical scour are discussed.

Typically, bridges are designed to accommodate and withstand large floods. FHWA currently recommends that Federal highway bridges be designed to withstand the effects of scour from a "superflood," - a flood with a recurrence interval of approximately 500 years — with little risk of failing (Richardson and others, 1993). A flood with a 500-year recurrence interval is defined as the flood that has an average annual exceedance probability of 0.002 .

To help in the interpretation of the scour data collected during this study, the approximate recurrence intervals of the streamflows measured at the time of scour measurements were determined. The estimation of recurrence intervals was limited to 16 bridge sites where flows are not significantly regulated. Long-term station records were used to obtain flood-peak discharge estimates for the 2-, 5-, 10-, 50-, and 100-year recurrence intervals for seven unregulated sites at or near USGS streamflowgaging stations. The most recent report for estimating flood-peak discharges in Ohio (Koltun and Roberts, 1990) was used to obtain the flood-peak discharge estimates for the other nine unregulated study sites not near USGS streamflow-gaging stations. The 35 instantaneous streamflows used for this analysis were discretized by recurrence-interval ranges. A histogram of recurrence-interval ranges is shown in figure 4 . Of the 35 streamflows measured at unregulated sites, 27 ( 77 percent) were less than the estimated 2-year flood. Only 1 of the 35 measured streamflows was greater than the estimated 50-year flood. None of the 35 measured streamflows was greater than the estimated 100-year flood. Although 77 percent of the measured streamflows were smaller than the 2-year flood, pier scour was found in all but 2 of the 47 measurements.

\section{Local Scour at Bridge Piers}

Local scour occurs around obstructions in the flow, such as bridge piers, abutments, spurs, and highway embankments. Pier scour, a specific case of local scour, is the erosion of streambed materials in the vicinity of bridge piers caused by acceleration and local disturbances (vortices and eddies) of the flow. Pier-scour depth greater than or equal to $0.5 \mathrm{ft}$ was observed at one or more piers per site in 45 of the 47 measurements ( 84 cases of pier scour were documented). The pier-scour data base includes multiple observations of scour at some piers (from scour measurements obtained on different dates) and, at some bridge sites, scour at multiple piers. Selected pier, approach-flow, and bedmaterial data for the 84 cases of pier scour are listed in table 2 presented in the appendix.

Each pier-scour measurement was assigned an estimated error on the basis of a visual evaluation of measurement conditions at the site and interpretation of the measurement data. Measurement conditions considered when assigning the estimated error included location of the channel thalweg, presence of debris, flow turbulence, and sounding-weight drift. Also considered in assigning the estimated error was the potential inaccuracy in establishing the reference surface for the computation of pier-scour depth. The estimated error for the 84 cases of measured pier-scour depths ranged from $0.5 \mathrm{ft}$ to $1.0 \mathrm{ft}$. Any measured pier-scour depth less than the estimated error was omitted from subsequent analyses. 


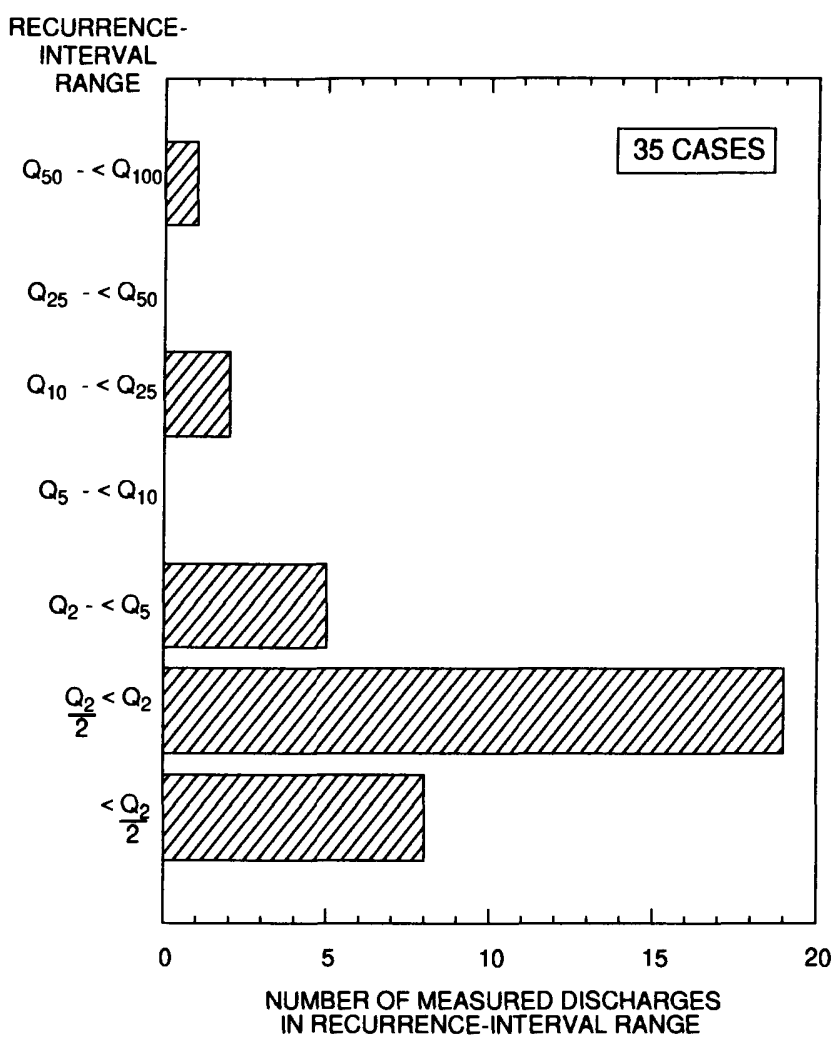

Figure 4. Summary of the scour measurement discharges ranked by recurrence-interval ranges for selected unregulated bridge-scour study sites in Ohio.

\section{Analysis of all Cases of Observed Pier-Scour Data}

Research has shown that pier scour is influenced by the interaction of several factors that may be classified into three major groups: pier attributes, flow attributes, and bed-material characteristics. The relations between selected factors and pier scour are investigated in this section of this report. Scourrelated factors associated with pier attributes include the width of the bridge pier $(b)$, effective pier width (the width of the bridge pier projected normal to the approach flow) $\left(b_{e}\right)$, pier-nose shape, and the angle of the approach flow relative to the long axis of the pier $(\alpha)$. Factors associated with flow attributes include depth of flow immediately upstream from the bridge pier $\left(y_{o}\right)$; velocity of the approach flow immediately upstream from the bridge pier $\left(V_{o}\right)$; Froude number of the flow $(\boldsymbol{F})$; and the critical velocity $\left(V_{c}\right)$, the velocity required for incipient bed-material motion. Factors associated with bed-material characteristics include median grain size of the bed material $\left(d_{50}\right)$; the grain size for which 95 percent are finer $\left(d_{95}\right)$; and the geometric standard deviation of particle-size distribution $(\sigma)$, a measure of the sediment gradation of the bed material. Some of the factors of interest were normalized to reduce or eliminate scale effects, thereby permitting comparisons of various data sets.

Observed pier-scour depth $\left(y_{s}\right)$ and (or) pier-scour depth normalized by effective pier width $\left(y_{s} / b_{e}\right)$ were correlated with selected scour factors. The scour research indicates that pier-scour depth (and normalized pier-scour depth) is monotonic for several of the factors. Therefore, Spearmans rank correlation coefficient, a measure of the strength of an increasing (or decreasing) relation between two factors, was used for the correlation analysis. Results of the correlation analysis are given in table 3. 
Two-tailed $p$ values are also reported for each of the selected relations in table 3. The strongest correlation was found between pier-scour depth normalized by effective pier width $\left(y_{s} / b_{e}\right)$ and flow depth normalized by effective pier width $\left(y_{o} / b_{e}\right)$; the Spearmans rank correlation coefficient was 0.79 . The next strongest correlation, 0.72 , was found between $\left(y_{s} / b_{e}\right)$ and Froude number $(\boldsymbol{F})$.

\section{Sediment-transport conditions}

Pier scour occurs during one of two sediment-transport conditions: clear-water or live-bed scour. During clear-water scour, a negligible amount of bed material is being transported into the zone of local scour. During live-bed scour, an appreciable amount of bed material is being transported into the zone of local scour from an upstream source. Live-bed scour occurs when the shear force exerted on the streambed particles (upstream of the bridge) is sufficient to dislodge and carry the bed material downstream.

Scour measurements were classified as either live-bed or clear-water conditions on the basis of a comparison of the approach velocity $\left(V_{o}\right)$ measured immediately upstream from the pier with an estimate of the critical velocity $\left(V_{c}\right)$ required for incipient bed-material motion (median grain size and smaller will be transported) as determined by Neill's equation (Richardson and others, 1993):

$$
V_{c}=1.58\left\{\left(S_{g}-1\right) g d_{50}\right\}^{\frac{1}{2}}\left(y / d_{50}\right)^{\frac{1}{6}},
$$

where

$$
\begin{aligned}
& V_{c} \text { is critical velocity for the median grain size }\left(d_{50}\right) \text { bed material, } \\
& d_{50} \text { is median grain size of the bed material, } \\
& g \text { is acceleration due to gravity, } \\
& S_{g} \text { is specific gravity of bed material (assumed to be 2.65), and } \\
& y \quad \text { is depth of flow. }
\end{aligned}
$$

If $V_{o}$ equaled or exceeded $V_{c}$, then the measurement was classified as live-bed scour. If $V_{o}$ was less than $V_{c}$, the measurement was classified as clear-water scour. This classification procedure resulted in 55 cases of clear-water scour and 29 cases of live-bed scour.

\section{Scour-hole characteristics}

As discussed earlier, pier-scour depth was computed as the difference between the concurrent ambient bed level and the lowest streambed elevation measured within the scour hole during the scour measurement. The 84 cases of measured pier-scour depths observed in this study ranged from 0.5 to $6.1 \mathrm{ft}$. A histogram showing the frequency of occurrences of pier-scour depths is shown in figure $5 \mathrm{~A}$.

The top width of each scour hole was determined from interpretation of the measured cross-sectional channel-geometry data obtained along the upstream side of the bridge during scour measurement. Specifically, top width was determined by measuring the distance between points on both sides of the pier where the cross-sectional profiles initially deviated from the profile implied by interpolation of the concurrent ambient bed level. A histogram showing the frequency of occurrences of top widths is shown in figure $5 \mathrm{~B}$.

The scour-hole side slope was determined as the average of the slopes of both sides of the scour hole, as defined from the channel-geometry data. Each slope was computed as the ratio of the horizontal distance (from the bottom to the outer edge of the scour hole) to the vertical distance (from the 
Table 3. Correlation data for selected scour factors for 84 cases of observed pier scour in Ohio

$v_{s}$, scour depth; $y_{s} / b_{e}$, normalized scour depth; $b$, pier width; $y_{o}$, flow depth; $y_{g} / b_{e}$, normalized flow depth; $V_{d} / V_{c}$, flow intensity; $F$, Froude number; Pier $d_{50}$, median grain size of pier bed material; Pier $d_{95}$, grain size for which 95 percent of pier bed particles are finer; Pier $\sigma^{\mathrm{a}}$ standard deviation of particle-size distribution of pier bed material]

\begin{tabular}{cccc}
\hline Factor 1 & Factor 2 & $\begin{array}{c}\text { Spearman rank } \\
\text { correlation } \\
\text { coefficient }\end{array}$ & $\begin{array}{c}\text { p value } \\
\text { (2-tail) }\end{array}$ \\
\hline$y_{s}$ & $b$ & 0.32 & 0.003 \\
$y_{s}$ & $b_{e}$ & .31 & .004 \\
$y_{s}$ & $y_{o}$ & .11 & .300 \\
$y_{s} b_{e}$ & $y_{d} b_{e}$ & .79 & .000 \\
$y_{s} b_{e}$ & $V_{o} / V_{c}$ & .58 & .000 \\
$y_{s} b_{e}$ & $F$ & .72 & .000 \\
$y_{s} b_{e}$ & Pier $d_{50}$ & .15 & .175 \\
$y_{s} b_{e}$ & Pier $d_{95}$ & .03 & .755 \\
$y_{s} b_{e}{ }^{a}$ & Pier $\sigma^{\mathrm{a}}$ & $-.30^{\mathrm{a}}$ & $.007^{\mathrm{a}}$ \\
\hline
\end{tabular}

${ }^{\mathrm{a} C}$ Correlation data for 81 cases of observed pier scour.

bottom to the top of the scour hole). The convention of horizontal to vertical was used to be consistent with data input requirements of the Bridge Scour Data Management System software developed to compile the national scour data base for the USGS National Scour Study (Landers and Mueller, 1996). The two side slopes were averaged and are reported as the scour-hole side slope. A histogram showing the frequency of occurrences of the scour-hole side slope data is shown in figure $5 \mathrm{C}$.

\section{Pier attributes}

Pier width and length. Pier widths were obtained directly from bridge-site plans for all cases of pier scour unless it was determined that pier footings were exposed during scour measurement. If the pier footings were exposed, a depth-weighted pier width of the exposed part of the pier and footing was calculated by use of a method described by Jones and others (1992). The range of pier widths in this investigation was 0.8 to $5.4 \mathrm{ft}$, and the median was $3.0 \mathrm{ft}$. A histogram showing the frequency of occurrences of pier widths is shown in figure 6.

Relations between selected factors were interpreted visually on the basis of scatterplots. Generally, considerable variability of the data is indicated, as would be expected from field measurements. LOWESS (locally weighted scatterplot smooth) curves were superimposed on selected scatterplots to help visualize relations indicated by the scatter of the data (Cleveland, 1979; Cleveland and McGill, 1984).

LOWESS curves are useful for analysis because they show relations between two variables without assuming linearity. LOWESS is an iterative technique that involves the use of robust-weighted least-squares regression to compute the points of a smooth curve through the scatterplot data. A smoothing factor of 0.7 was used for all LOWESS curves for this study. 

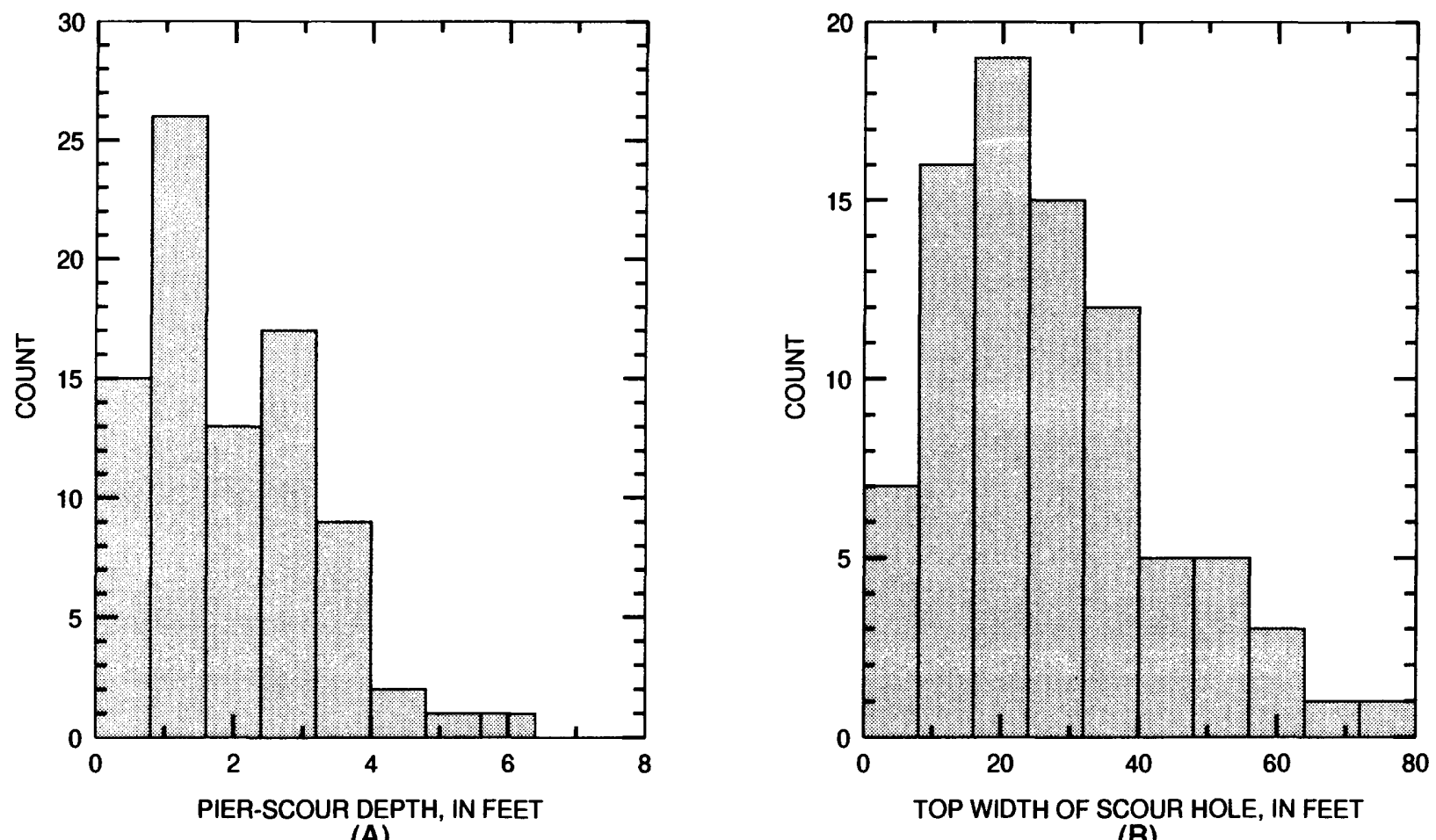

(A)

(B)

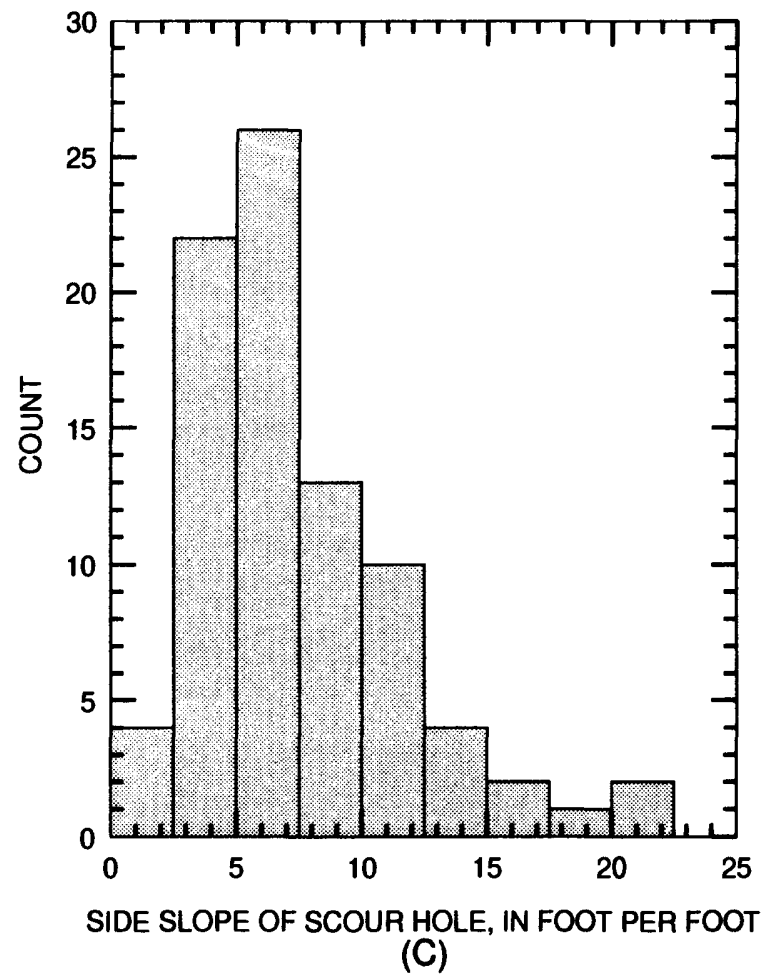

Figure 5. Characteristics of measured pier-scour holes at bridge-scour study sites in Ohio: (A) pier-scour depth, (B) top width, and (C) side slope. 


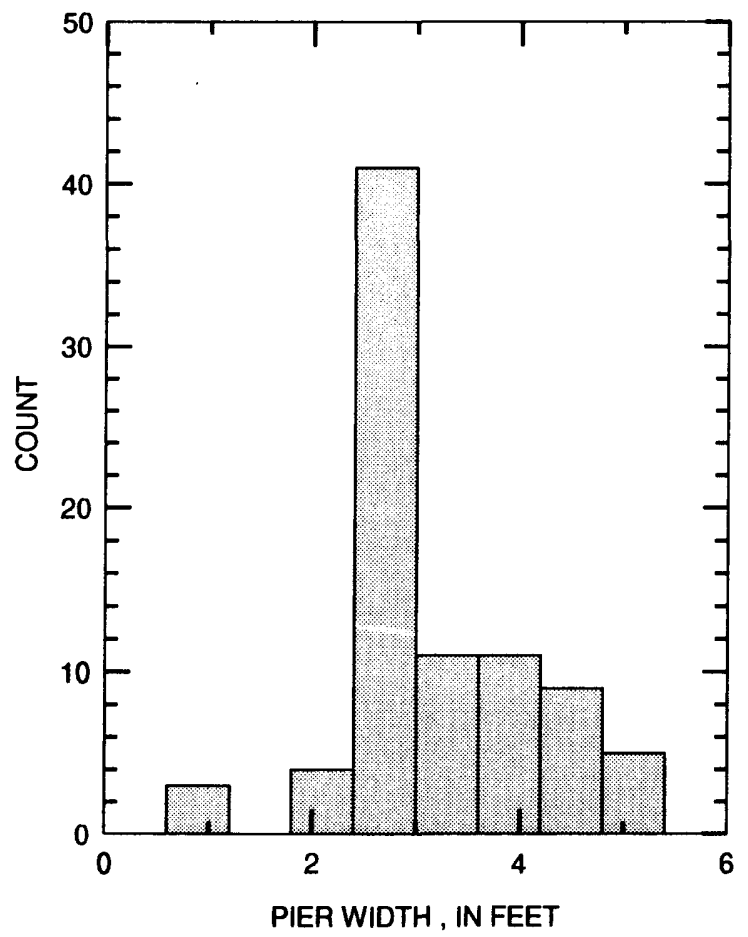

Figure 6. Histogram of pier widths at bridgescour study sites in Ohio.

The relation of pier-scour depth $\left(y_{s}\right)$ to pier width $(b)$ for the 84 cases of observed pier scour is shown in figure 7 . The slope of the LOWESS curve indicates a generally increasing relation between pier-scour depth and pier width. The maximum observed ratio of scour depth to pier width $\left(y_{s} / b\right)$ is 1.7 for clear-water scour and 1.4 for live-bed scour. Ratios of pier-scour depth to pier width were greater than 1 in 11 of the 84 cases. Melville and Sutherland (1988) stated that a limiting value of pier-scour depth can be taken as 2.4 times the pier width $(b)$. All pier-scour depths observed in this study lie below the line representing that function (fig. 7).

Pier length - the distance measured along the longest longitudinal axis of the pier-was obtained from bridge-site plans. It has been suggested that pier length has no significant effect upon pier-scour depth if the pier is aligned with the flow (Richardson and others, 1993). Pier lengths in this study ranged from 24.3 to $81.8 \mathrm{ft}$ for the 84 cases of pier scour. A histogram showing the frequency of pier lengths is shown in figure 8 .

Pier alignment. The width of flow effectively obstructed for a noncylindrical pier (referred to as the effective pier width) is computed as

$$
b_{e}=L \sin (\alpha)+b \cos (\alpha),
$$

where

$b_{e}$ is width of the bridge pier projected normal to the approach flow,

$L$ is pier length,

$b$ is pier width, and

$\alpha$ is angle of approach flow referenced to the bridge pier (attack angle). 
The factors used in the computation of the effective pier width are shown in figure 9. As equation 2 indicates, the value of effective pier width $\left(b_{e}\right)$ is equal to pier width $(b)$ when the angle of the approach flow is zero. A histogram showing the frequency of occurrence of piers with varied alignments (fig. 10B) indicates that an attack angle exceeded 10 degrees in 39 of the 84 cases of pier scour. A histogram of the frequency of occurrence of effective pier widths is shown in figure 10A. A number of effective pier widths exceed $50 \mathrm{ft}$, which reflect data collected during three scour measurements at State Route 41 over the Great Miami River at Troy (site 5). (This location was purposely selected to include at least one measurement site where flows would be substantially angled to the piers.) There are 8 piers at this site, and 7 cases of pier scour were observed during each measurement (resulting in a total of 21 cases of pier scour at site 5); the angle of approach flow was about 60 degrees for all 21 cases.

A scatterplot and LOWESS smooth of the relation of pier-scour depth to effective pier width $\left(b_{e}\right)$ is shown in figure 11. The LOWESS curve indicates a generally increasing relation between pier-scour depth and effective pier width. The shape of the curve is strongly influenced by a cluster of data (which includes the 21 cases of pier scour at site 5) near the upper range of effective pier width. The previously discussed correlation analysis table 3 , indicated a weak (Spearmans rank correlation coefficient of 0.31 ) increasing relation between pier-scour depth $\left(y_{s}\right)$ and effective pier width $\left(b_{e}\right)$. The trend of the LOWESS curve and the correlation analysis for the measured data weakly support the hypothesis that scour increases as effective pier width increases.

Pier-nose shape. Measurement sites were selected so as to represent a variety of pier shapes. It was evident from reconnaissance visits to potential measurement sites that piers with round faces were the most prevalent. The distribution of pier shapes for the 84 pier-scour measurements, is 54 round (64 percent), 29 sharp ( 35 percent), and 1 square ( 1 percent).

\section{Flow Attributes}

Flow depth. Flow depths measured in this study ranged from 3.0 to $19.8 \mathrm{ft}$ (fig. 12). A scatterplot of the relation of pier-scour depth $\left(y_{s}\right)$ to flow depth $\left(y_{o}\right)$ is shown in figure 13. The LOWESS curve indicates that pier scour depth monotonically increases with flow depth to about $8 \mathrm{ft}$. At flow depths greater than $8 \mathrm{ft}$, pier-scour depth appears to decrease and then increase again, but the slope of the curve is less steep than the slope for flow depths less than $8 \mathrm{ft}$.

The relation between pier-scour depth normalized by effective pier width $\left(y_{s} / b_{e}\right)$ and flow depth normalized by effective pier width $\left(y_{o} / b_{e}\right)$ is shown in figure 14. The LOWESS curve through these data indicates that $y_{s} / b_{e}$ increases with $y_{o} / b_{e}$ to a $y_{o} / b_{e}$ value of approximately 2.5 . An increasing relation is also indicated for $y_{o} / b_{e}$ values exceeding 2.5, but the slope of the relation is flatter (the rate of increase is slower) than for $y_{d} / b_{e}$ values less than 2.5. The observed trend, as indicated by the LOWESS curve, provides some support to Melville and Sutherland's conclusion (1988) that scour depth increases up to a limiting value of 3 for the ratio of flow depth to pier width and that the effect reflected by this ratio is insignificant beyond the limiting value.

Flow velocity. The relation between pier-scour depth and four flow-related factors-approach velocity $\left(V_{o}\right)$; critical velocity $\left(V_{c}\right)$; the ratio of approach velocity to critical velocity, an indication of "flow intensity" $\left(V_{o} / V_{c}\right)$; and Froude number $(F)$-were investigated. Histograms showing the frequency of occurrence of these factors are shown in figure 15.

A scatterplot of the relation of pier-scour depth normalized by effective pier width $\left(y_{s} / b_{e}\right)$ and flow intensity $\left(V_{o} / V_{c}\right)$ is shown in figure 16. Of interest in this figure are the maximum values of normalized scour depth; therefore, a LOWESS curve is not plotted. For the clear-water scour measurements, the data indicate a sharp increase in normalized scour depth (maximum $y_{s} / b_{e}$ values near 1 ) as $V_{o} / V_{c}$ approaches the threshold of 1 . Normalized scour depths decrease at the transition from clearwater to live-bed scour $\left(V_{o} / V_{c}=1\right)$. The observed trend of the maximum values of normalized scour depth (as $V_{o} / V_{c}$ approaches and exceeds 1) is consistent with the first scour maximum described by Melville (1988) and as illustrated previously in figure 1. However, the data do not exhibit the second 


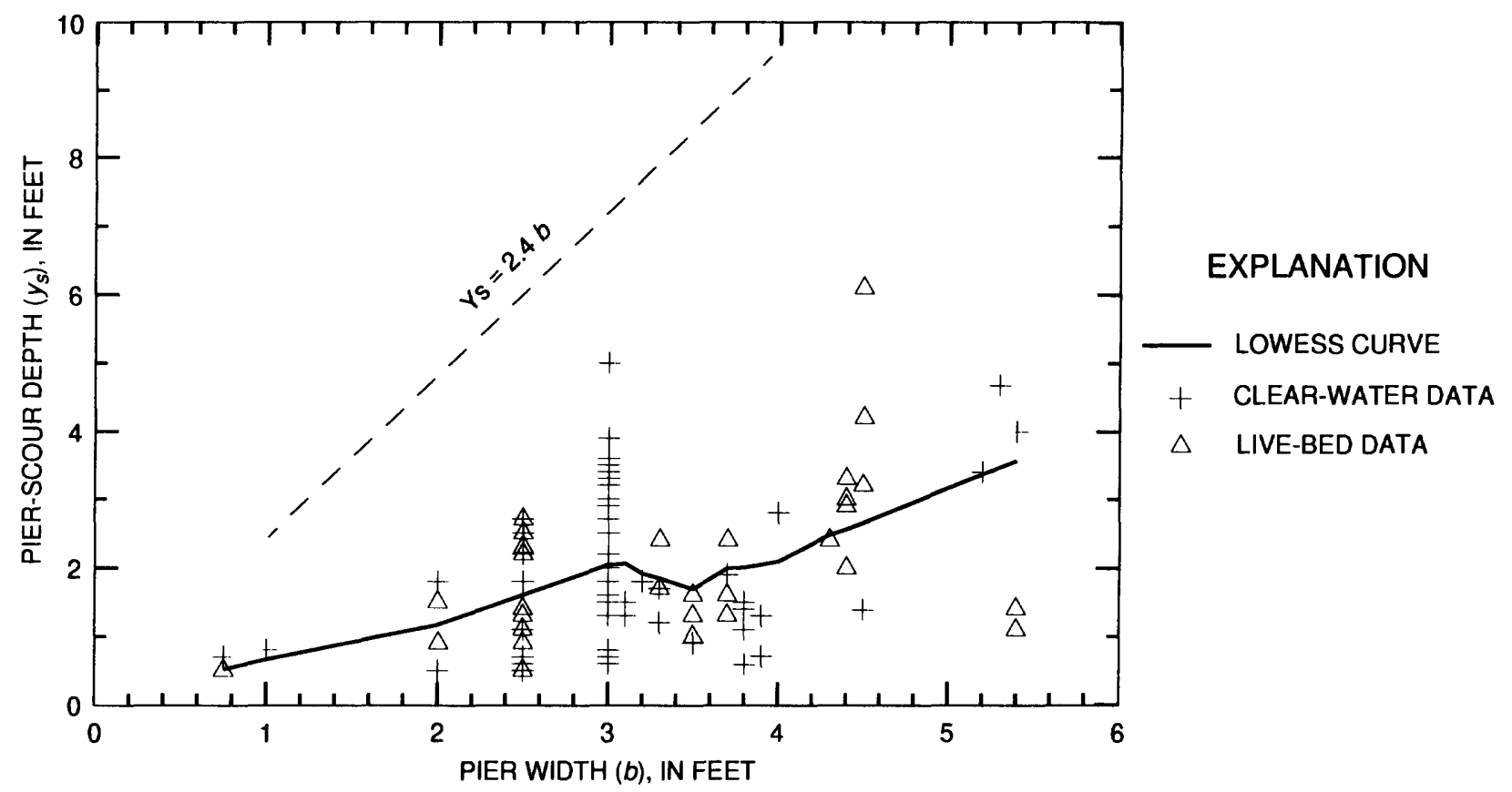

Figure 7. Relation of pier-scour depth to pier width at bridge-scour study sites in Ohio.

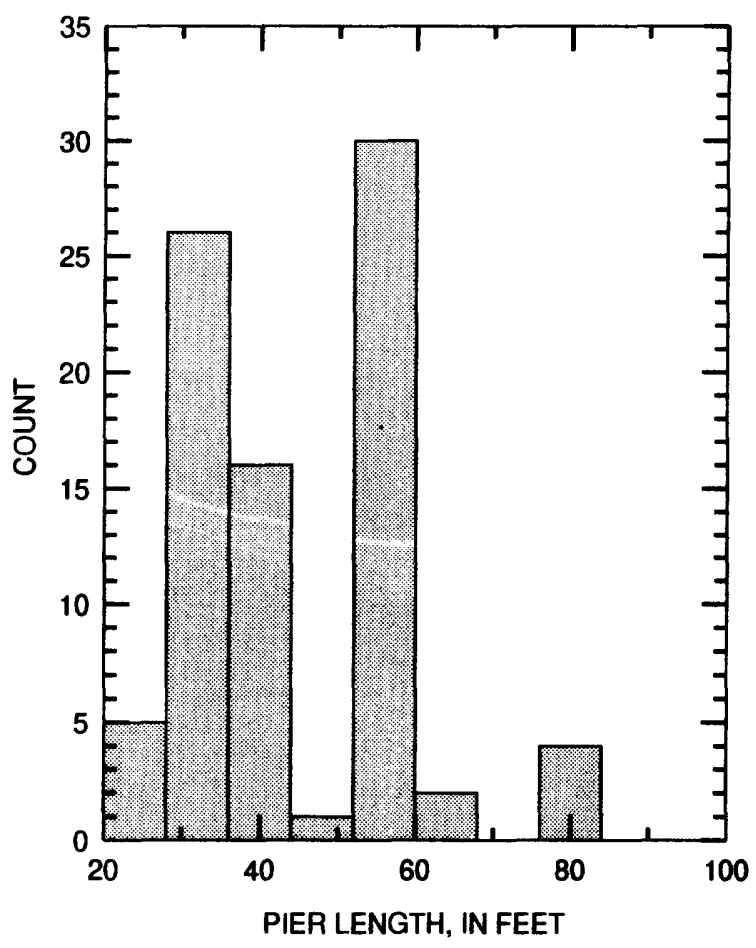

Figure 8. Histogram of pier lengths at bridgescour study sites in Ohio. 


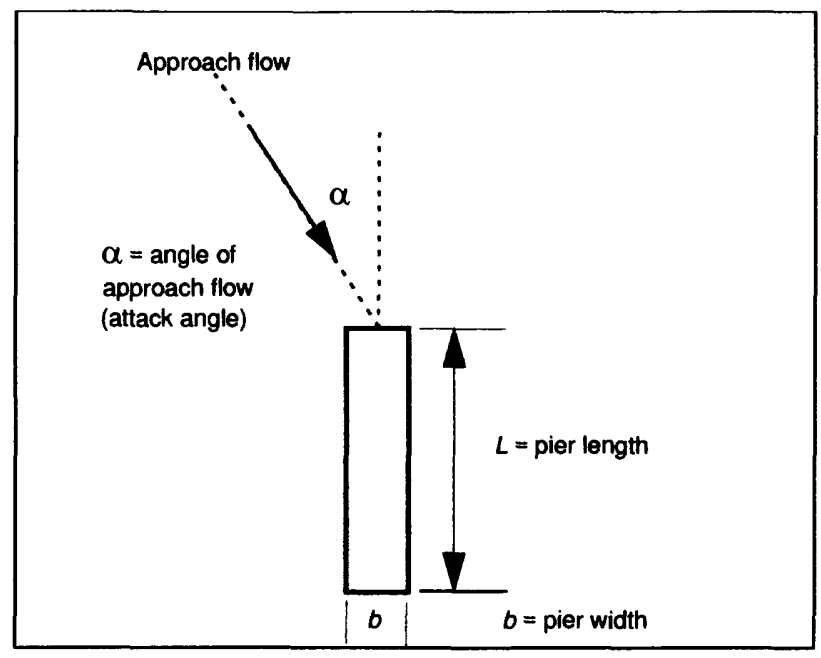

Figure 9. Sketch illustrating determination of the effecitve pier width.

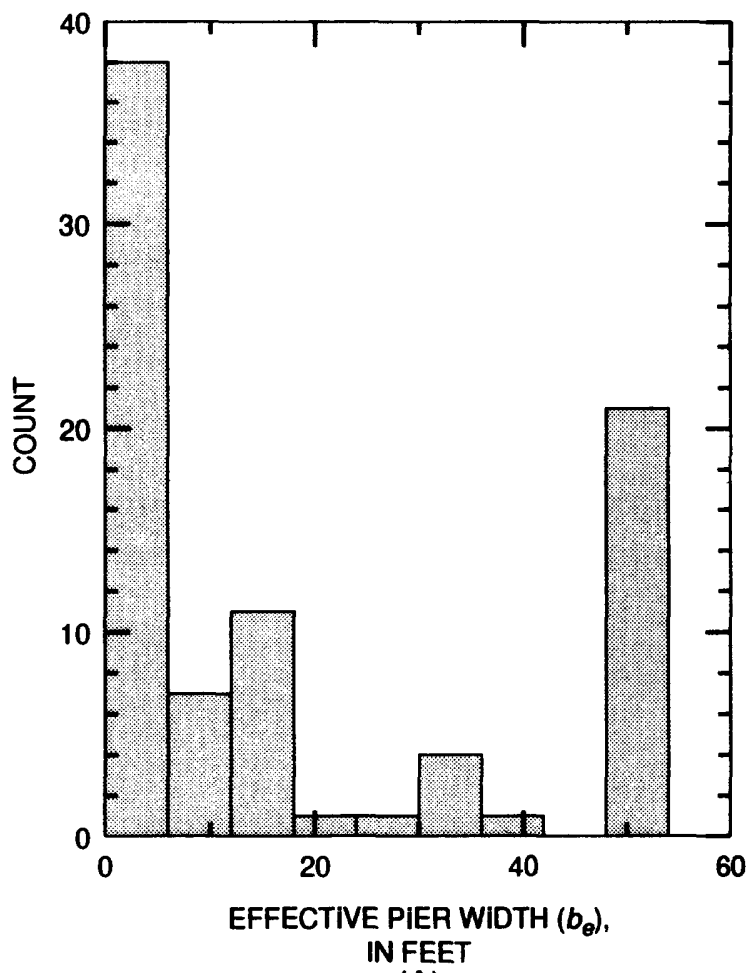

(A)

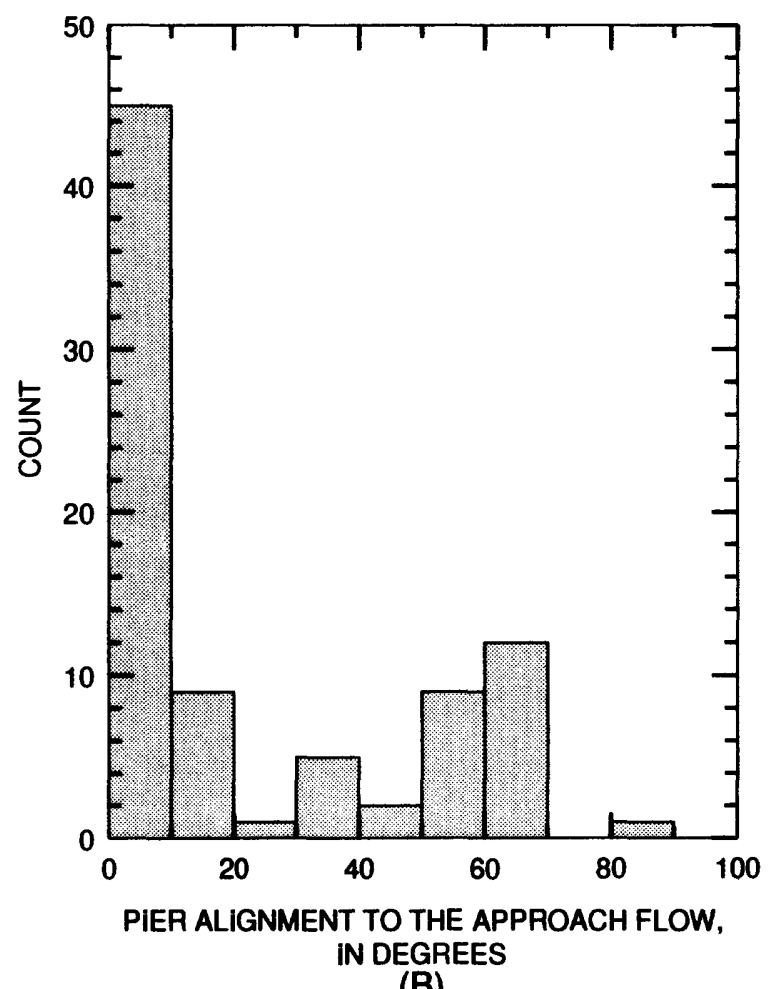

(B)

Figure 10. Characteristics of pier alignment at bridge-scour study sites in Ohio: (A) effective pier width and (B) pier alignment to the approach flow. 


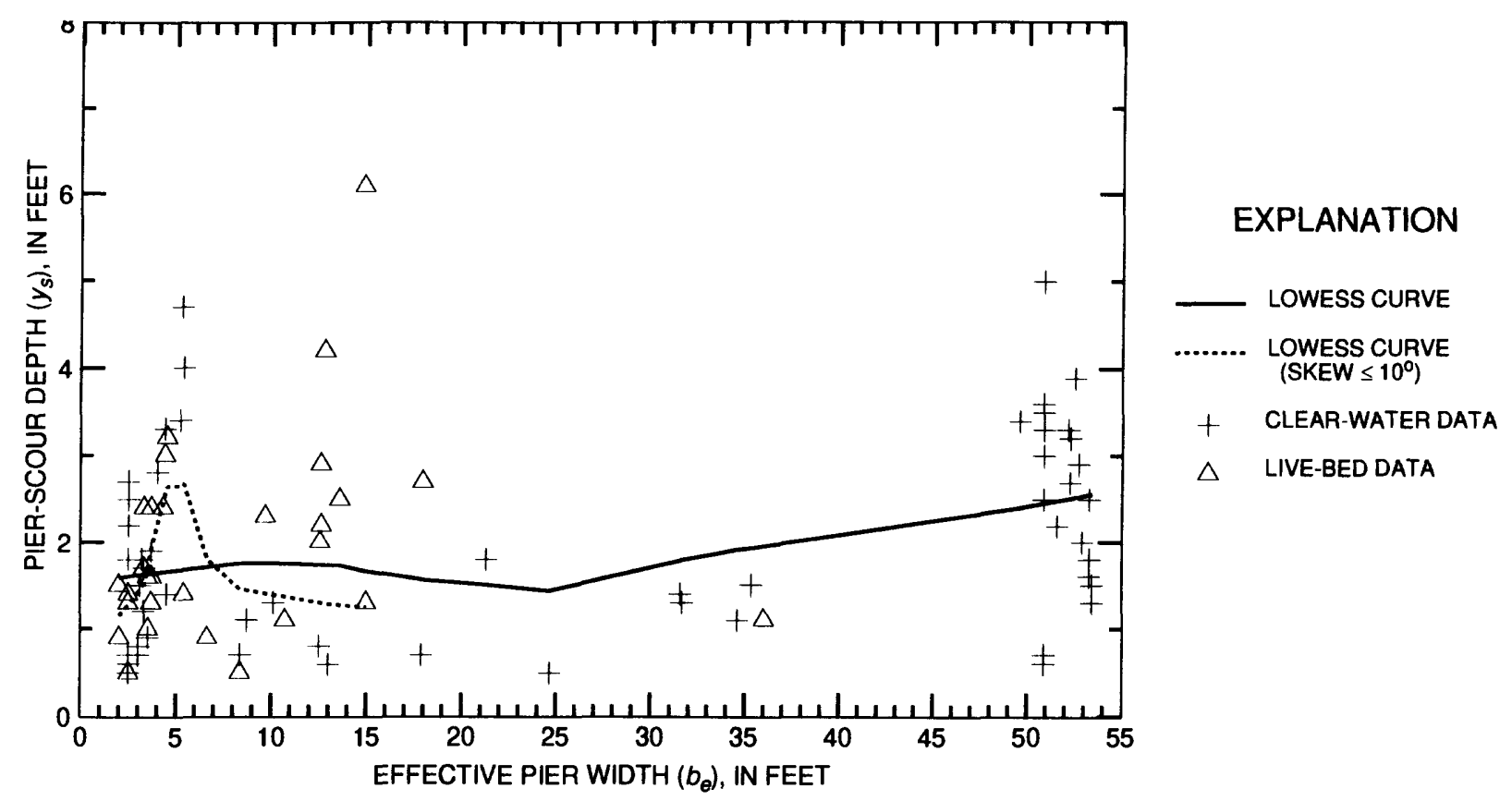

Figure 11. Relation of pier-scour depth to effective pier width at bridge-scour study sites in Ohio.

scour maximum described by Melville, but few data were collected at $V_{o} / V_{c}$ greater than 2, where the second maximum would be expected.

A scatterplot of the relation between pier-scour depth normalized by effective pier width $\left(y_{s} / b_{e}\right)$ to Froude number $(\boldsymbol{F})$ is shown in figure 17. These data indicate that all pier-scour measurements for this study were obtained at flow conditions well within the subcritical range $(F<1)$; none of the Froude numbers exceed 0.5 . The LOWESS curve indicates that pier-scour depth normalized by effective pier width increases with Froude number and increases more rapidly where $\boldsymbol{F}$ exceeds $\mathbf{0 . 2}$.

Two pier-scour prediction equations, the Federal Highway Administration's (FHWA) HEC 18 equation, (Richardson and others, 1993) and the Froehlich equation (1988) include a Froude number term to the 0.43 power and 0.20 power, respectively (fig. 17). The term in the Froehlich equation envelops all but five of the data points from this investigation. The term in the FHWA HEC 18 equation envelopes most of the data points, but not as many as the Froehlich equation term does. Both terms provide approximate upper envelopes for the range of data measured in Ohio.

\section{Bed-material characteristics}

Sediment size. Throughout the period of data collection, attempts were made annually during low flow to collect bed-material samples at active scour-measurement sites. Bed-material samples referred to in this report as "pier-area samples" were collected immediately upstream from each pier in or near the main channel. Bed-material samples referred to as "bridge-area samples" consisted of a composite of the bed materials collected at several locations along the upstream side of the bridge. Histograms showing the frequency of occurrence of selected sediment sizes for the samples collected at the pier and bridge locations are depicted in figure 18. During the final 2 years of data collection, composite samples were also collected along the approach section at each site; these are referred to as "approach-area samples."

Boxplots of the distributional characteristics of median grain size $\left(d_{50}\right)$ for all samples collected during the study are shown in figure 19. The range of data for the median grain size of the bed-material 


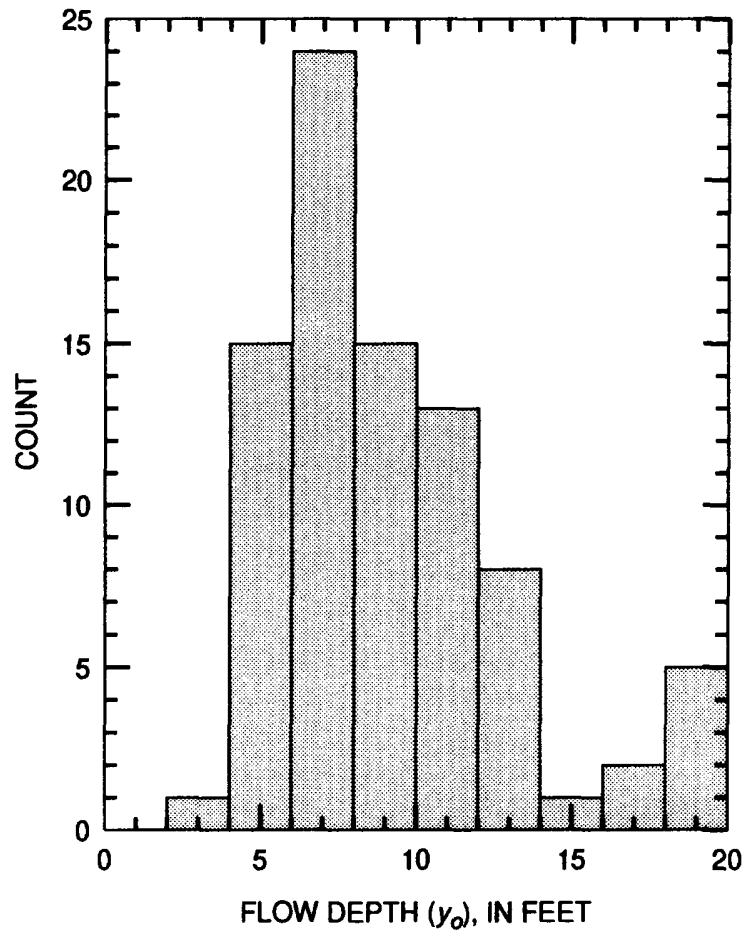

Figure 12. Histogram of flow depth at bridgescour study sites in Ohio.

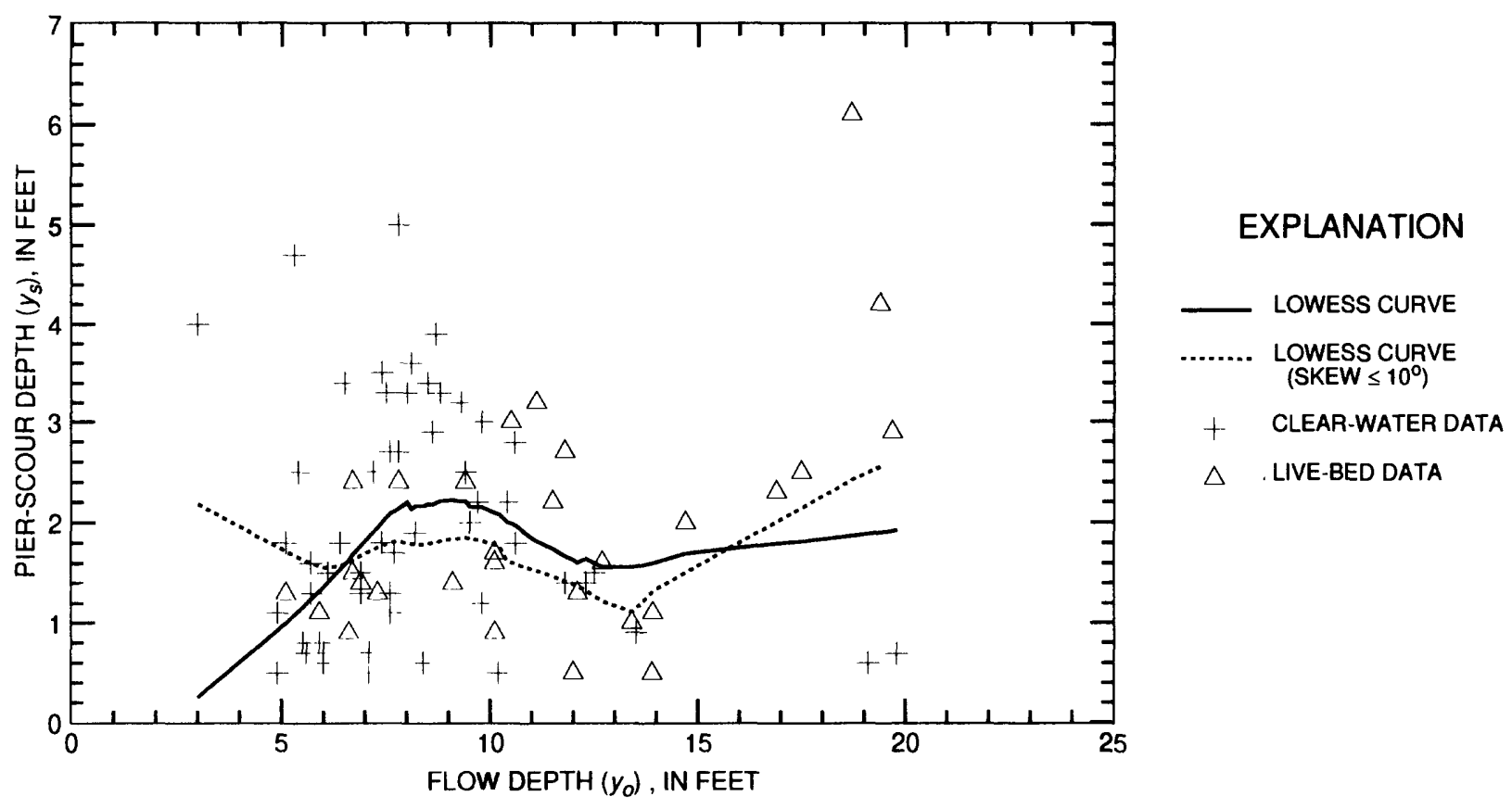

Figure 13. Relation of pier-scour depth to flow depth at bridge-scour study sites in Ohio. 


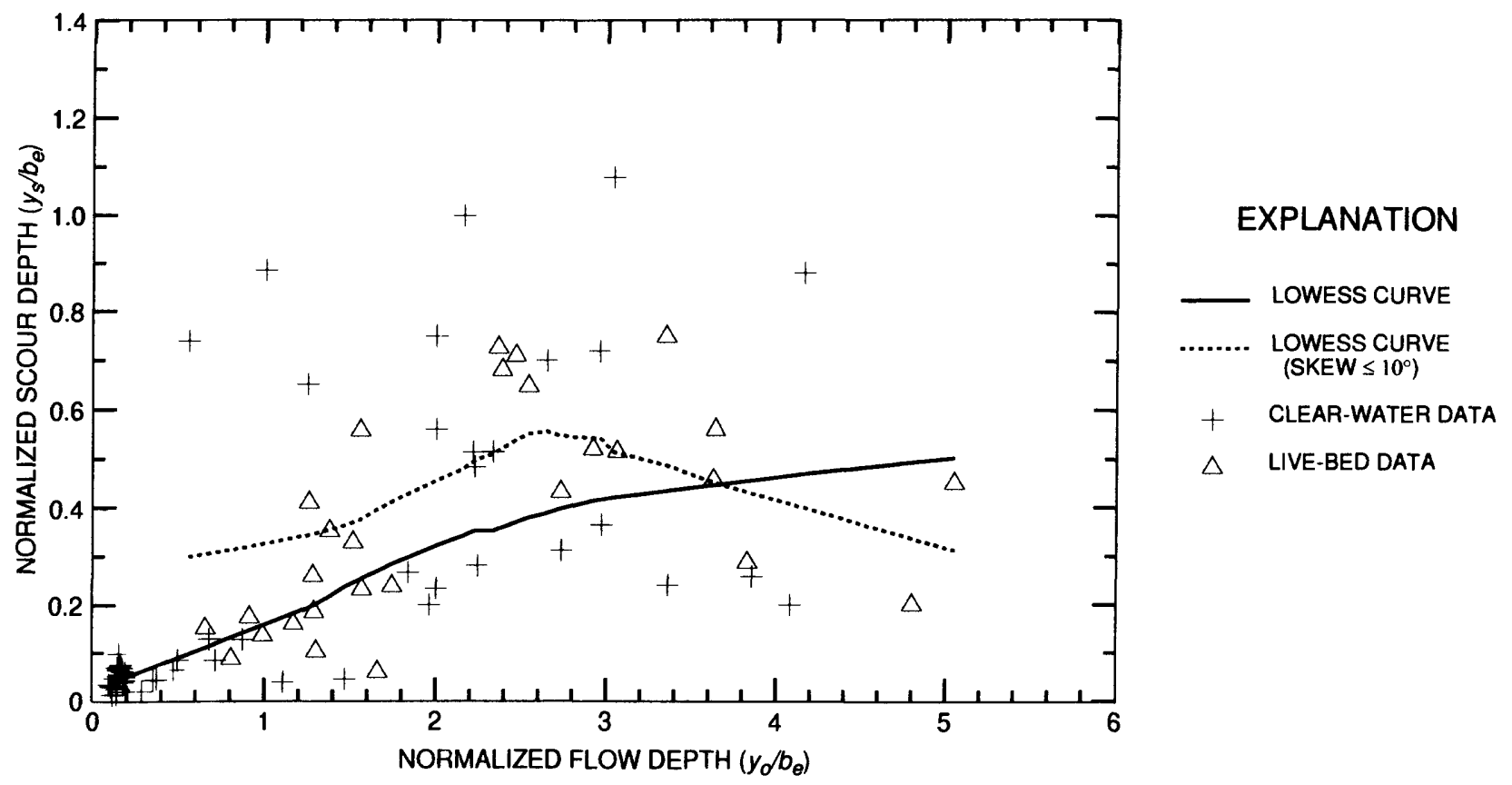

Figure 14. Relation of normalized pier-scour depth to normalized flow depth at bridge-scour study sites in Ohio.

samples is 0.008 to $60 \mathrm{~mm}$ for pier-area samples, 0.088 to $46 \mathrm{~mm}$ for bridge-area samples, and 0.092 to $48 \mathrm{~mm}$ for approach-area samples. The interquartile range (the distance between the 75th and 25 th percentiles, represented by the box height) of the boxplot for the approach-area samples indicates the largest variance among all three sets of the bed-material samples. The approach-area samples also had the largest median of the $d_{50}(12 \mathrm{~mm})$, followed by the bridge-area samples $(5.3 \mathrm{~mm})$ and the pier-area samples $(2.85 \mathrm{~mm})$.

The medians of the $d_{50}$ values for the three sets of bed-material samples were tested for statistical difference $(p=0.005)$ by use of the Wilcoxon Rank Sum test. Results of the tests indicated no significant difference between the medians of the $d_{50}$ values for the bridge- and pier-area samples; however, the results indicated a significant difference between the medians of the $d_{50}$ values for the approacharea samples when compared to the bridge- and pier-area samples.A scatterplot of the relation of pierscour depth normalized by effective pier width $\left(y_{s} b_{e}\right)$ to median grain size $\left(d_{50}\right)$ of pier-area samples is shown in figure 20 for the 84 cases of pier scour in this study. The shape of the LOWESS curve indicates that normalized scour depth increases with median grain size up to about $10 \mathrm{~mm}$, then normalized scour depth decreases as median grain size increases further. The trend indicated by the LOWESS curve for $d_{50}$ less than $10 \mathrm{~mm}$ conflicts with previous research findings (that scour depth decreases as sediment size increases). Only for $d_{50}$ greater than $10 \mathrm{~mm}$ does the shape of the LOWESS curve indicate a decrease in scour depth with an increase in sediment size.

This discrepancy between the observed relation between normalized scour depth and median grain size and the results of previous laboratory research suggests that other potential influencing factors may exist. Two possible factors which may have influenced the observed trend are bed-material cohesion and scour measurements made at nonequilibrium conditions. Cohesion influences the rate of scour for fine bed materials (silts and clays). Richardson and others (1993) commented on the effect of cohesion on scour depth: "With cohesive bed materials it will take much longer to reach maximum scour depth, the result of many flood events." Field measurements for this study were collected as near 

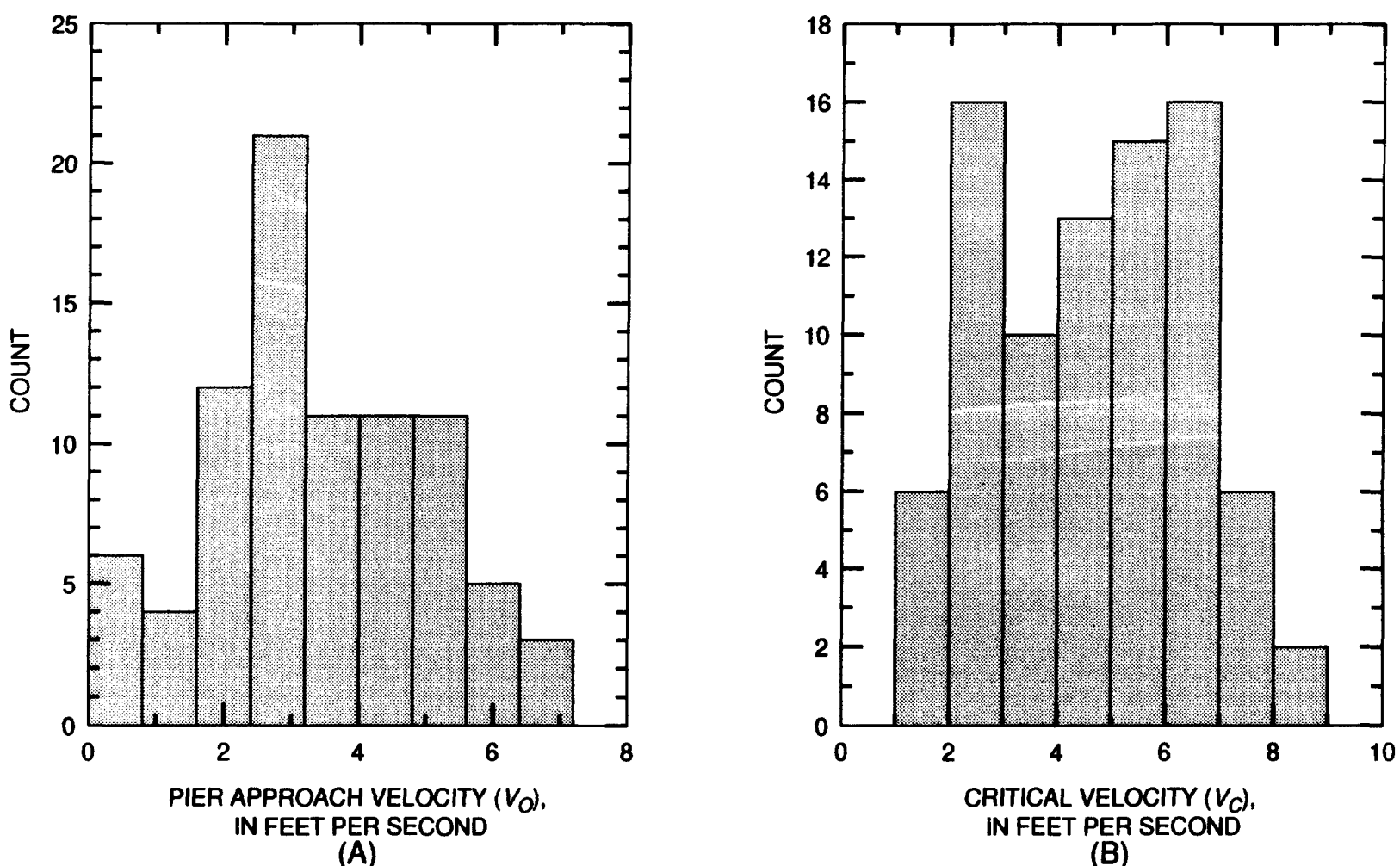

(B)
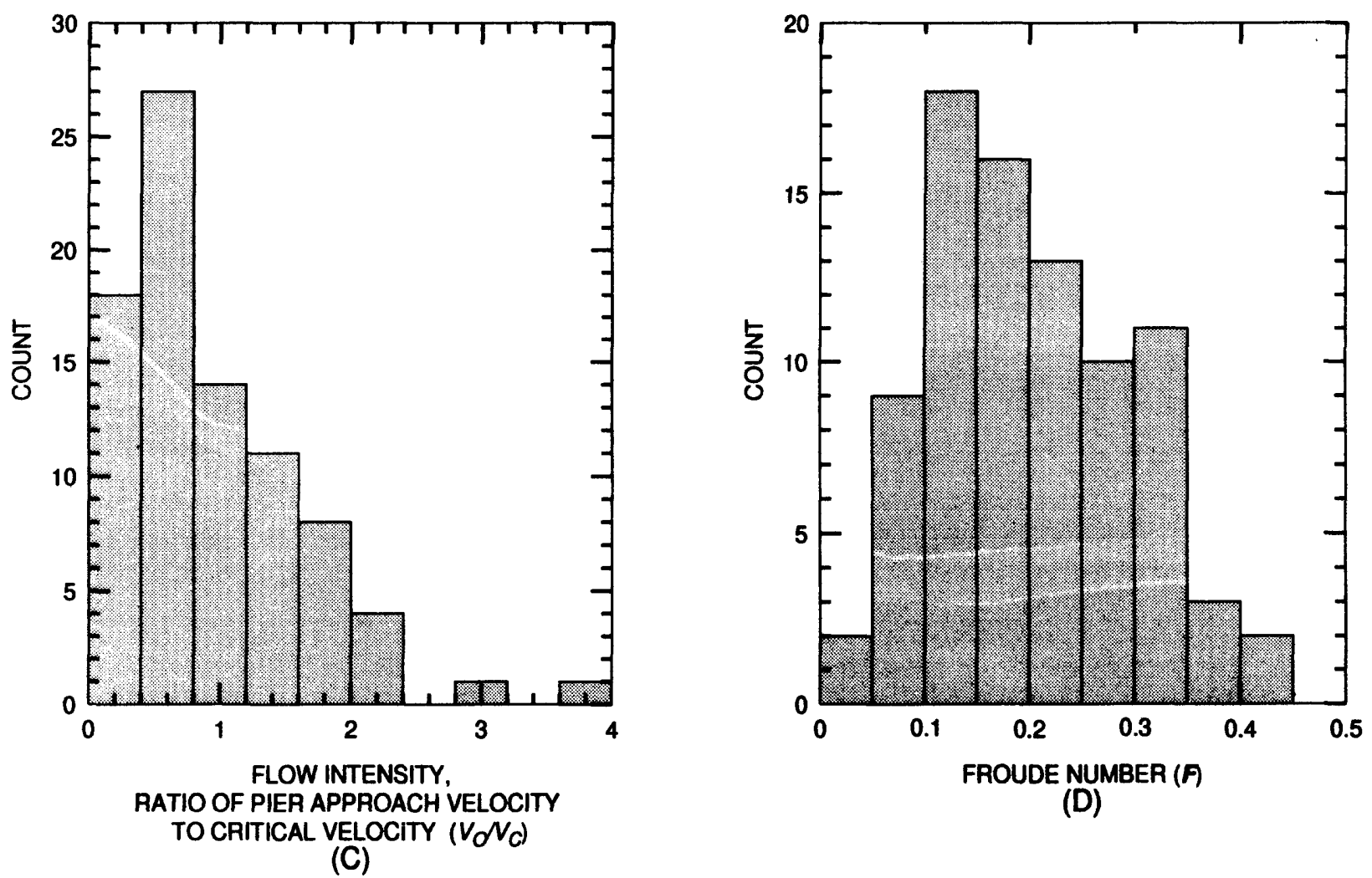

(D)

Figure 15. Characteristics of flow attributes at bridge-scour study sites in Ohio: (A) pier approach-flow velocity, (B) critical velocity, (C) flow intensity, the ratio of pier approach-flow velocity to critical velocity, and (D) Froude number. 


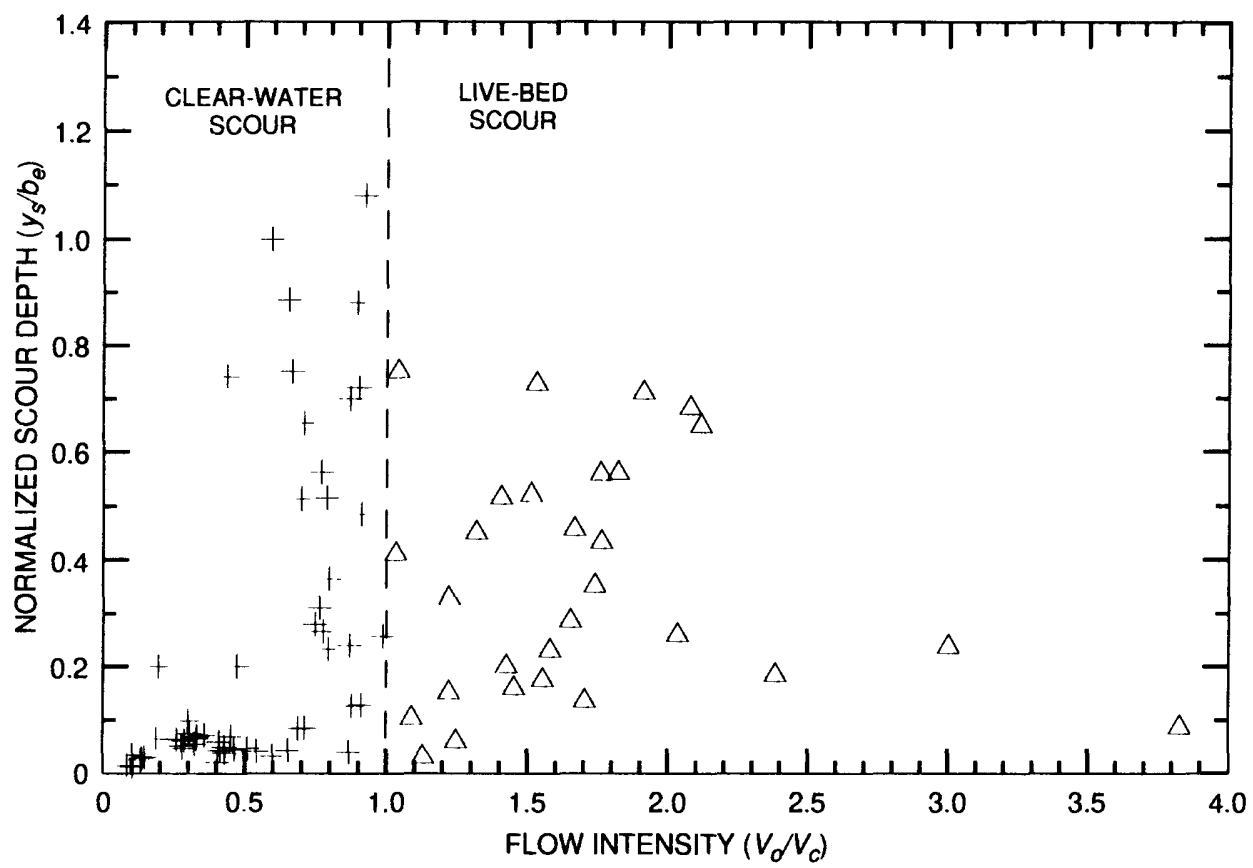

EXPLANATION

+ ClEAR-WATER DATA

$\triangle$ LIVE-BED DATA

Figure 16. Relation of normalized scour depth to flow intensity at bridge-scour study sites in Ohio.

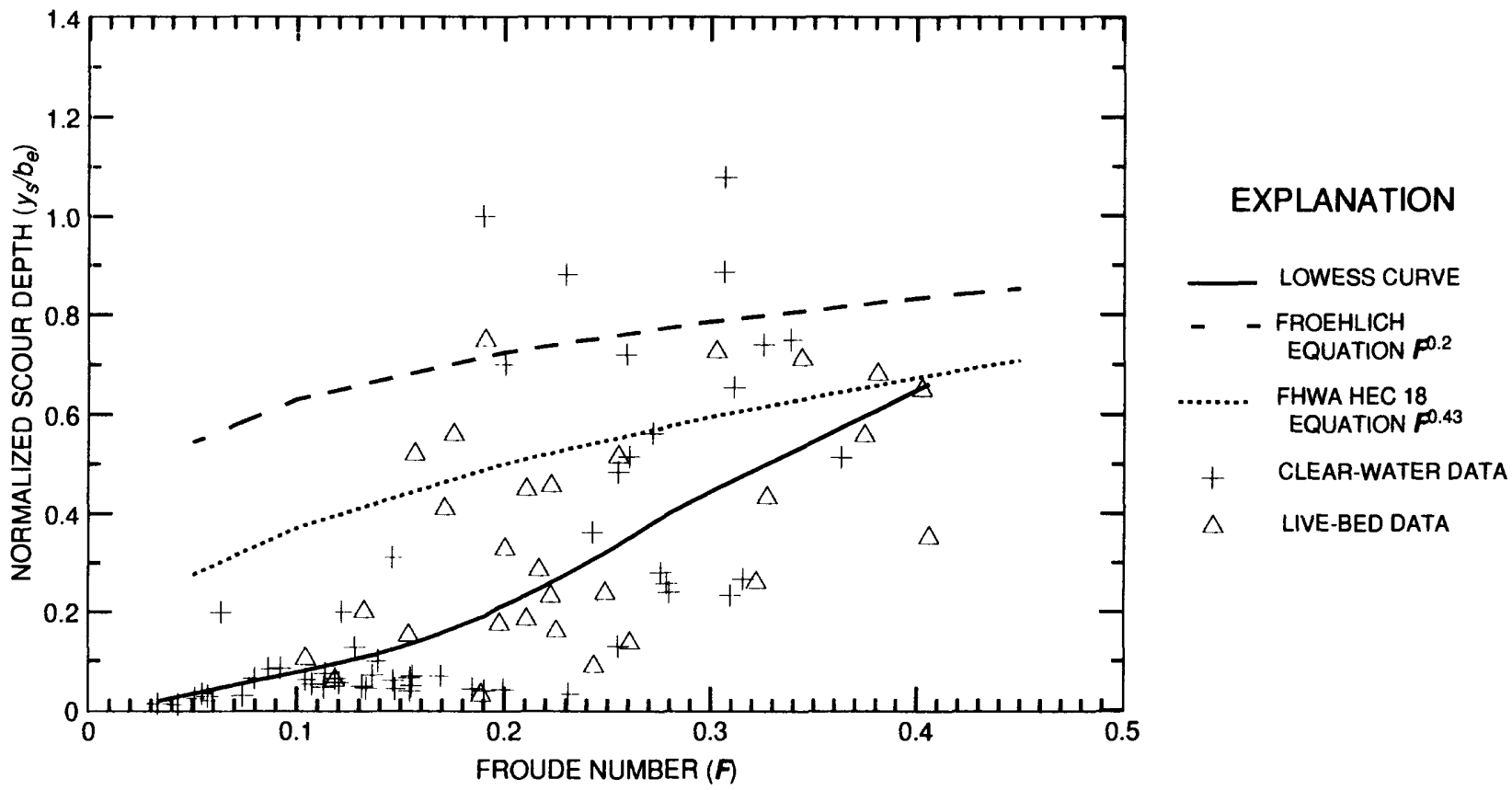

Figure 17. Relation of normalized scour depth to Froude number at bridge-scour study sites in Ohio. 

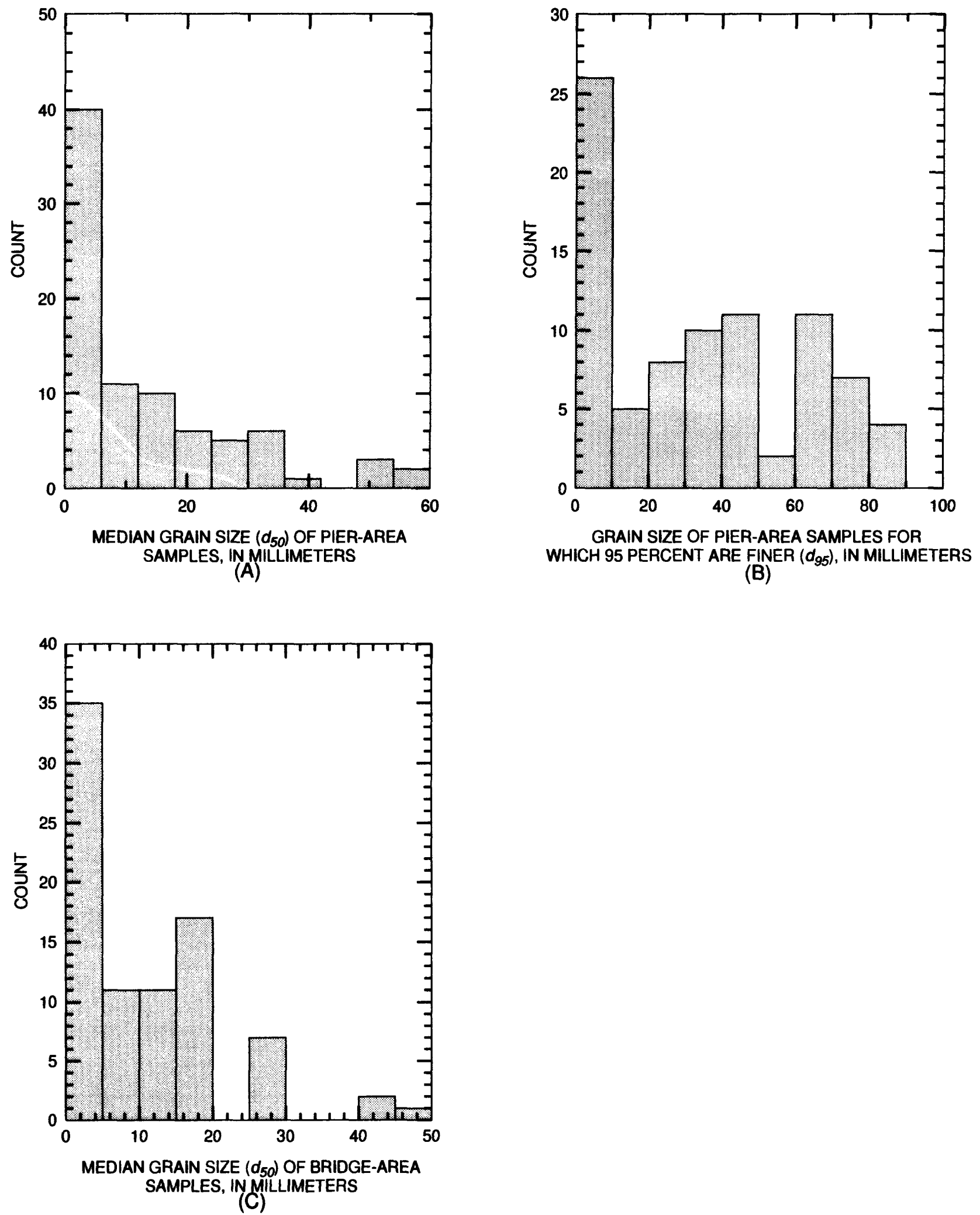

Figure 18. Histograms of selected bed-material samples from bridge-scour study sites in Ohio: (A) median grain size $\left(d_{50}\right)$ of pier-area samples, $(B) d_{95}$ of pier-area samples, and $(C)$ median grain size of bridge-area samples. 


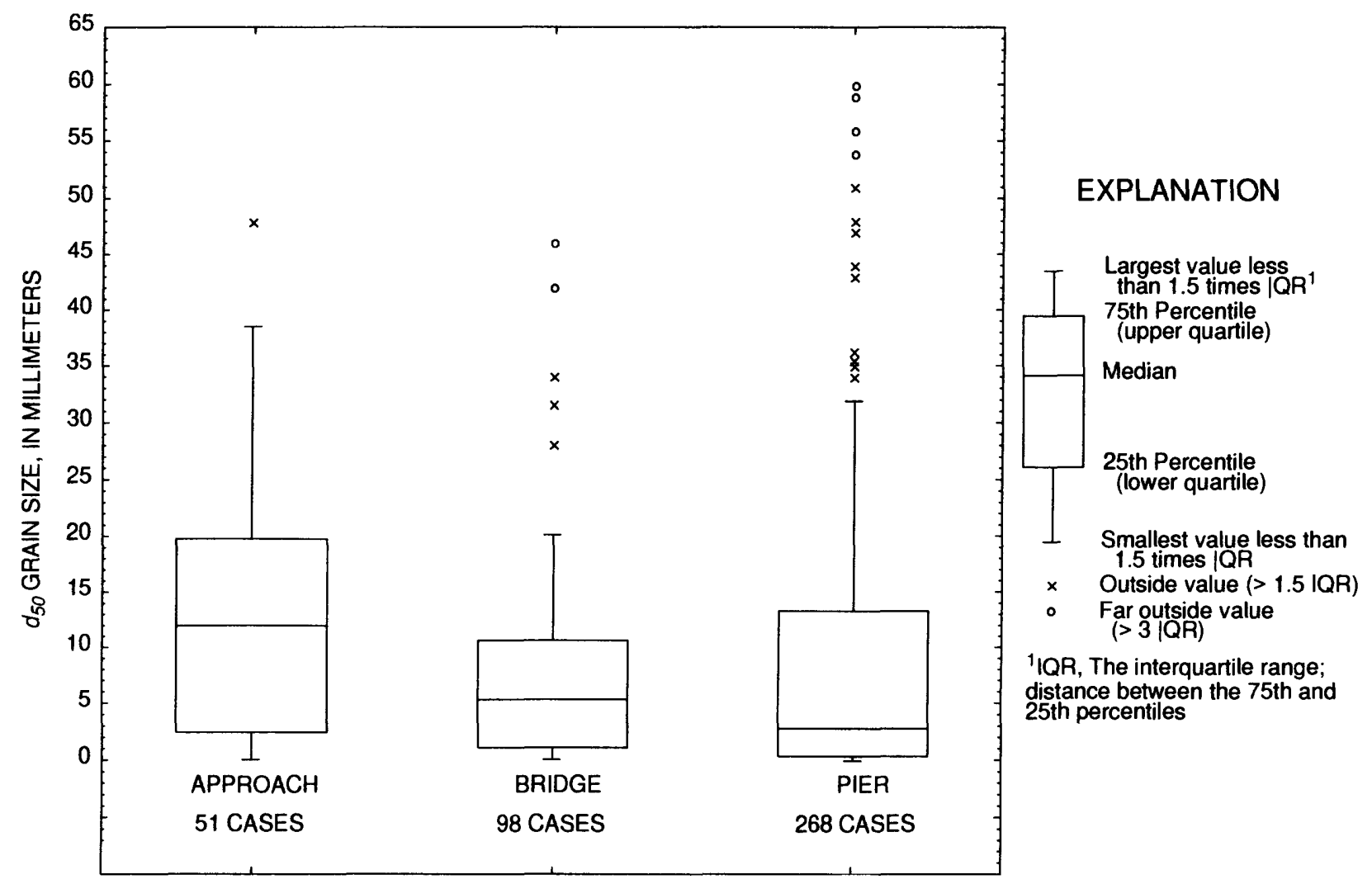

Figure 19. Boxplots of $d_{50}$ grain size for all bed-material samples collected at bridge-scour study sites in Ohio, identified by sampling-area location.

to the peak flow as logistically possible, but it is difficult to assess whether the scour measurements collected for this study were made under near-equilibrium conditions. Generally, experiments on pier scour in laboratory flume studies have been allowed to continue until equilibrium conditions are reached.

A scatterplot of the relation of pier-scour depth normalized by effective pier width $\left(y_{s} / b_{e}\right)$ to the ratio of pier width to median grain size of pier-area samples $\left(b / d_{50}\right)$ is shown in figure 21 for the 84 cases of pier scour in this study. No LOWESS curve is superimposed on this figure; however, two envelope functions are shown. One is the Melville and Sutherland (1988) sediment-size factor $K_{d}$ where $K_{d}=0.57 \log \left(2.24\left(b / d_{50}\right)\right)$ for $b / d_{50}<25$ and $K_{d}=1$, for $b / d_{50}>25$. The other is $\left(b / d_{50}\right)^{0.08}$, a term in Froehlich's (1988) pier-scour prediction equation that accounts for the relative sediment size. Melville and Sutherland's sediment size factor $K_{d}$ envelops most of the data points; however, one clear-water data point lies above Melville and Sutherland's sediment size factor $K_{d}$. All the data points observed in this investigation lie below the representation of the Froehlich equation's relative sediment size term of $\left(b / d_{50}\right)^{0.08}$. Both of these functions provide an approximate upper envelope for the observed scour data measured in Ohio.

A scatterplot of the relation of pier-scour depth normalized by effective pier width $\left(y_{s} / b_{e}\right)$ to pierarea samples grain size for which 95 percent are finer $\left(d_{95}\right)$ is shown in figure 22 for the 84 cases of pier scour in this study. The shape of the LOWESS curve indicates three trends: a slowly increasing trend for $d_{95}$ values of 0.1 to $10 \mathrm{~mm}$, a more rapidly increasing trend for $d_{95}$ values between $10 \mathrm{~mm}$ and 30 $\mathrm{mm}$, and then a rapidly decreasing trend above a $d_{95}$ value of $30 \mathrm{~mm}$. The increasing trends indicated by the LOWESS curve for $d_{95}$ values less than $30 \mathrm{~mm}$ also conflicts with previous research findings 


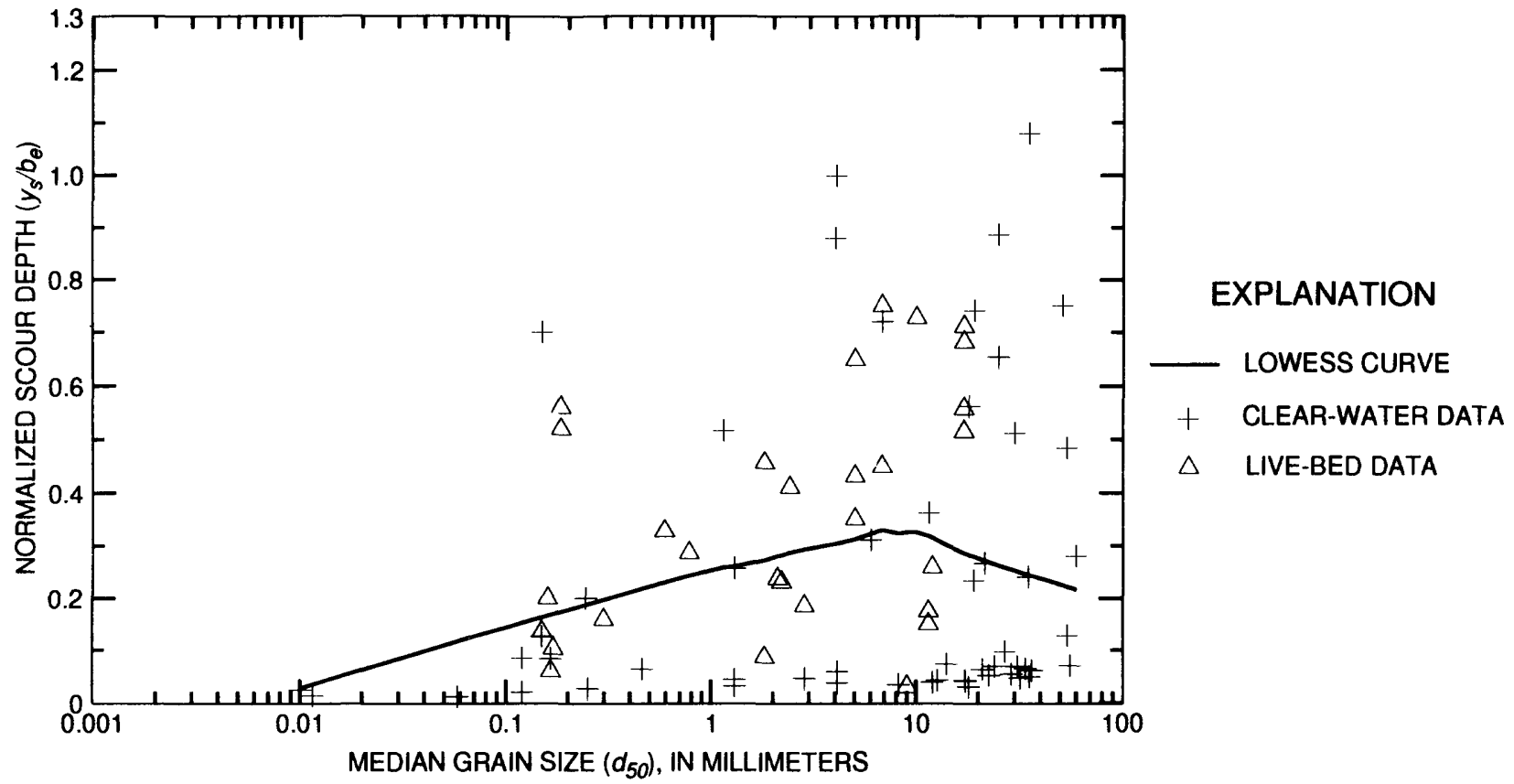

Figure 20. Relation of normalized scour depth to median grain size of pier-area samples at bridge-scour study sites in Ohio.

(that scour depth decreases with increasing sediment size). The apparent threshold of $d_{95}>30 \mathrm{~mm}$ is generally consistent with findings by Mueller (1996), using scour data collected in the field, that indicate a decrease in scour depth for $d_{95}>20 \mathrm{~mm}$.

Sediment gradation. Stream sediments commonly are composed of a nonuniform mixture of a wide range of particle sizes. A commonly used measure of sediment gradation is the geometric standard deviation of the bed-material particle-size distribution $(\sigma)$, defined as

$$
\sigma=\sqrt{d_{84} / d_{16}}
$$

where

$d_{84}$ is grain size for which 84 percent are finer and

$d_{16}$ is grain size for which 16 percent are finer.

The relation of pier-scour depth normalized by effective pier width $\left(y_{s} / b_{e}\right)$ to geometric standard deviation of the particle-size distribution for pier-area samples $(\sigma)$ is shown in figure 23 . Only 81 cases are presented in this scatterplot because no data were available to compute the geometric standard deviation for three bed-material samples. The trend of the LOWESS curve indicates that normalized scour depth decreases rapidly as $\sigma$ increases to about 3 and then decreases more slowly as $\sigma$ increases further. For the data in this study, the trend of the LOWESS curve tends to support the conclusion that scour depth is reduced as sediment gradation increases.

\section{Analysis of Cases of Observed Pier-Scour Data with Approach-flow Attack Angles of 10 Degrees or Less}

Research by Laursen and Toch (1956) demonstrated that as the approach-flow attack angle increases, the location of the deepest point of scour migrates from the upstream face of the pier towards an area along the side of the pier. Because scour depths were measured at the upstream face of piers in this study, maximum scour depths may not have been measured at piers appreciably misaligned with the flow. 


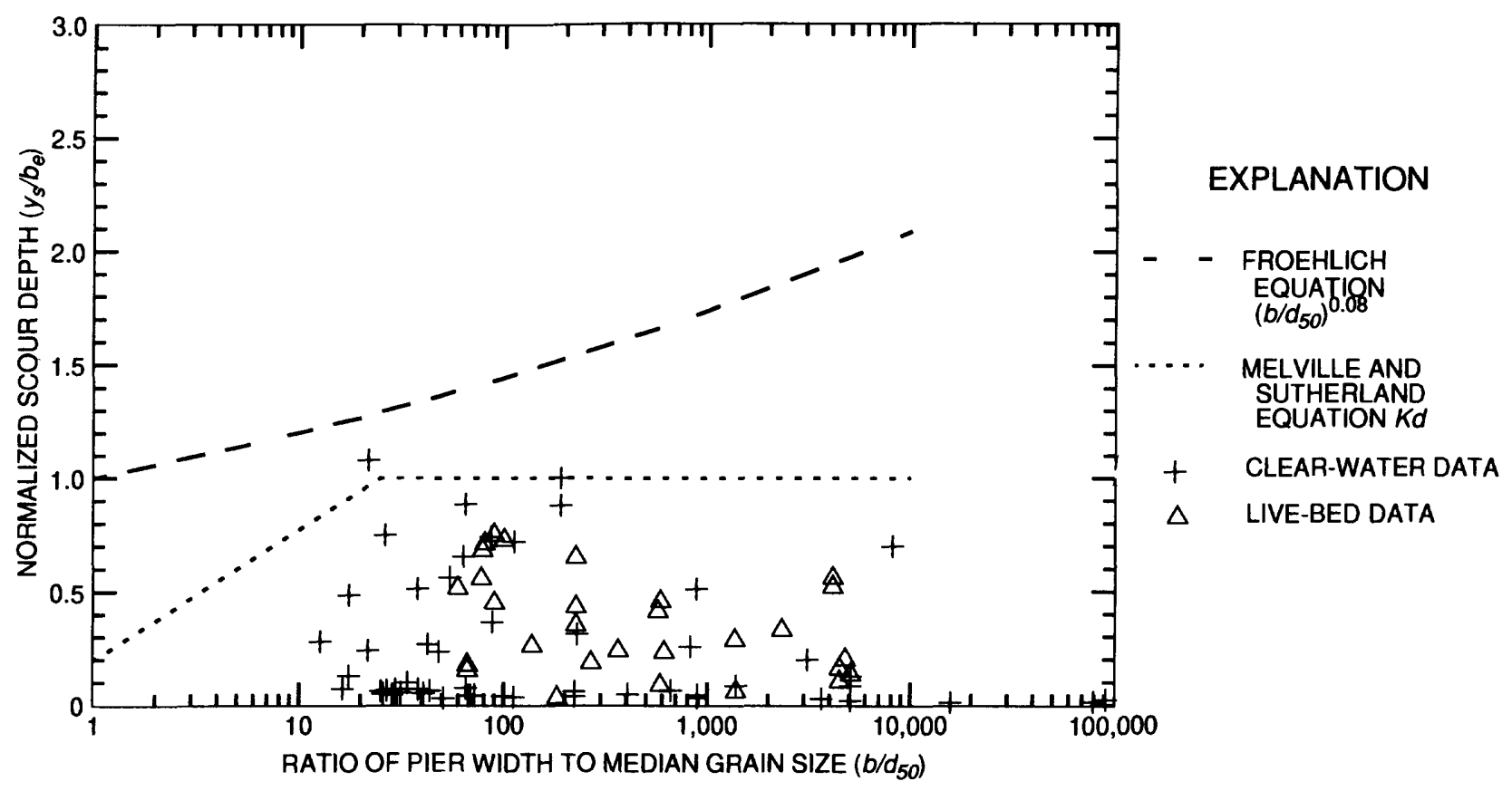

Figure 21. Relation of normalized scour depth to the ratio of pier width to median grain size of pier-area samples at bridge-scour study sites in Ohio.

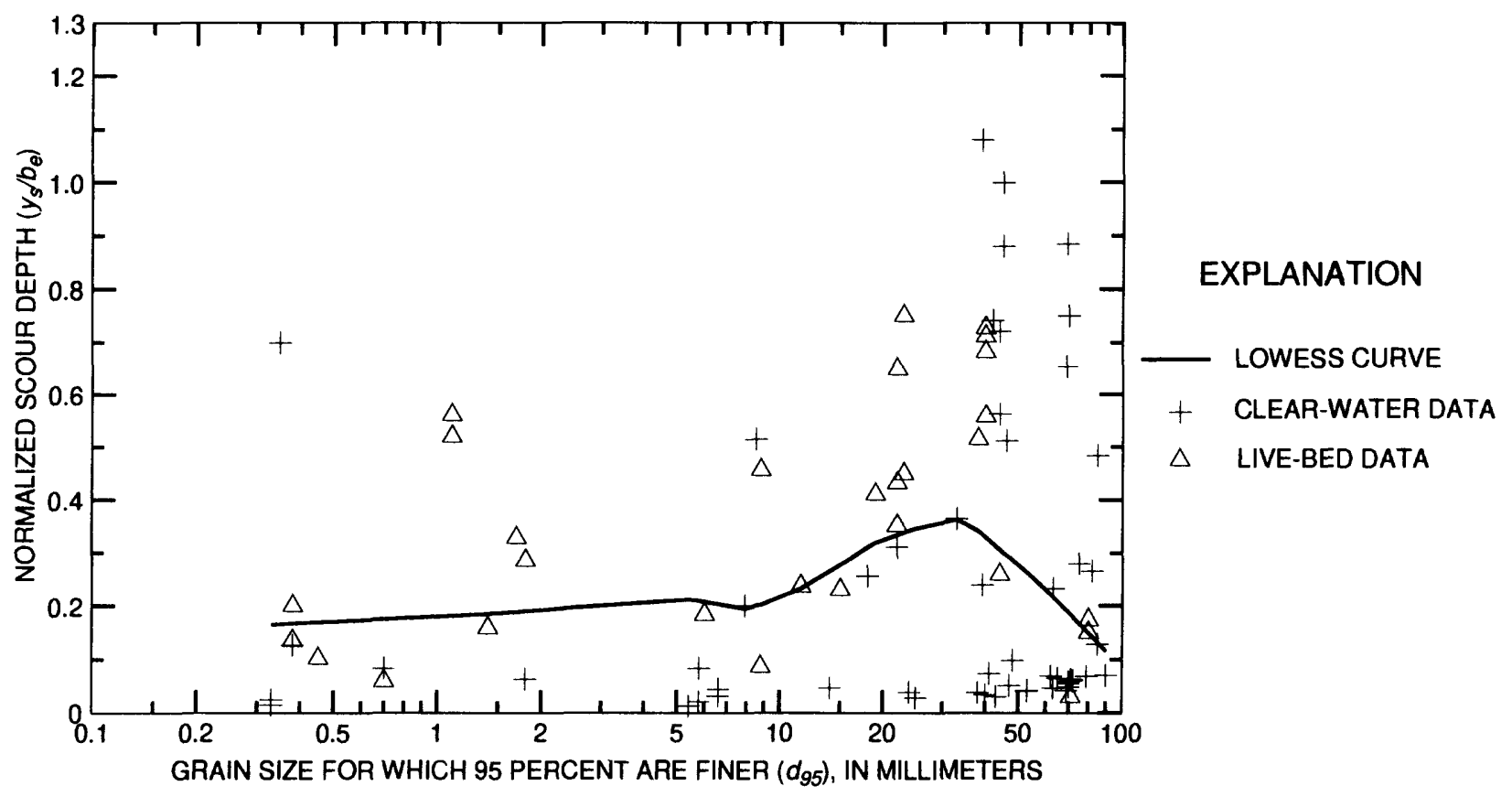

Figure 22. Relation of normalized scour depth to $d_{95}$ of pier-area samples from bridge-scour study sites in Ohio. 


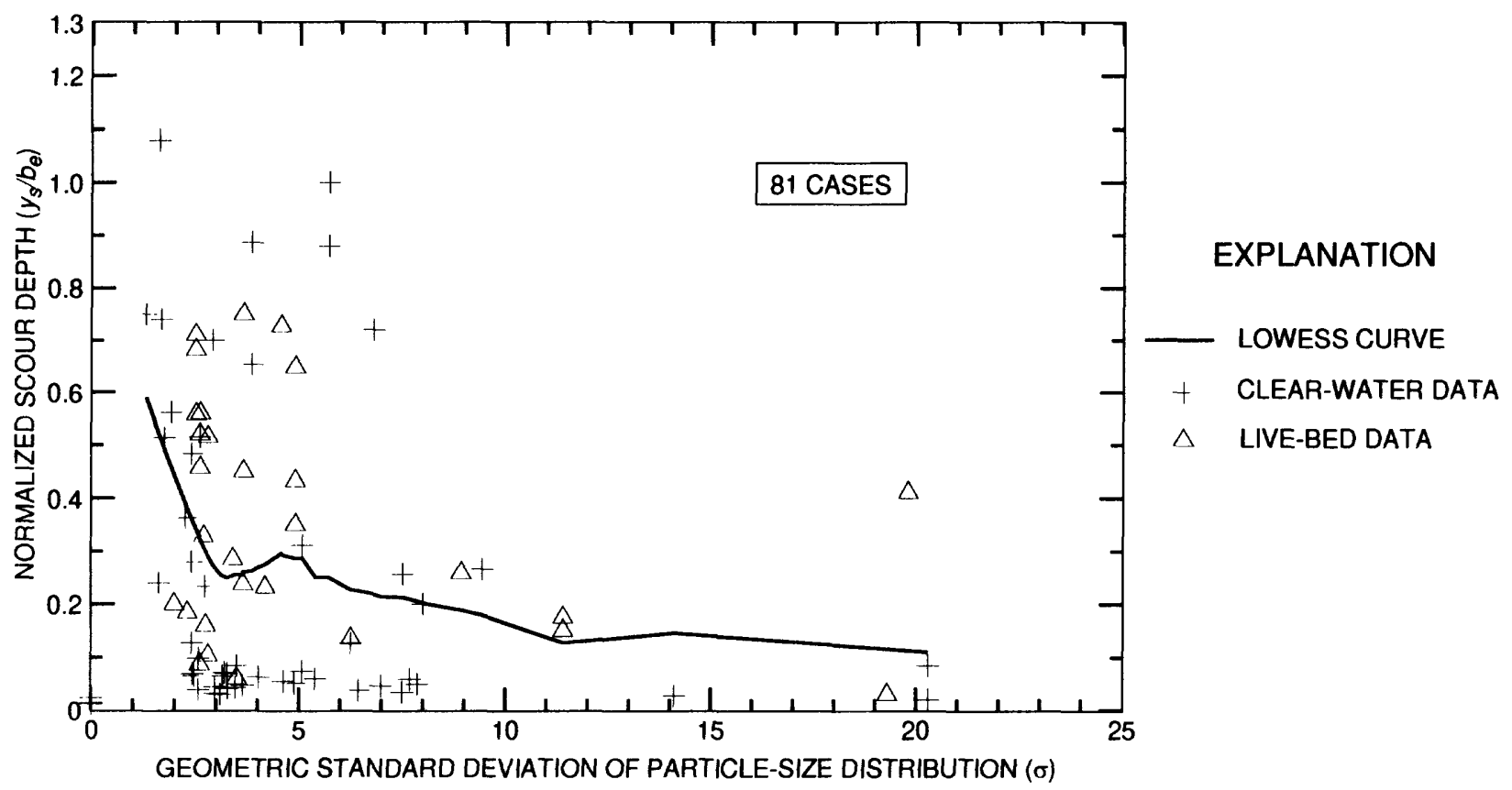

Figure 23. Relation of normalized scour depth to the geometric standard deviation of particle-size distribution for pier-area samples from bridge-scour study sites in Ohio.study sites in Ohio.

In order to assess the influence of attack angle on the previously developed LOWESS curves, new LOWESS curves were developed by use of only those observations of pier scour where the approachflow attack angle $(\alpha)$ was less than or equal to 10 degrees $\left(\alpha \leq 10^{\circ}\right)$. Of the 84 total cases of observed pier scour, 45 occurred at piers where $\alpha \leq 10^{\circ}$. The LOWESS curves developed from data for piers with $\alpha \leq 10^{\circ}$ were visually compared to those that had been developed from all observations of pier scour. Three of the previously discussed relations were judged to result in differences in LOWESS curves of sufficient magnitude to warrant further discussion. The LOWESS curves developed from data for piers with $\alpha \leq 10^{\circ}$ have been added to the plots of those three relations, and they are discussed in further detail below. For the remaining four relations, LOWESS curves developed from data for piers with $\alpha \leq 10^{\circ}$ were judged to be indicative of the same general trends as the LOWESS curves developed from all observations of pier scour.

Relation of pier-scour depth $\left(y_{s}\right)$ to effective pier width $\left(b_{e}\right)$. The LOWESS curve developed from data for piers with $\alpha \leq 10^{\circ}$ (fig. 11) rises steeply to an effective pier width of about $5 \mathrm{ft}$ and then declines steeply to an effective pier width of about $7 \mathrm{ft}$; at this point, it continues to decline, but with a much gentler slope. In contrast, the LOWESS curve developed from all observations of pier scour is much flatter, and its inflection points are at different values of effective pier width. The LOWESS curve developed from data for piers with $\alpha \leq 10^{\circ}$ spans a shorter range than the LOWESS curve developed from all observations of pier scour because the smaller attack angles resulted in a more limited range of effective pier widths.

Relation of pier-scour depth $\left(y_{s}\right)$ to flow depth $\left(y_{o}\right)$. The trend of the LOWESS curve reflecting the data for piers with $\alpha \leq 10^{\circ}$ (fig. 13) is generally consistent with the LOWESS curve for all observations between flow-depth values of about 6 and $13.5 \mathrm{ft}$. However, for flow depths less than $6 \mathrm{ft}$, the LOWESS curve for the $\alpha \leq 10^{\circ}$ data indicates a decreasing relation that contrasts with the increasing relation indicated by the LOWESS curve for all observations. For flow depths exceeding $13.5 \mathrm{ft}$, the LOWESS curve for the $\alpha \leq 10^{\circ}$ data increases more rapidly than the LOWESS curve for all observations. 
Relation of normalized scour depth $\left(y_{s} / b_{e}\right)$ to normalized flow depth $\left(y_{o} / b_{e}\right)$. The trend of the LOWESS curve developed from data for piers with $\alpha \leq 10^{\circ}$ (fig. 14) indicates that $y_{s} / b_{e}$ increases with $y_{o} / b_{e}$ up to about 2.6 and then decreases for larger values of $y_{o} / b_{e}$. The decreasing trend of the LOWESS curve for the $\alpha \leq 10^{\circ}$ data contrasts with the increasing trend of the LOWESS curve for all observations for $y_{o} / b_{e}$ greater than 2.6. The trend of the LOWESS curve developed from data for piers with $\alpha \leq 10^{\circ}$ also provides some support to Melville and Sutherland's conclusion (1988) that scour depth increases up to a limiting value of 3 for the ratio of flow depth to pier width.

\section{Predicted Scour at Bridge Piers}

Analyses discussed in this section compare estimates of pier-scour depth generated by use of selected pier-scour prediction equations with observed pier-scour depths. The pier-scour prediction equations are then evaluated to determine which equations most closely meet "best design equation" criteria.

\section{Comparison of Predicted and Observed Pier Scour}

Seventeen published pier-scour equations, described in detail in the appendix, were selected and used to compute values of predicted pier-scour depth. The selected equations were originally developed to predict either the equilibrium, maximum, or design depth of pier scour. However, for the comparisons made in this investigation, all the equations are treated as design equations and are compared on that basis. An ideal design pier-scour equation should accurately predict maximum scour depth, and when in error, should tend towards overestimation of scour depth. Two analyses were done to compare the values of predicted and observed pier-scour depths. The first analysis is based upon all the cases of observed pier scour. The second analysis restricts the cases of observed pier scour to those where the approach-flow attack angle was 10 degrees or less $\left(\alpha \leq 10^{\circ}\right)$. The second analysis was done to determine when the results would differ from the first analysis by restricting the data to smaller attack angles.

\section{Comparison Using All Cases of Observed Scour}

The hydraulic conditions for 84 observations of pier scour were used as input data for the 17 pierscour prediction equations to produce estimates of pier-scour depth. Because of restrictions on median bed-material size and velocity input-data values for the appropriate use of the Arkansas pier-scour equation (as discussed in the appendix), this equation could be applied to only 66 of the 84 cases of observed pier scour. Scatterplots of the relation of predicted and observed pier-scour depths for each of the 17 selected equations are shown in figures 24 through 28 . To assist in the interpretation of the data, a "line of equality" representing equal values of predicted and observed pier scour depth is shown on each of the plots. Data points lying above the line of equality represent observations where the predicted scour depth exceeded the observed scour depth (overpredictions). Points lying below the line of equality represent observations where the predicted scour depth was less than the observed scour depth (underpredictions). These scatterplots indicate that most of the equations considerably overpredict scour depth and the data in many of the plots do not exhibit a trend that would approximate the line of equality.

Boxplots of the predicted scour depths for all 17 equations and the observed pier-scour depth data are shown in figure 29. The boxplots indicate that, in general, most of the equations overestimate pierscour depth compared to the observed data. In contrast, five of the equations (Ahmad, Blench-Inglis II, 
AHMAD

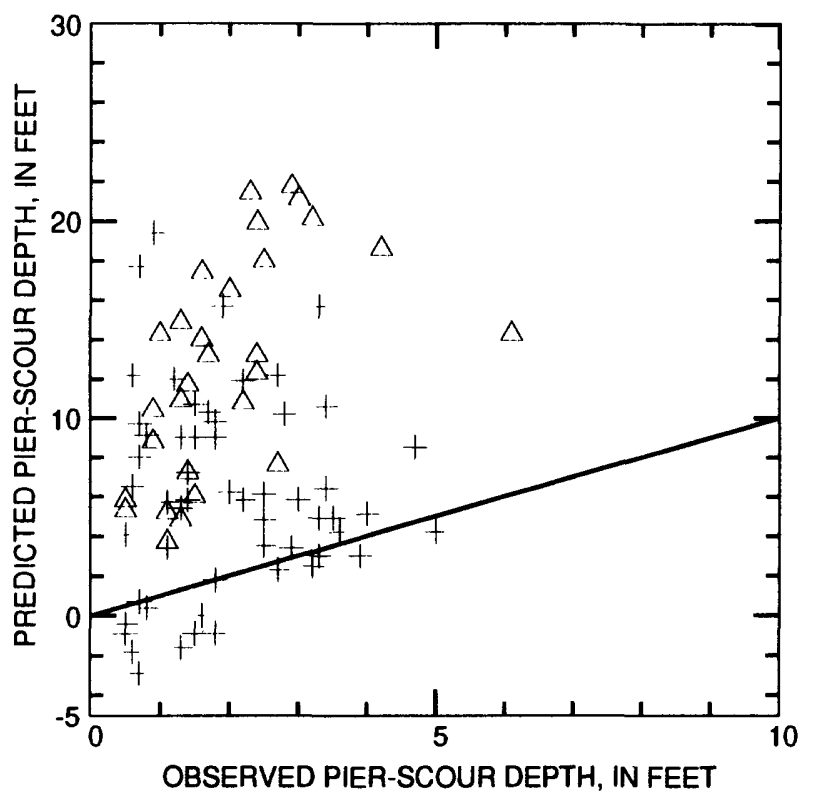

BLENCH-INGLIS I

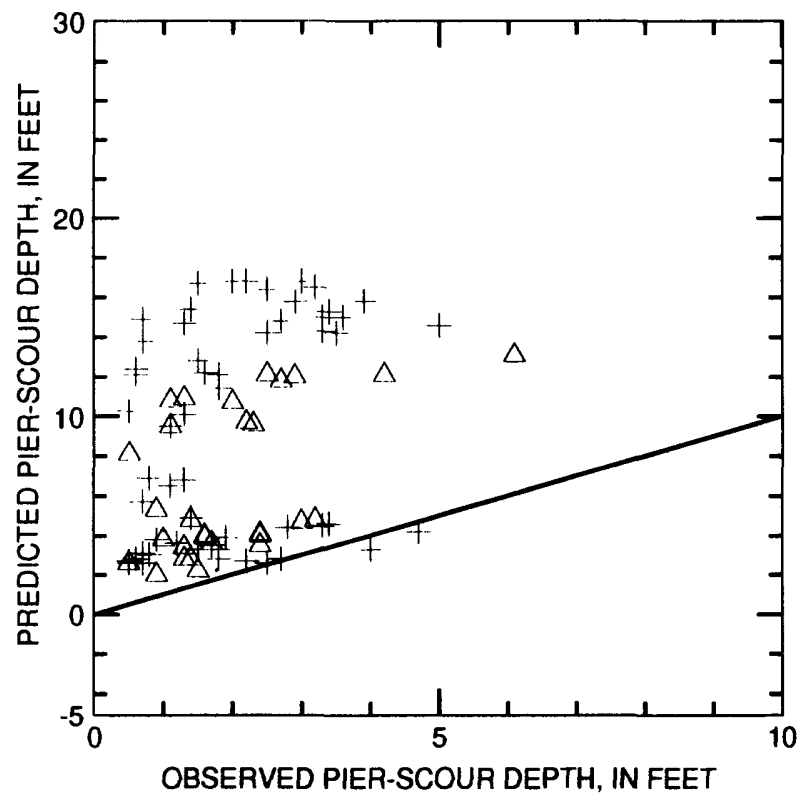

ARKANSAS

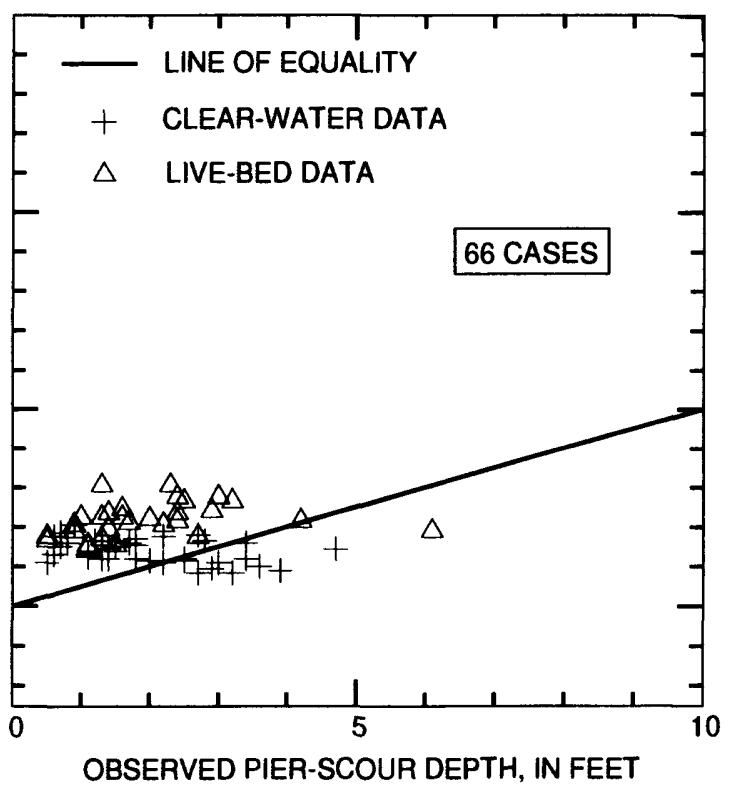

BLENCH-INGLIS II

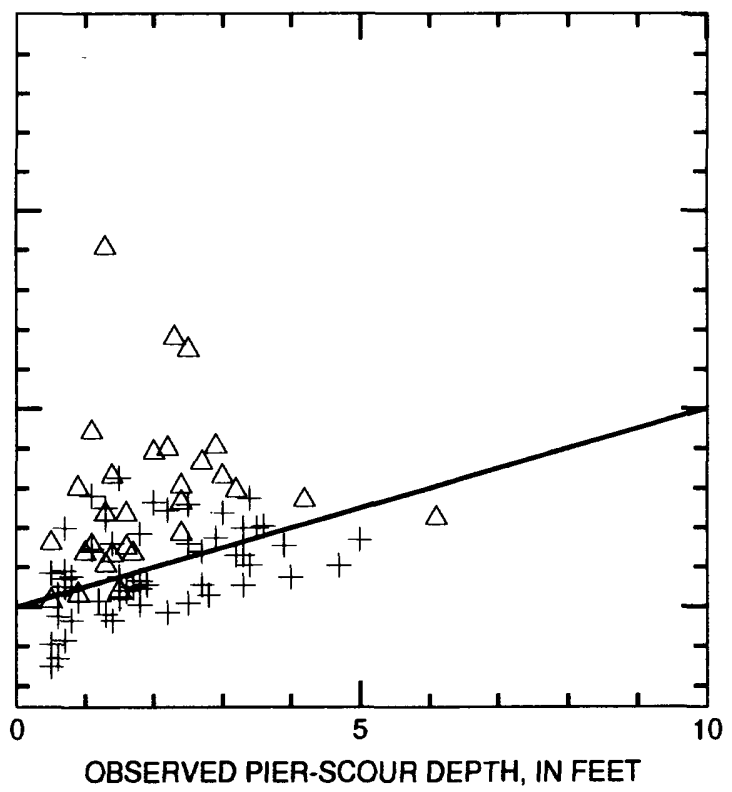

Figure 24. Relation of predicted pier-scour depths from the Ahmad, Arkansas, Blench-Inglis 1, and Blench-Inglis II equations to scour depths observed at bridge-scour study sites in Ohio. 
CHITALE

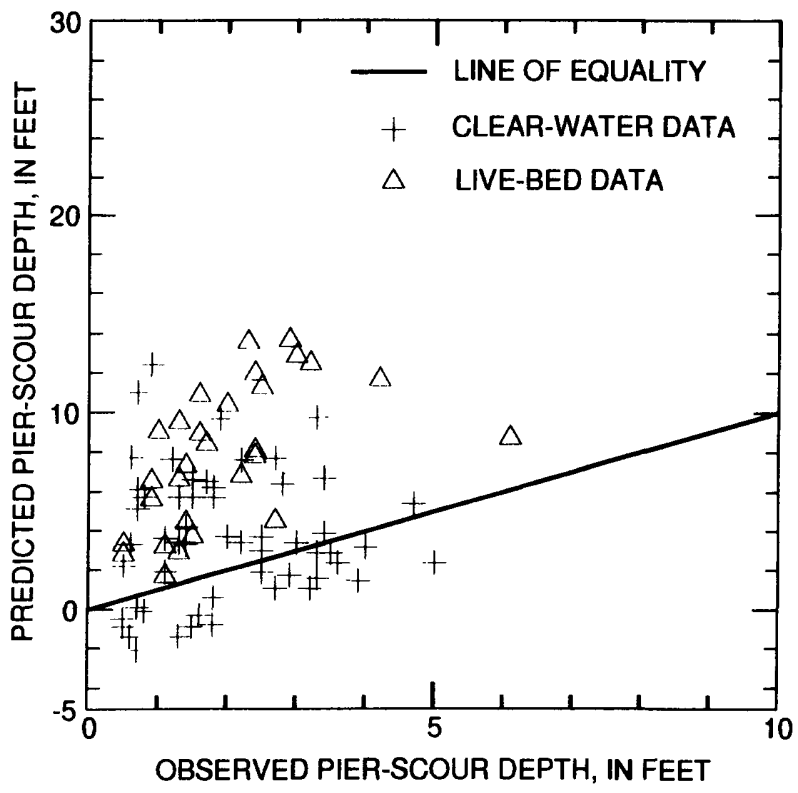

FROEHLICH

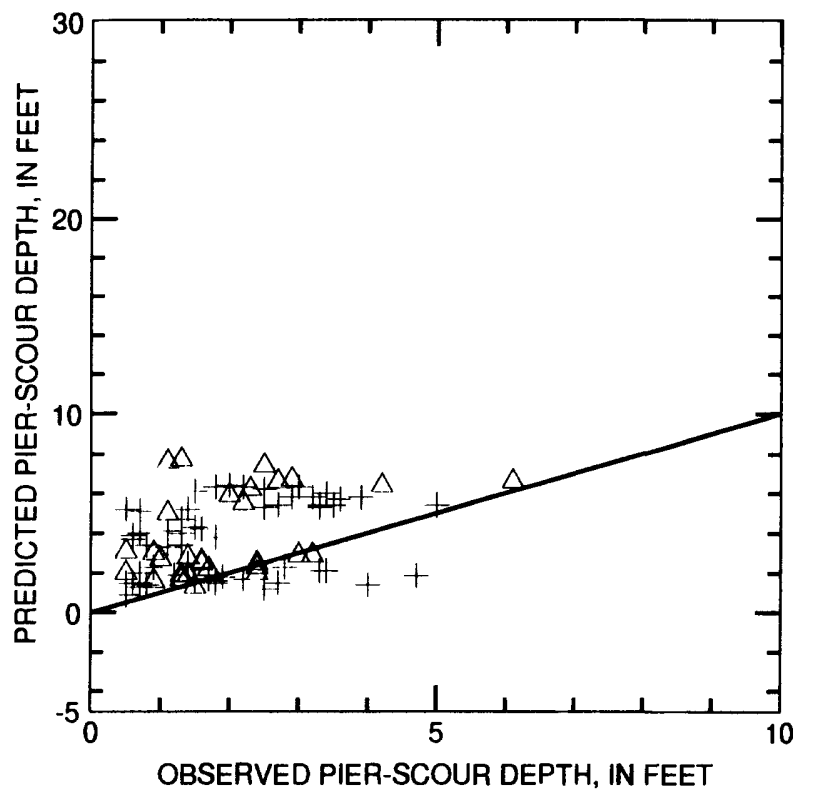

FHWA HEC 18

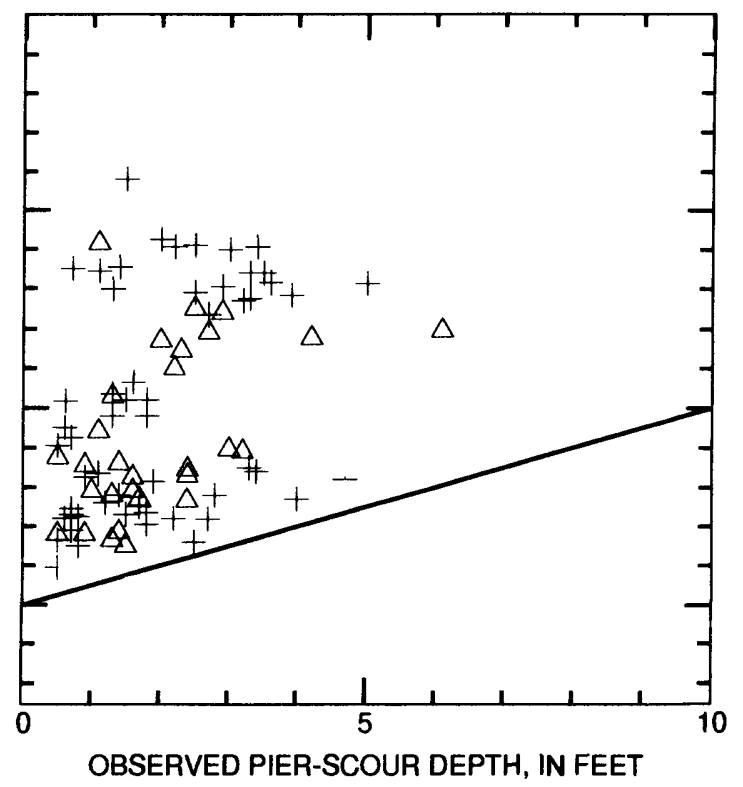

FROEHLICH DESIGN

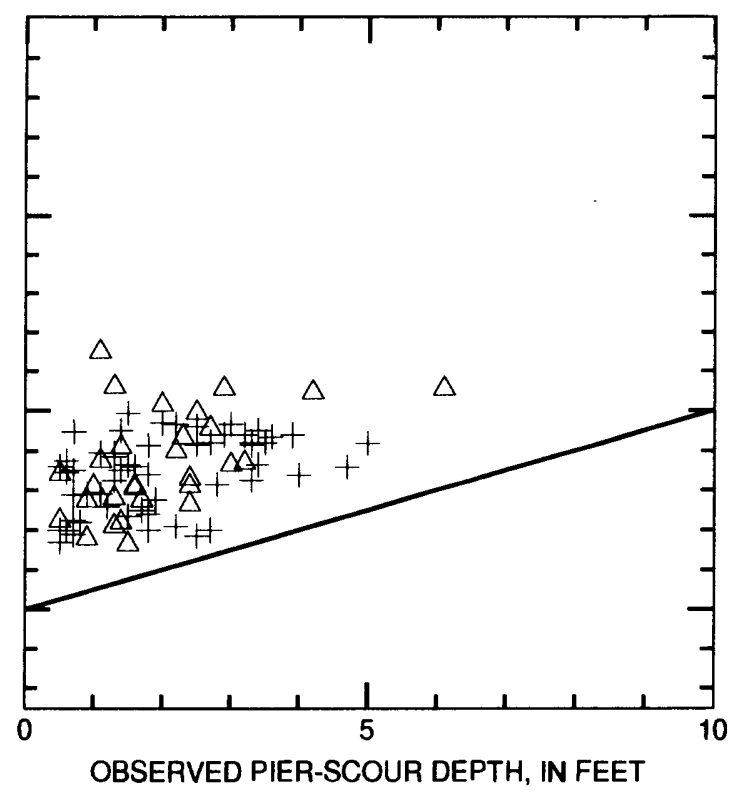

Figure 25. Relation of predicted pier-scour depths from the Chitale, FHWA HEC 18, Froehlich, and Froehlich Design equations to scour depths observed at bridge-scour study sites in Ohio. 
INGLIS-LACEY

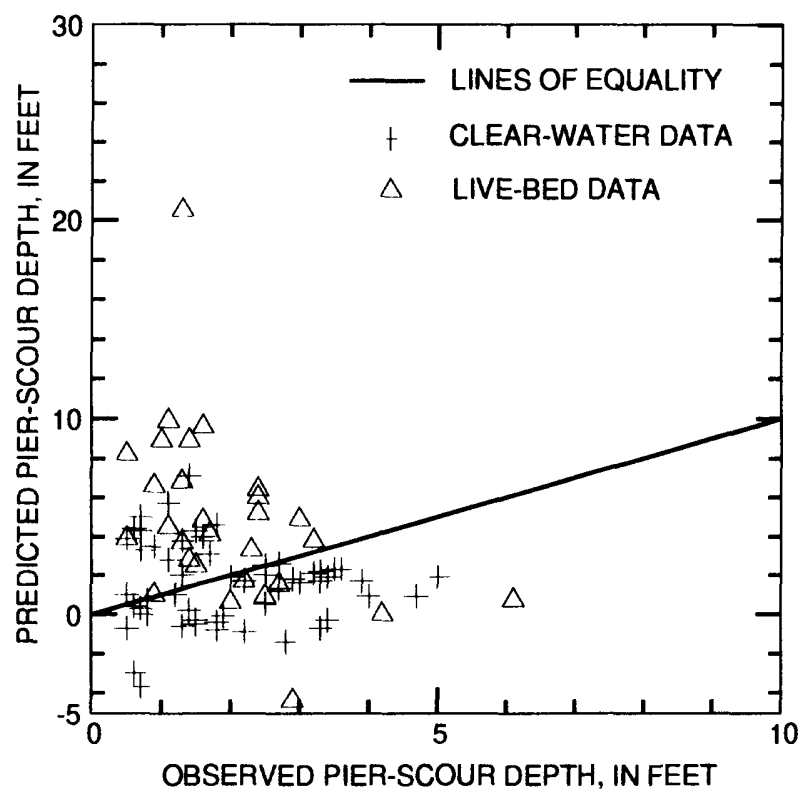

INGLIS-POONA ||

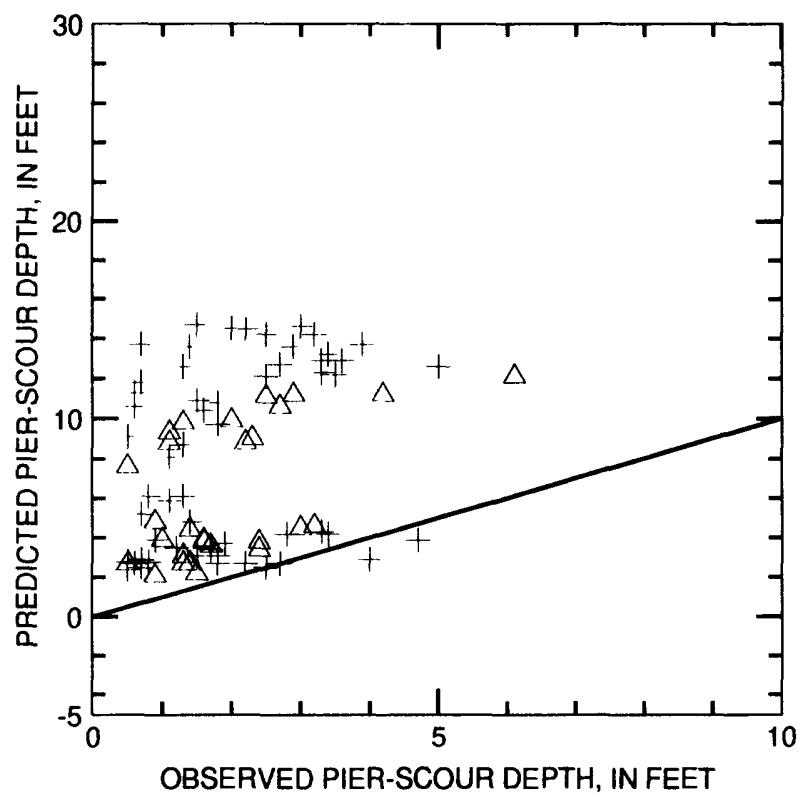

INGLIS-POONA I

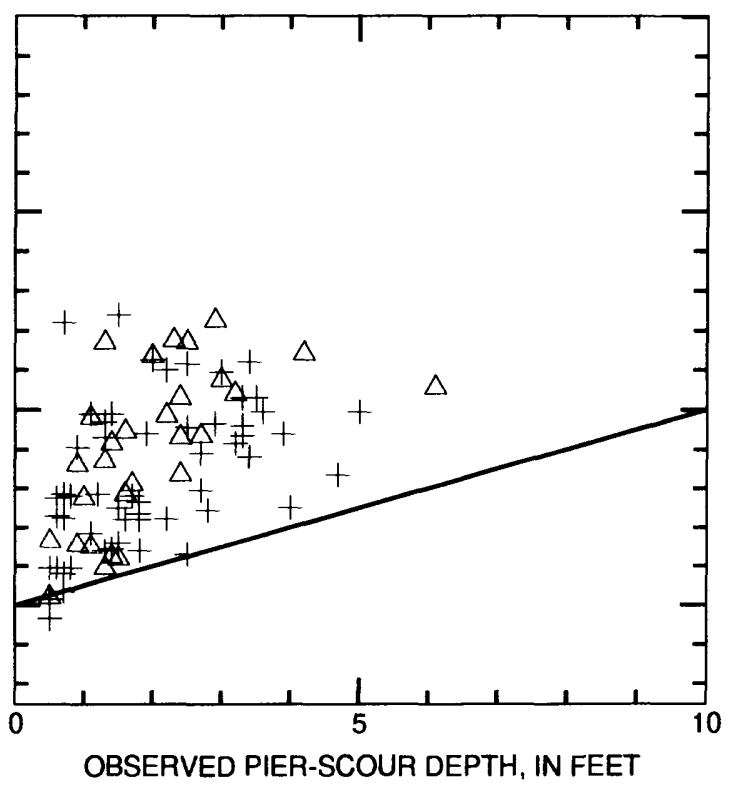

LARRAS

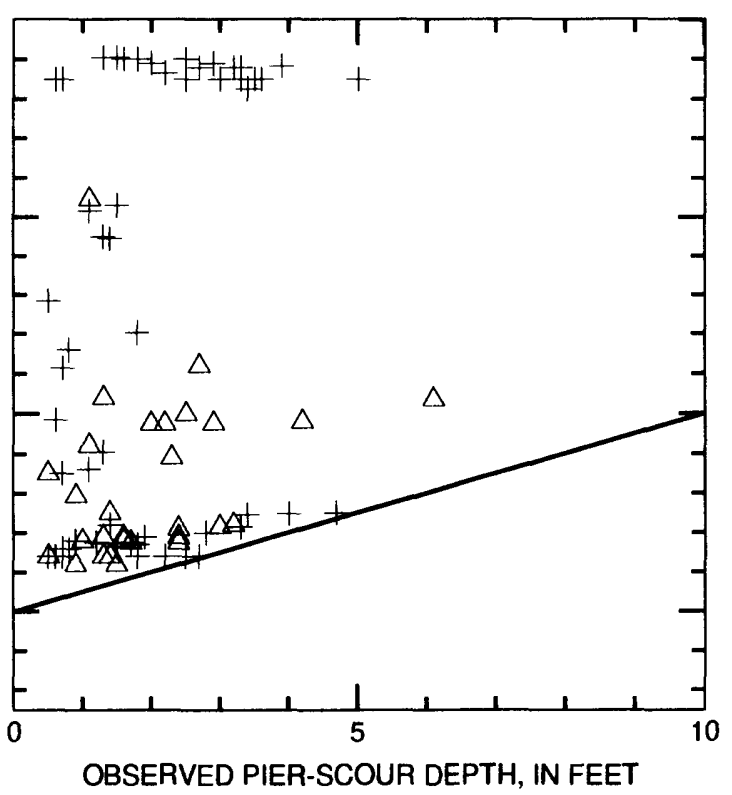

Figure 26. Relation of predicted pier-scour depths from the Inglis-Lacey, Inglis-Poona I, Inglis-Poona II, and Larras equations to scour depths observed at bridge-scour study sites in Ohio. 
LAURSEN
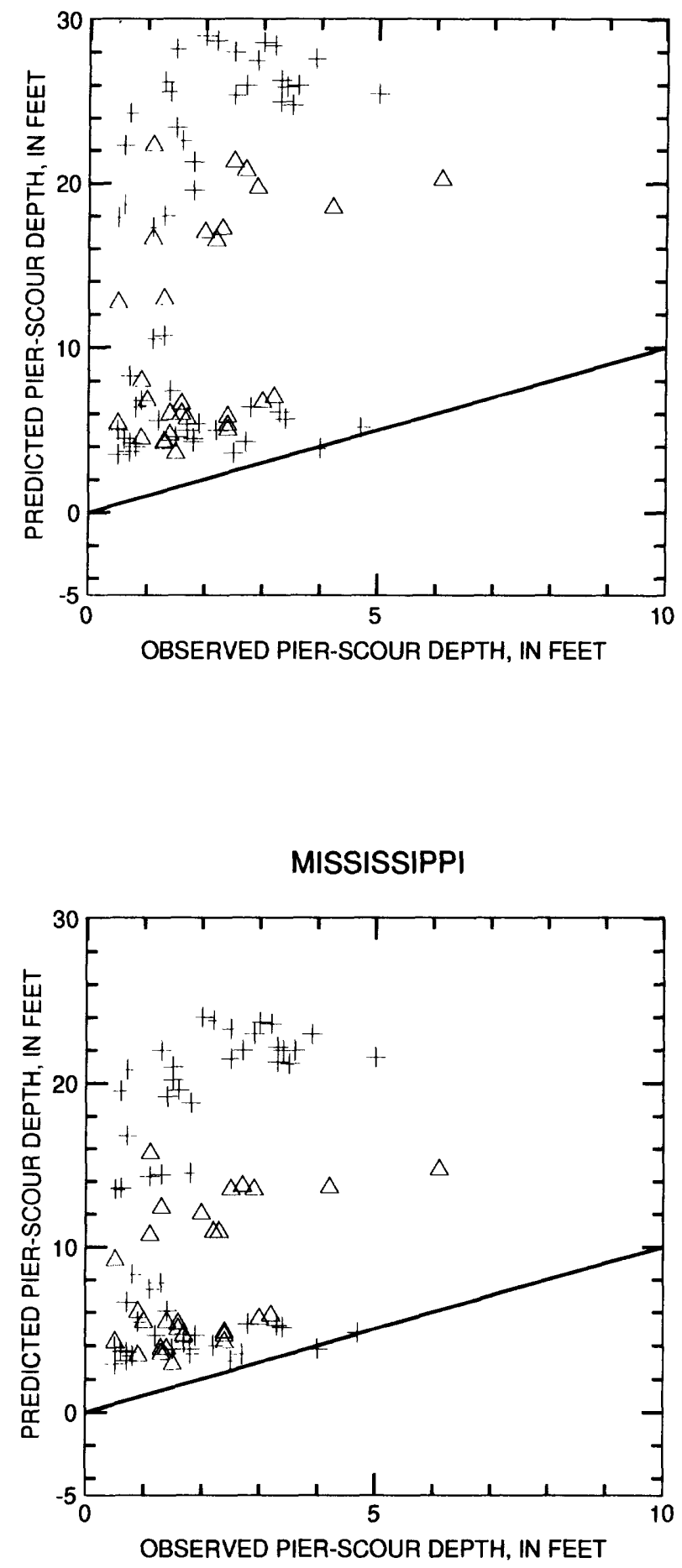

MELVILLE AND SUTHERLAND

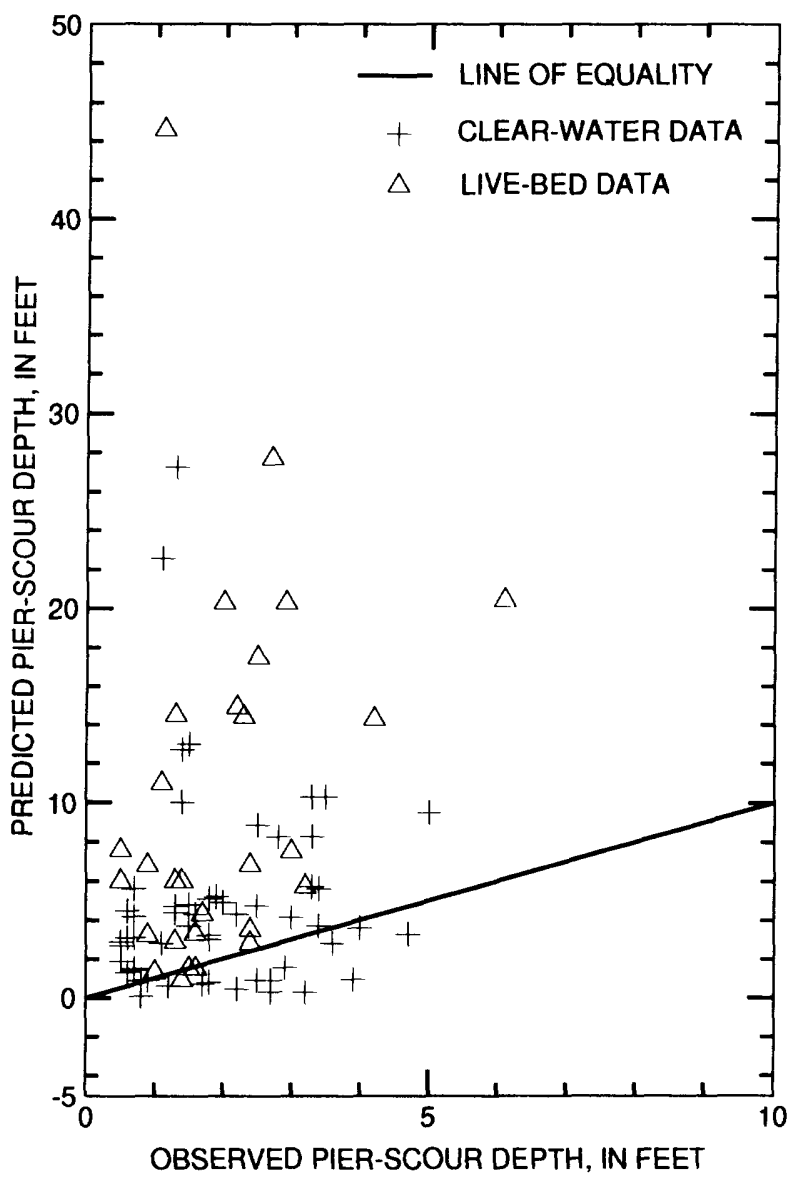

Figure 27. Relation of predicted pier-scour depths from the Laursen, Melville and Sutherland, and Mississippi equations to scour depths observed at bridge-scour study sites in Ohio. (Vertical scale for the Meville and Sutherland equation has been expanded to include the range of predicted data.) 

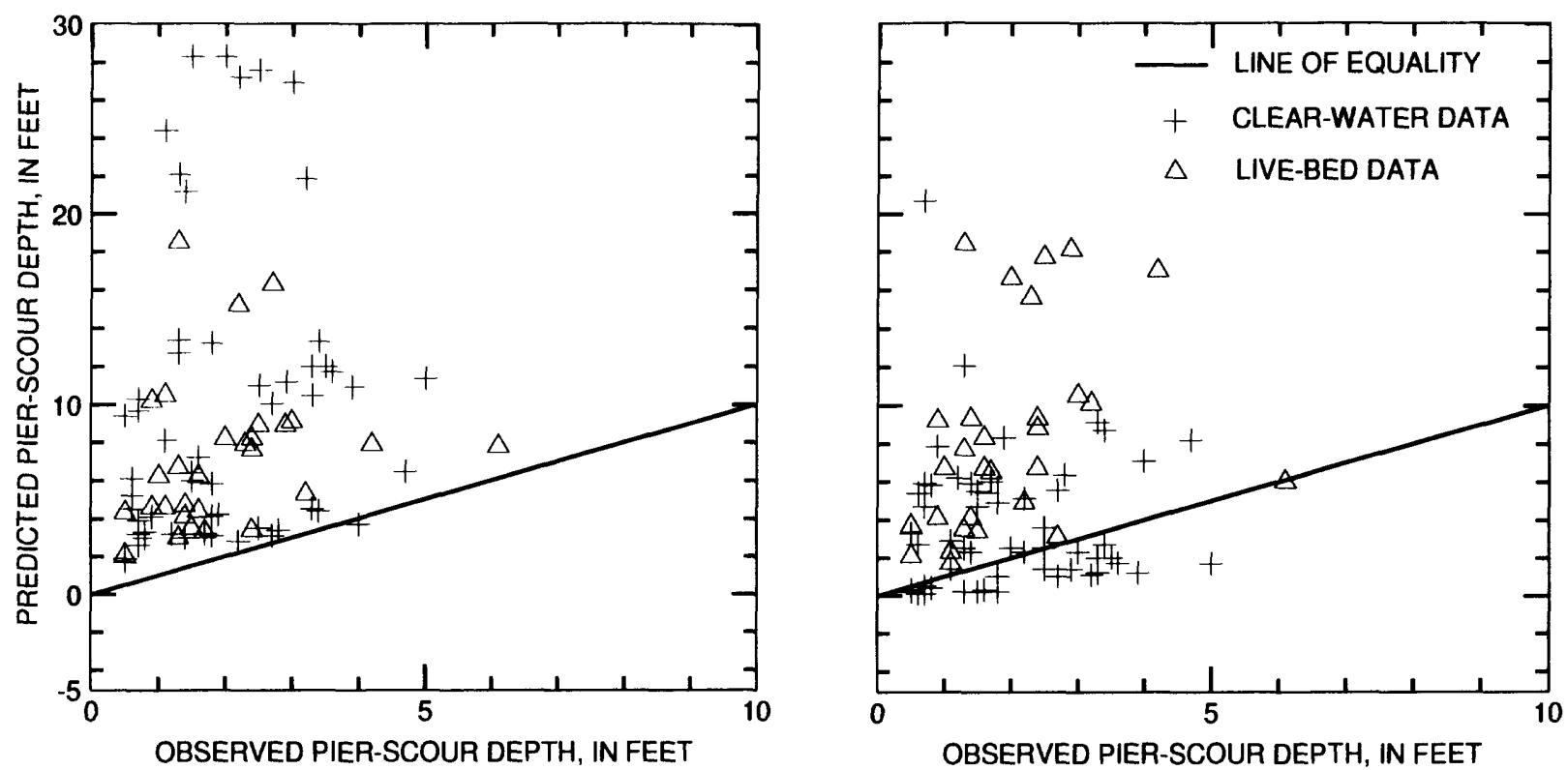

Figure 28. Relation of predicted pier-scour depths from the Shen and Shen-Maza equations to scour depths observed at bridge-scour study sites in Ohio.

Chitale, Inglis-Lacey, and Inglis-Poona I) predicted negative pier-scour depths for some of the input data.

Boxplots of the residuals (predicted scour depth minus the observed scour depth) for all the equations are shown in figure 30. The boxplots in this figure indicate that 14 of the 17 selected equations underestimate the scour depth (indicated by the lower whisker extending below the zero-residual line). The three equations that did not underestimate scour depths for the input-data set were the FHWA HEC 18, Froehlich Design, and Larras equations.

\section{Comparison Using Cases of Observed Scour with Approach-Flow Attack Angles of 10 Degrees or Less}

For this analysis, only cases of observed pier scour with approach-flow attack angles of 10 degrees or less were selected as input data for the 17 pier-scour prediction equations. This restriction resulted in 45 cases for analysis. Because of data restrictions, the Arkansas equation could be applied to only 40 of the 45 cases.

Boxplots of the predicted and the observed pier-scour depth data for this data set are shown in figure 31. These boxplots generally show much less variability for most of the equations compared to those developed from the full data set (fig. 29). Although less variability is evident for most of the equations, most of the equations still generally overestimate pier-scour depth for the observed data with approach-flow attack angles of 10 degrees or less. The Ahmad, Blench-Inglis II, Chitale, Inglis-Lacey, and Inglis-Poona I equations predicted negative pier-scour depths for some of the input data.

Boxplots of the residuals between the predicted and observed scour depths with approach-flow attack angles of 10 degrees or less are shown in figure 32. As with the full data set, 14 of the 17 selected equations occasionally underpredicted scour depth. Only the FHWA HEC 18, Froehlich Design, and Larras equations never underestimated scour depths. 


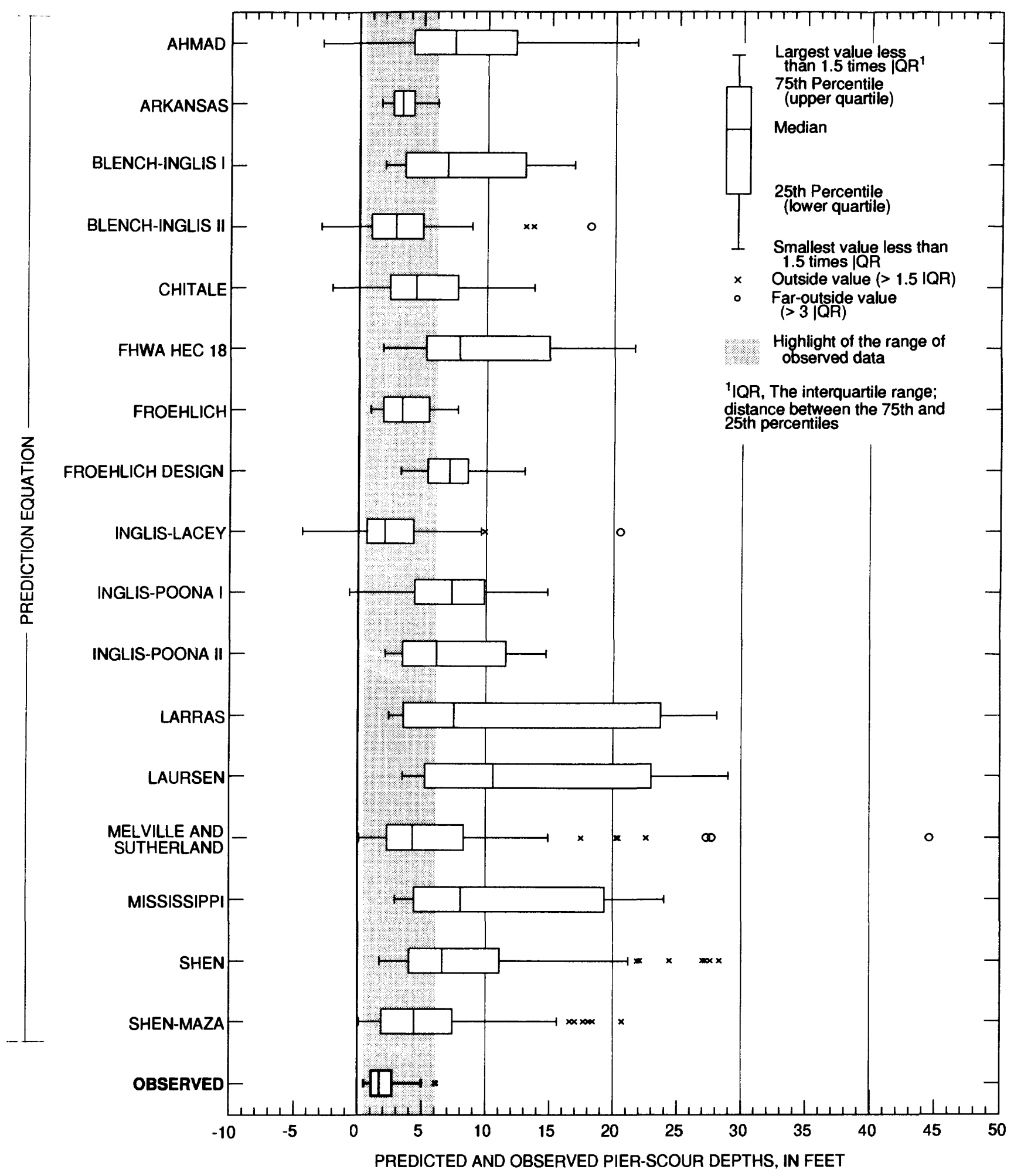

Figure 29. Distribution of predicted and observed pier-scour depths at bridge-scour study sites in Ohio. (Results for the Arkansas equation are based on 66 cases.) 


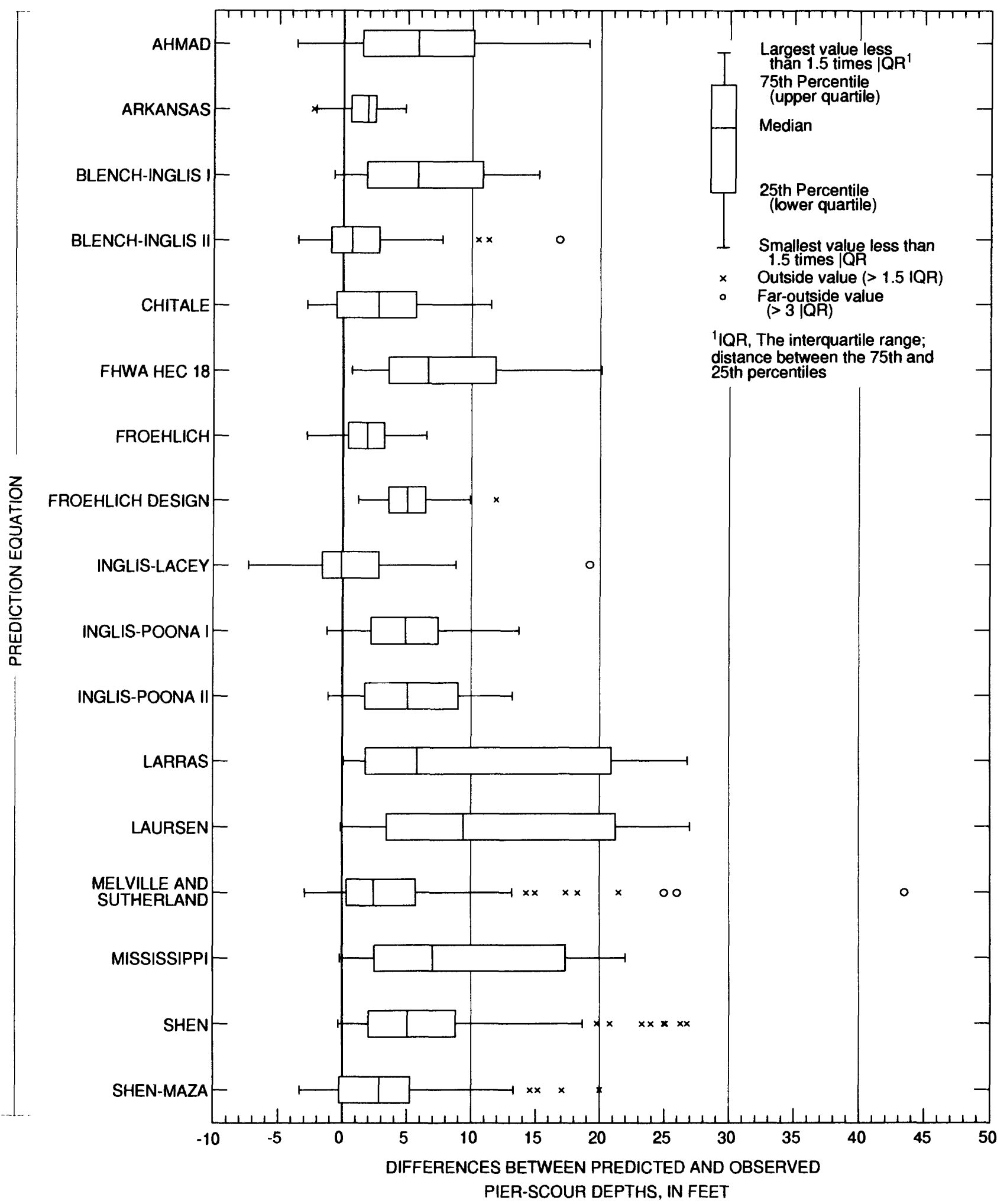

Figure 30. Distribution of residuals between predicted and observed pier-scour depths at bridge-scour study sites in Ohio. (Resuts for the Arkansas equation are based on 66 cases.) 


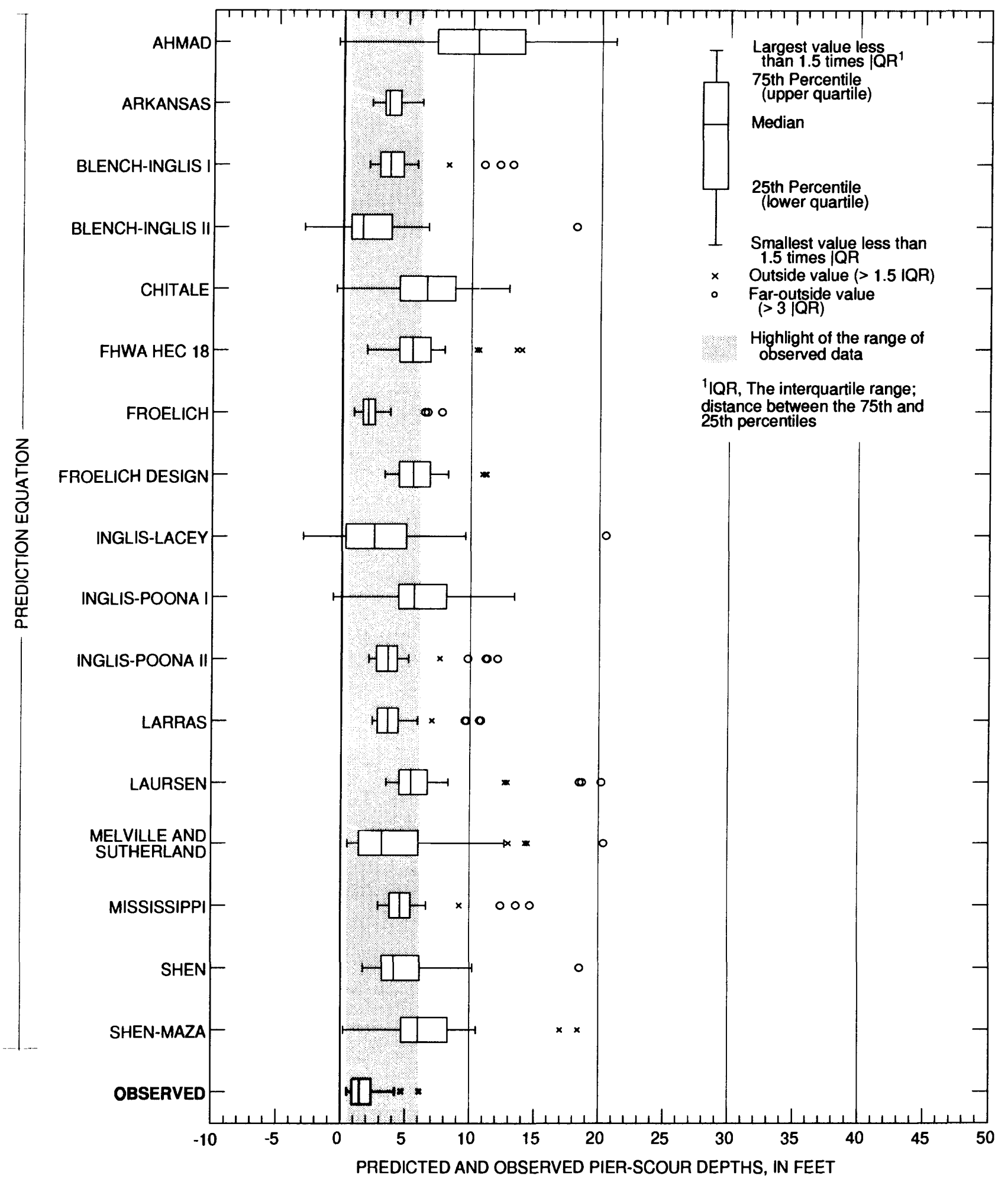

Flgure 31. Distribution of predicted and observed pier-scour depths with approach-flow attack angles of 10 degrees or less at bridge-scour study sites in Ohio. (Results for the Arkansas equation are based on 40 cases.) 


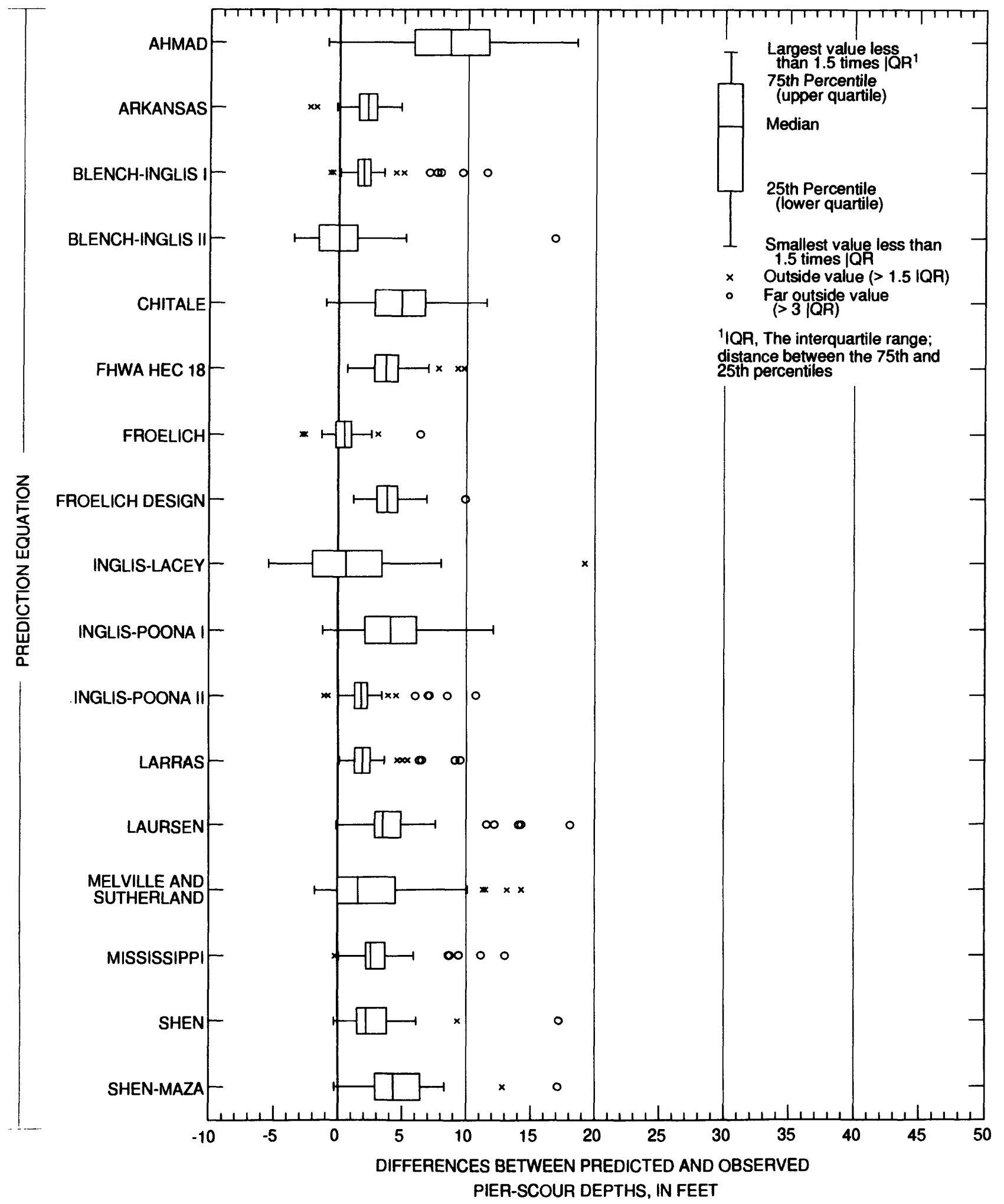

Figure 32. Distribution of residuals between predicted and observed pier-scour depths with approach-flow attack angles of 10 degrees or less at bridge-scour study sites in Ohio. (Results for the Arkansas equation are based on 40 cases.) 


\section{Evaluation of Pier-Scour Prediction Equations}

As stated previously, an ideal design pier-scour equation should accurately predict maximum scour depth and, when in error, should tend towards overestimation of scour depth. The evaluations of the pier-scour equations made in this section by use of boxplots are based on the following criteria: (1) no underpredictions, (2) median residual closest to zero, (3) small interquartile range, and (4) few large overpredictions. The equation best meeting these criteria will be considered the "best design equation." Two evaluations are presented in this section. In the first evaluation, all cases of observed pier scour are used as input data for the pier-scour equations. In the second evaluation, the input data are restricted to cases in which approach-flow attack angles were 10 degrees or less.

\section{Evaluation Using All Cases of Observed Scour}

The only three equations that did not underpredict scour depth for all 84 cases of the measured input data are the FHWA HEC 18, Froehlich Design, and Larras equations (fig. 30). The median residual represents the central tendency of the equations's error in predicting pier-scour depth. In terms of median residual values, the results of the three equations that did not underpredict pier-scour depth for all 84 cases of observed pier scour can be ranked as follows: Froehlich Design $(5.0 \mathrm{ft})<$ Larras $(5.8 \mathrm{ft})$ $<$ FHWA HEC 18 (6.6 ft). The range, from the lowest to the highest, of the magnitude of the three median residual values is $1.6 \mathrm{ft}$; hence, the central tendency of these three equations error in prediction is not substantially different.

The interquartile range provides an indication of the variability of residual data. The three equations that did not underpredict scour depth can be ranked in terms of the magnitude of the interquartile range as follows: Froehlich Design $(2.9 \mathrm{ft})<$ FHWA HEC $18(8.4 \mathrm{ft})<$ Larras $(19.7 \mathrm{ft})$. The magnitude of the interquartile ranges indicates that results of the Larras equation exhibit the most variability, more than twice that of the FHWA HEC 18 and nearly seven times that of the Froehlich Design equation.

Therefore, on the basis of the previously described criteria, the Froehlich Design was found to be the best design equation of the selected 17 pier-scour design equations for the 84 cases of the observed data. By not underestimating scour depth, this equation would provide for conservative designs. The Froehlich Design equation, however, did overpredict scour depth on the order of $10 \mathrm{ft}$ for the extreme case, and this tendency could result in an overly conservative design.

\section{Evaluation Using Cases of Observed Scour with Approach-Flow Attack Angles of 10 Degrees or Less}

For approach-flow attack angles of 10 degrees or less, the FHWA HEC 18, Froehlich-Design, and Larras equations again were the only three equations not to underpredict scour depth for the measured input data (fig. 32). In terms of median residual values, the results from these three equations can be ranked as follows: Larras $(1.9 \mathrm{ft})<$ FHWA HEC $18(3.7 \mathrm{ft})<$ Froehlich Design $(3.8 \mathrm{ft})$. The range, from the lowest to the highest, of the magnitude of the three median-residual values is $1.9 \mathrm{ft}$; hence, the central tendency of the error in prediction for these three equations is similar.

The equations ranked in terms of the magnitude of the interquartile range are as follows: Larras $(1.3 \mathrm{ft})<$ Froehlich Design $(1.7 \mathrm{ft})<$ FHWA HEC $18(1.9 \mathrm{ft})$. The magnitude of the interquartile ranges indicates that the results of the Larras equation are the least variable of the three equations.

On the basis of the previously described criteria, the Larras equation was found to be the best design equation of the selected 17 pier-scour prediction equations for the 45 cases of the observed data where approach-flow attack angles were 10 degrees or less. By not underestimating scour depth, the Larras equation would provide for conservative designs. It did overpredict, however, on the order of $9.5 \mathrm{ft}$ for the extreme case, and this tendency could result in an overly conservative design. 
Data to develop pier-scour prediction equations have been collected using various methods. Analytical techniques used to obtain prediction equations also have been varied. A brief discussion is presented detailing the types of data collected and the basic factors associated with the three equations found not to underpredict scour depth.

The equation published in Federal Highway Administration Hydraulic Engineering Circular 18 (FHWA HEC 18) (Richardson and others, 1993) was developed from laboratory data compiled for scour at circular piers. The equation predicts maximum scour depth. This equation is a function of pier width, alignment, and shape; flow velocity and depth; and bedform conditions. Recently, the FHWA HEC 18 equation was modified to account for a reduction in scour by armoring of the streambed (Richardson and others, 1995). In this investigation, estimates of pier-scour depth were generated with the FHWA HEC 18 equation prior to the modification; however, analysis of the collected data indicated that none of the estimates of pier-scour depth would be altered by the new modification. Therefore, all the results of analyses involving the FHWA HEC 18 equation would remain unchanged.

The Froehlich Design equation (Froehlich, 1988) is based on live-bed scour data at bridge piers compiled from several investigations, and these data were assumed to represent scour at equilibrium sediment transport conditions. The equation was developed using linear regression analysis of the compiled data. The predicted scour depth is supplemented with a factor of safety of the width of the pier. The equation is a function of pier width, alignment, and shape; flow velocity and depth; and median grain size.

The Larras equation (Larras, 1963) was developed using data from field investigations of rivers in France and scale-model investigations. The equation is a function of pier width and shape. Larras' field measurements were point measurements of scour depth obtained after the flood had passed and therefore, may not represent equilibrium scour depths (Shen and others, 1969).

\section{Observed Contraction Scour at Bridge Openings}

Contraction scour was evident in 4 of the 47 scour measurements. Contraction-scour depths ranged from 0.8 to $2.3 \mathrm{ft}$ (table 4). Three of the four measurements where contraction scour was observed were classified as occurring under live-bed scour conditions and the remaining one as a clear-water scour measurement.

The channel-contraction ratio $m$ (an indication of the degree of contraction imposed by the constriction of the stream channel) was obtained from the WSPRO output for each of the four scour measurements where contraction scour was evident. The channel-contraction ratio $m$ (Matthai, 1968) is defined as

$$
m=1-k_{q} / k_{a}
$$

where

$k_{q}$ is conveyance of the subsection of the approach section of the discharge that can pass through the bridge opening without contraction and

$k_{a}$ is total conveyance of the of the approach section.

Matthai states, "The channel-contraction ratio is a measure of the proportion of the total flow that enters the contraction from the sides of the channel." The channel-contraction ratios for the four measurements in which contraction scour is evident ranged from 0 to 0.01 ; thus, the measured flows were only slightly contracted, if at all. This result was not unexpected, because one of the goals of the site-selection process was to identify sites where flows would not be highly contracted to help isolate the effects of pier scour. With channel-contraction ratios at or near zero, contraction scour, as defined 
in this study, was still found in four measurements. Presumably other factors, such as the previously discussed differences in the bed-material particle size distribution between the approach and bridge opening (the median $d_{50}$ of the approach-area bed-material samples was found to be larger than the median $d_{50}$ of the bridge-area and pier-area samples), could account for some of the apparent contraction scour despite little or no contraction.

The stability of the approach sections was assessed to validate the contraction-scour analysis in this study. The difference in the postflood and preflood annual mean streambed elevations of the approach section was computed for each measurement where contraction scour was observed (table 4). This difference provided an indication of the potential error of the reference-surface elevation used to compute contraction-scour depth. The data indicate that for most scour measurements in which contraction scour is evident, the change in the approach-section mean streambed elevation was typically less than $\pm 0.5 \mathrm{ft}$.

\section{Analysis of Approach-Section Channel Stability}

To assess the stability of the approach streambed channel, the mean, standard deviation, and median of the annual mean streambed elevations for the approach sections were computed using all of the annual mean streambed elevation data for each of the scour-measurement sites. These statistics, along with the total number of annual surveys obtained at each site, are listed in table 5. For most sites, 5 or 6 years of data are represented, but 3 or fewer years of data are available for four sites. Two sites, State Route 4 over Scioto River near Prospect and Walnut Road over Tuscarawas River at Massillon, were discontinued because of bridge replacement and renovation, respectively. The sites at U.S. Route 68 over Massies Creek at Oldtown and State Route 16 over Wakatomika Creek near Frazeysburg were added as measurement sites in 1992 to replace the discontinued sites.

The standard deviation of the annual mean streambed elevation provides a measure of the longterm vertical stability of the streambed. Most of the approach sections were fairly stable (standard deviation $<0.5 \mathrm{ft}$ ) during the period of data collection. Only three of the sites showed appreciable approachsection streambed instability (standard deviation $\geq 0.5 \mathrm{ft}$ ). These three sites, State Route 84 over Grand River near Painesville (site 3), State Route 278 over Hocking River at Nelsonville (site 6), and State Route 16 over Wakatomika Creek near Frazeysburg (site 21) had standard deviations of 0.5, 0.8, and $0.6 \mathrm{ft}$, respectively.

Time-series plots of the annual mean streambed elevation data are shown for each of the 22 sites in figures 33 through 37 . Also shown on these plots is the mean of the annual mean streambed elevation computed for each site. None of the plots show a monotonic unidirectional trend in mean streambed elevation.

\section{Analysis of Geophysical Data}

Twenty scour sites were investigated by use of ground-penetrating radar (GPR) in 1990. On the basis of an evaluation of the 1990 results, six sites were revisited in 1994. These surveys were done at the sites to investigate the possibility of historical scour. Of the 20 sites investigated in 1990, records from 5 surveys showed GPR signal penetration of the streambed subsurface and indicated possible historical scour surfaces, buried debris, or rock; 9 showed penetration of the subsurface but no evidence of historical scour; and 6 showed no penetration of the subsurface. The data collected at the 6 sites revisited in 1994 did not provide any additional evidence that would alter the conclusions with respect to the presence of historical scour obtained from the 1990 surveys. 
Table 4. Data for Ohio bridge-scour study sites where contraction scour was observed

[Change in approach-section mean bed elevation is the difference between approach-section mean bed elevations obtained during annual surveys before and after the scour measurement]

\begin{tabular}{llccccc}
\hline Measurement site & $\begin{array}{c}\text { Date of } \\
\text { measure } \\
\text {-ment }\end{array}$ & $\begin{array}{c}\text { Contrac- } \\
\text { tion scour } \\
\text { depth } \\
\text { (feet) }\end{array}$ & $\begin{array}{c}\text { Sediment- } \\
\text { transport } \\
\text { condition }\end{array}$ & $\begin{array}{c}\text { Change in } \\
\text { approach- } \\
\text { section } \\
\text { mean bed } \\
\text { elevation } \\
\text { (feet) }\end{array}$ & $\begin{array}{c}\text { Channel } \\
\text { contrac- } \\
\text { tion } \\
\text { ratio }\end{array}$ \\
\hline $2 \quad \begin{array}{l}\text { U.S. Route 33 over Clear Creek } \\
\text { near Rockbridge, Ohio }\end{array}$ & $1 / 28 / 94$ & 1.5 & Clear water & 0.4 & 0.01 \\
$4 \quad \begin{array}{l}\text { State Route 128 over Great } \\
\text { Miami River at Hamilton, Ohio }\end{array}$ & $7 / 18 / 92$ & 2.3 & Live bed & .0 & 0 \\
$18 \quad \begin{array}{l}\text { State Route 22 over Todd Fork } \\
\text { at Morrow, Ohio }\end{array}$ & $5 / 17 / 90$ & .8 & Live bed & .0 & 0 \\
$18 \quad \begin{array}{l}\text { State Route 22 over Todd Fork } \\
\text { at Morrtow, Ohio }\end{array}$ & $12 / 18 / 90$ & .9 & Live bed & -.2 & 0 \\
\hline
\end{tabular}

The lack of GPR signal penetration was probably due to the physical conditions at the sites. The specific conductance and depth of water severely limited depth of penetration and usefulness of GPR at several sites. Ground-penetrating radar responds to changes in electrical properties in the subsurface; if a scour hole were present but filled with similar material as the underlying substrate, no reflection would result. Reflections and diffractions from buried debris or rocks were also used as indirect evidence that might indicate possible historical scour surfaces.

A summary of the GPR data collected at 20 scour sites in 1990, including water depth and specific conductance, is given in table 6 . At four of the five sites with evidence of possible historical scour, differences between the estimated depth of historical scour and the maximum observed scour were within $\pm 1 \mathrm{ft}$. The greatest difference between the estimated depth of historical scour and the maximum observed scour was at U.S. Route 50 over Salt Creek near Londonderry (site 14). The depth of historical scour was $3 \mathrm{ft}$ greater than the maximum scour measured at the site. The bed material at this site is predominantly very fine to very coarse sand, and the bridge has been in place since 1933. With this type of bed material and the considerable time the bridge has been in place, it would not be unreasonable for the depth of the historical scour to be greater than the maximum observed scour.

A cross section, surveyed in 1994, at the site on U.S. Route 50 over Salt Creek near Londonderry is shown in figure 38 . The section, surveyed about $0.5 \mathrm{ft}$ upstream from the upstream side of the bridge, contains many horizontal and subhorizontal reflectors, as well as hyperbolic reflectors as a result of the bridge-pier footers. A significant reflector is present from a few feet right of the left pier (pier 1) to just left of the right pier (pier 2). This reflector indicates a subsurface interface at a depth of about $5.5 \mathrm{ft}$, just left of the pier 2. The reflector is continuous and generally mimics the existing stream bottom. For several feet on either side of the pier 1 , a horizontal reflector can be seen at a depth approximately $4.5 \mathrm{ft}$ below the stream bottom. This likely corresponds to the bottom of a sand bar seen during collection of the radar data. Another strong subbottom reflection, probably reflecting stratigraphy, can be seen at a depth of about $16 \mathrm{ft}$, beneath pier 1 . 
Table 5. Summary of annual mean streambed elevation data for approach sections at bridge-scour study sites in Ohio

\begin{tabular}{|c|c|c|c|c|c|}
\hline \multirow[b]{2}{*}{ - } & \multirow{2}{*}{ Scour measurement site } & \multirow{2}{*}{$\begin{array}{l}\text { Number of } \\
\text { annual } \\
\text { surveys of } \\
\text { approach } \\
\text { sectlon }\end{array}$} & \multicolumn{3}{|c|}{$\begin{array}{c}\text { Summary statistics for annuai mean } \\
\text { streambed elevations at approach } \\
\text { section }\end{array}$} \\
\hline & & & $\begin{array}{l}\text { Mean } \\
\text { (feet above } \\
\text { sea level) }\end{array}$ & $\begin{array}{l}\text { Standard } \\
\text { deviation } \\
\text { (feet) }\end{array}$ & $\begin{array}{l}\text { Median } \\
\text { (feet above } \\
\text { sea level) }\end{array}$ \\
\hline 1 & State Route 198 over Auglaize R. nr Wapakoneta & 5 & 806.8 & 0.1 & 806.8 \\
\hline 2 & U.S. Route 33 over Clear Creek nr Rockbridge & 5 & 747.5 & .2 & 747.5 \\
\hline 3 & State Route 84 over Grand River nr Painesville & 5 & 599.4 & .5 & 599.5 \\
\hline 4 & State Route 128 over Great Miami R. at Hamilton & 6 & 555.7 & .1 & 555.8 \\
\hline 5 & State Route 41 over Great Miami River at Troy & 6 & 809.6 & .1 & 809.6 \\
\hline 6 & $\begin{array}{l}\text { State Route } 278 \text { over Hocking River at } \\
\text { Nelsonville }\end{array}$ & 5 & 659.5 & .8 & 659.9 \\
\hline 7 & State Route 67 over Honey Creek at Melmore & 6 & 817.7 & .1 & 817.7 \\
\hline 8 & County Road 621 over Killbuck Creek at Killbuck & 6 & 793.3 & .4 & 793.4 \\
\hline 9 & State Route 350 over Little Miami R. at Ft. Ancient & 6 & 653.8 & .2 & 653.8 \\
\hline 10 & U.S. Route 36 over Mad River nr Urbana & 6 & 987.0 & .1 & 987.0 \\
\hline 11 & U.S. Route 68 over Massies Creek at Oldtown & 3 & 814.3 & .4 & 814.5 \\
\hline 12 & U.S. Route 127 over Maumee River nr Sherwood & 5 & 670.9 & .0 & 670.9 \\
\hline 13 & Township Road 122 over Ottawa River at Lima & 6 & 822.3 & .1 & 822.4 \\
\hline 14 & U.S. Route 50 over Salt Creek nr Londonderry & 6 & 583.5 & .4 & 583.7 \\
\hline 15 & State Route 159 over Scioto River at Chillicothe & 5 & 593.4 & .2 & 593.5 \\
\hline 16 & State Route 4 over Scioto River nr Prospect & 3 & 891.7 & .1 & 891.7 \\
\hline 17 & State Route 250 over Sugar Creek at Strasburg & 5 & 895.5 & .2 & 895.7 \\
\hline 18 & State Route 22 over Todd Fork at Morrow & 6 & 629.7 & .1 & 629.7 \\
\hline 19 & Walnut Road over Tuscarawas River at Massillon & 2 & 917.8 & .2 & 917.8 \\
\hline 20 & $\begin{array}{l}\text { County Road } 14 \text { over Tuscarawas River at Port } \\
\text { Washington }\end{array}$ & 5 & 797.1 & .1 & 797.3 \\
\hline 21 & $\begin{array}{l}\text { State Route } 16 \text { over Wakatomika Creek nr } \\
\text { Frazeysburg }\end{array}$ & 3 & 736.0 & .6 & 735.7 \\
\hline 22 & County Road 17 over Walnut Creek nr Ashville & 5 & 693.4 & .3 & 693.3 \\
\hline
\end{tabular}



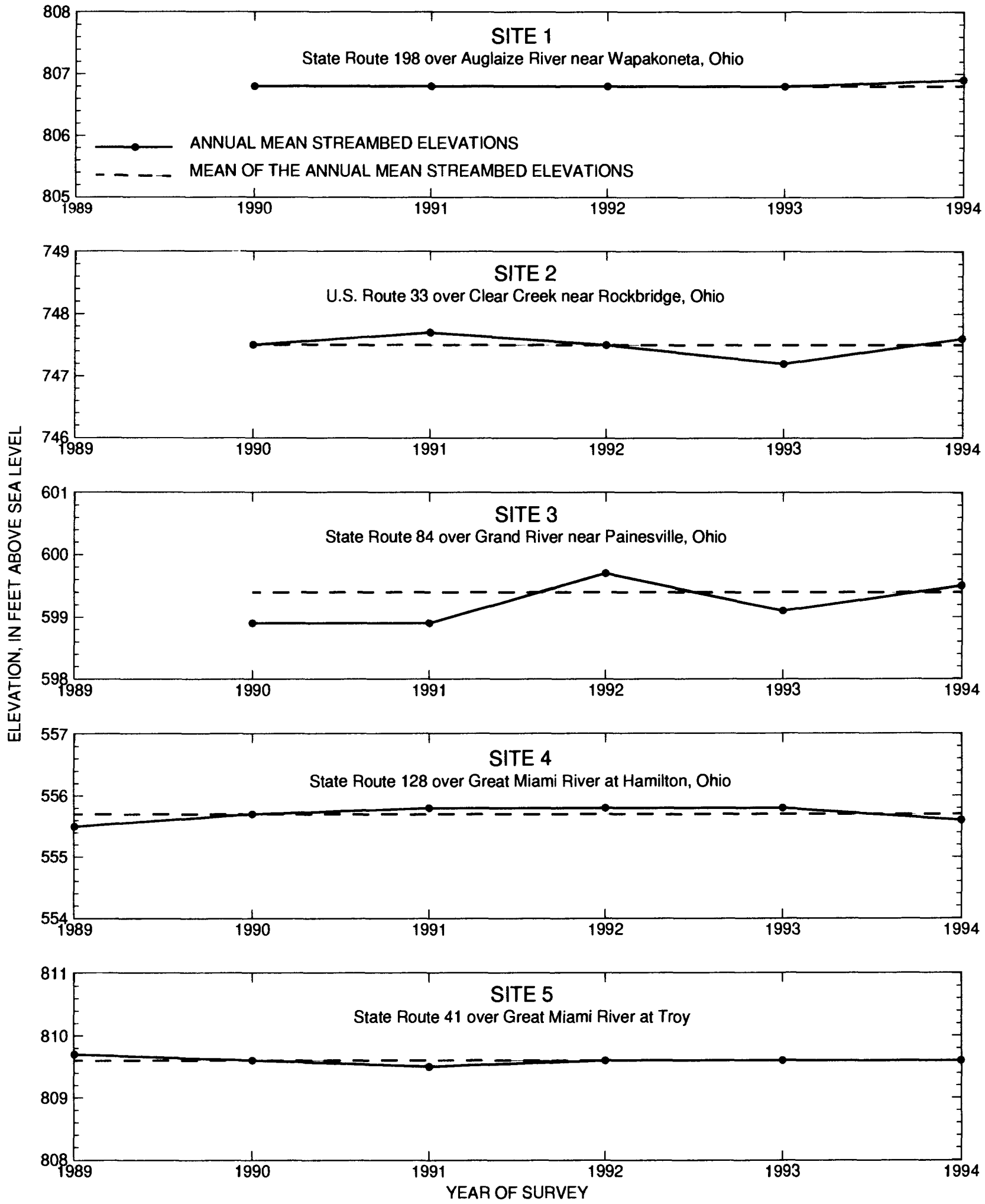

Figure 33. Annual mean streambed elevations and the mean of the annual mean streambed elevations of the approach cross sections obtained during annual low-flow surveys, sites 1 through 5, Ohio bridge-scour study. 

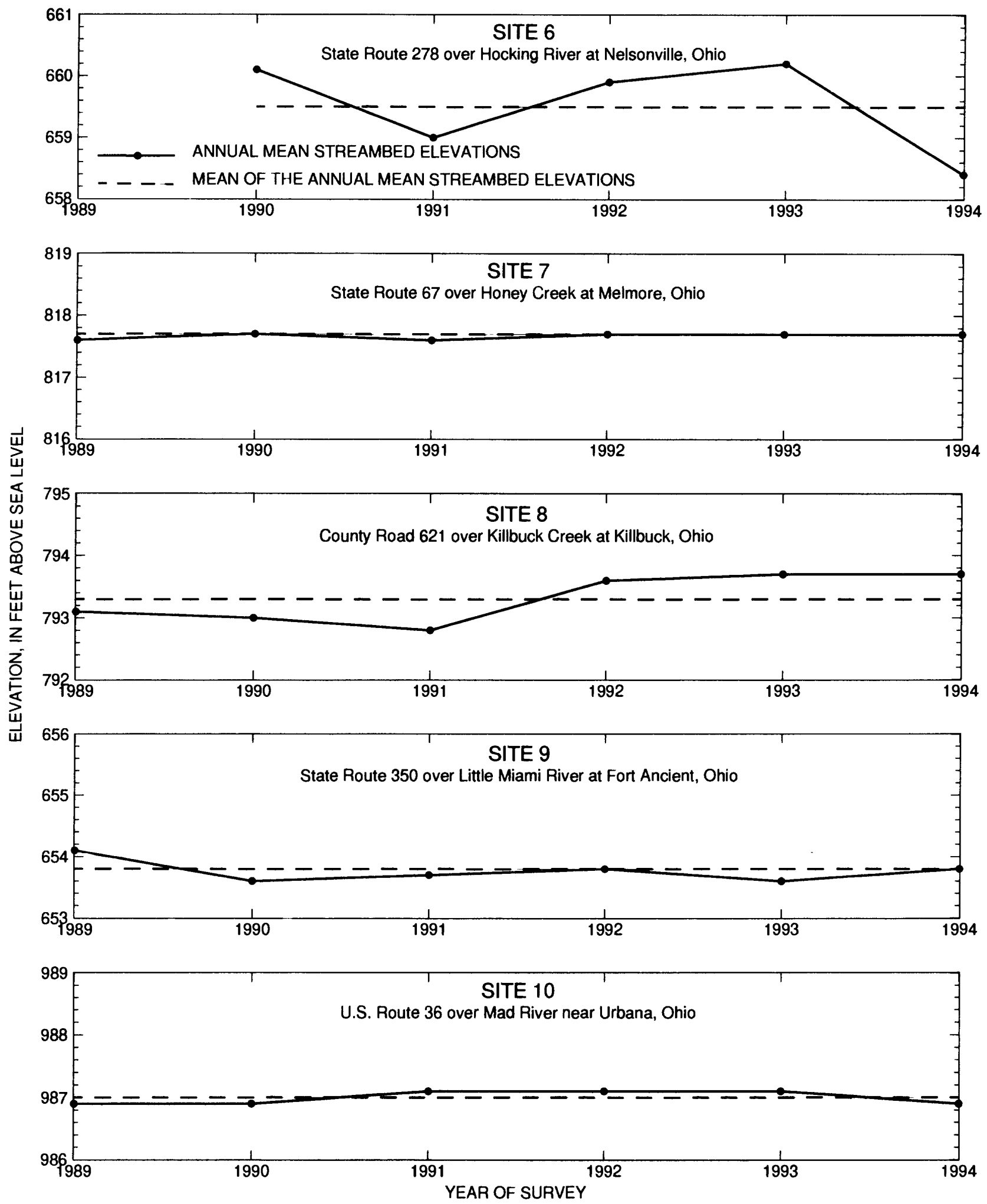

Figure 34. Annual mean streambed elevations and the mean of the annual mean streambed elevations of the approach cross sections obtained during annual low-flow surveys, sites 6 through 10, Ohio bridge-scour study. 



Figure 35. Annual mean streambed elevations and the mean of the annual mean streambed elevations of the approach cross sections obtained during annual low-flow surveys, sites 11 through 15, Ohio bridge-scour study. 

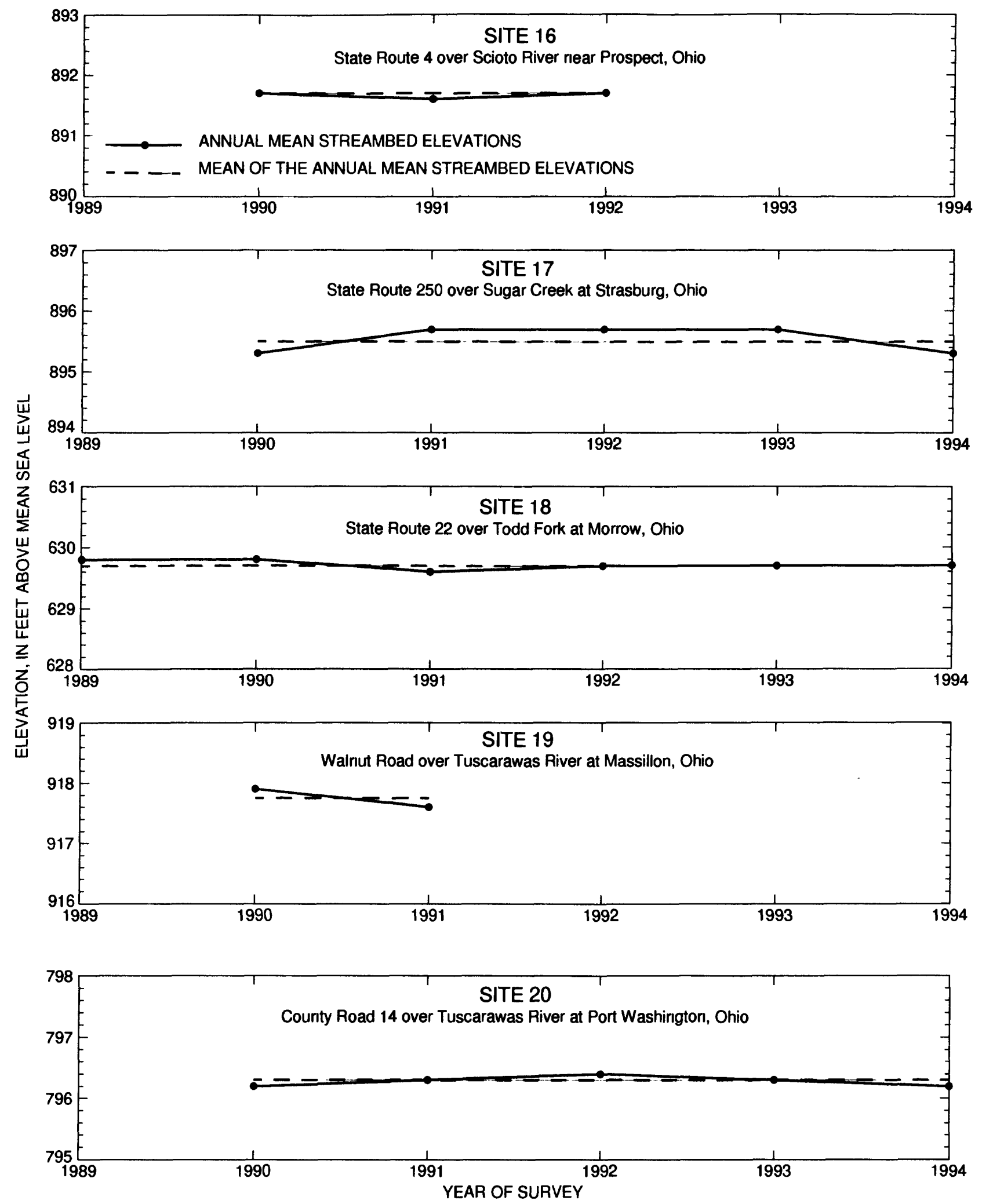

Figure 36. Annual mean streambed elevations and the mean of the annual mean streambed elevations of the approach cross sections obtained during annual low-flow surveys, sites 16 through 20, Ohio bridge-scour study. 


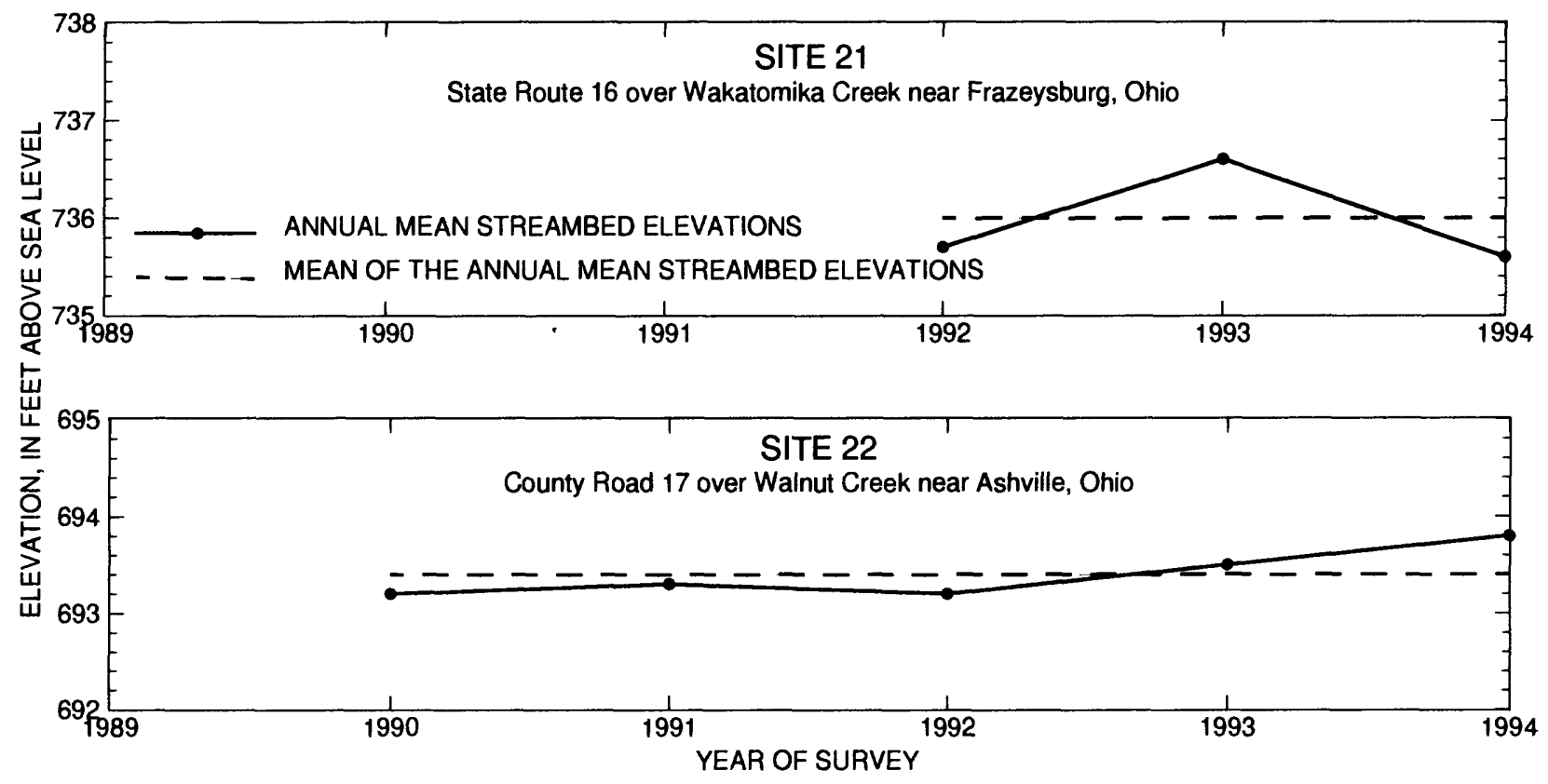

Figure 37. Annual mean streambed elevations and the mean of the annual mean streambed elevations of the approach cross sections obtained during annual low-flow surveys, sites 21 and 22, Ohio bridge-scour study. 
Table 6. Summary of 1990 ground-penetrating-radar surveys at bridge-scour study sites in Ohio [Abbreviations: $\mathrm{ft}$, feet; $\mu \mathrm{S} / \mathrm{cm}$, microsiemens per centimeter at 25 degrees Celsius; NP, no penetration of the streambed subsurface; nd, no data collected]

\begin{tabular}{|c|c|c|c|c|}
\hline \multicolumn{2}{|r|}{ Scour measurement site } & \multirow{2}{*}{$\begin{array}{l}\text { Evidence } \\
\text { of } \\
\text { historical } \\
\text { scour }\end{array}$} & \multirow{2}{*}{$\begin{array}{c}\text { Range } \\
\text { of water } \\
\text { depth } \\
\text { (ft) }\end{array}$} & \multirow{2}{*}{$\begin{array}{c}\text { Specific } \\
\text { conduct- } \\
\text { ance } \\
(\mu \mathrm{S} / \mathrm{cm})\end{array}$} \\
\hline Number & Location & & & \\
\hline 1 & State Route 198 over Auglaize R. nr Wapakoneta & YES & $2-3$ & 670 \\
\hline 2 & U.S. Route 33 over Clear Creek nr Rockbridge & NO & $0-3$ & 420 \\
\hline 3 & State Route 84 over Grand River nr Painesville & NP & $0-5$ & 200 \\
\hline 4 & State Route 128 over Great Miami R. at Hamilton & NP & $2-10$ & 750 \\
\hline 5 & State Route 41 over Great Miami River at Troy & NO & $2-3$ & 670 \\
\hline 6 & State Route 278 over Hocking River at Nelsonville & NP & $1-4$ & 785 \\
\hline 7 & State Route 67 over Honey Creek at Melmore & NO & $0-3$ & 650 \\
\hline 8 & County Road 621 over Killbuck Creek at Killbuck & NO & $2-4$ & 510 \\
\hline 9 & State Route 350 over Little Miami R. at Ft. Ancient & NO & $2-5$ & 620 \\
\hline 10 & U.S. Route 36 over Mad River nr Urbana & NO & $4-6$ & nd \\
\hline 11 & U.S. Route 68 over Massies Creek at Oldtown & nd & nd & nd \\
\hline 12 & U.S. Route 127 over Maumee River nr Sherwood & YES & $2-5$ & 570 \\
\hline 13 & Township Road 122 over Ottawa River at Lima & NO & $1-4$ & 1150 \\
\hline 14 & U.S. Route 50 over Salt Creek nr Londonderry & YES & $1-7$ & 410 \\
\hline 15 & State Route 159 over Scioto River at Chillicothe & NP & $1-11$ & 670 \\
\hline 16 & State Route 4 over Scioto River nr Prospect & NP & $3-5$ & nd \\
\hline 17 & State Route 250 over Sugar Creek at Strasburg & YES & $2-4$ & 610 \\
\hline 18 & State Route 22 over Todd Fork at Morrow & YES & $0-3$ & 631 \\
\hline 19 & Walnut Road over Tuscarawas River at Massillon & NO & $2-5$ & 560 \\
\hline 20 & County Road 14 over Tuscarawas R. at Port Washington & NP & $5-10$ & 550 \\
\hline 21 & State Route 16 over Wakatomika Creek nr Frazeysburg & nd & nd & nd \\
\hline 22 & County Road 17 over Walnut Creek nr Ashville & NO & $1-3$ & 787 \\
\hline
\end{tabular}




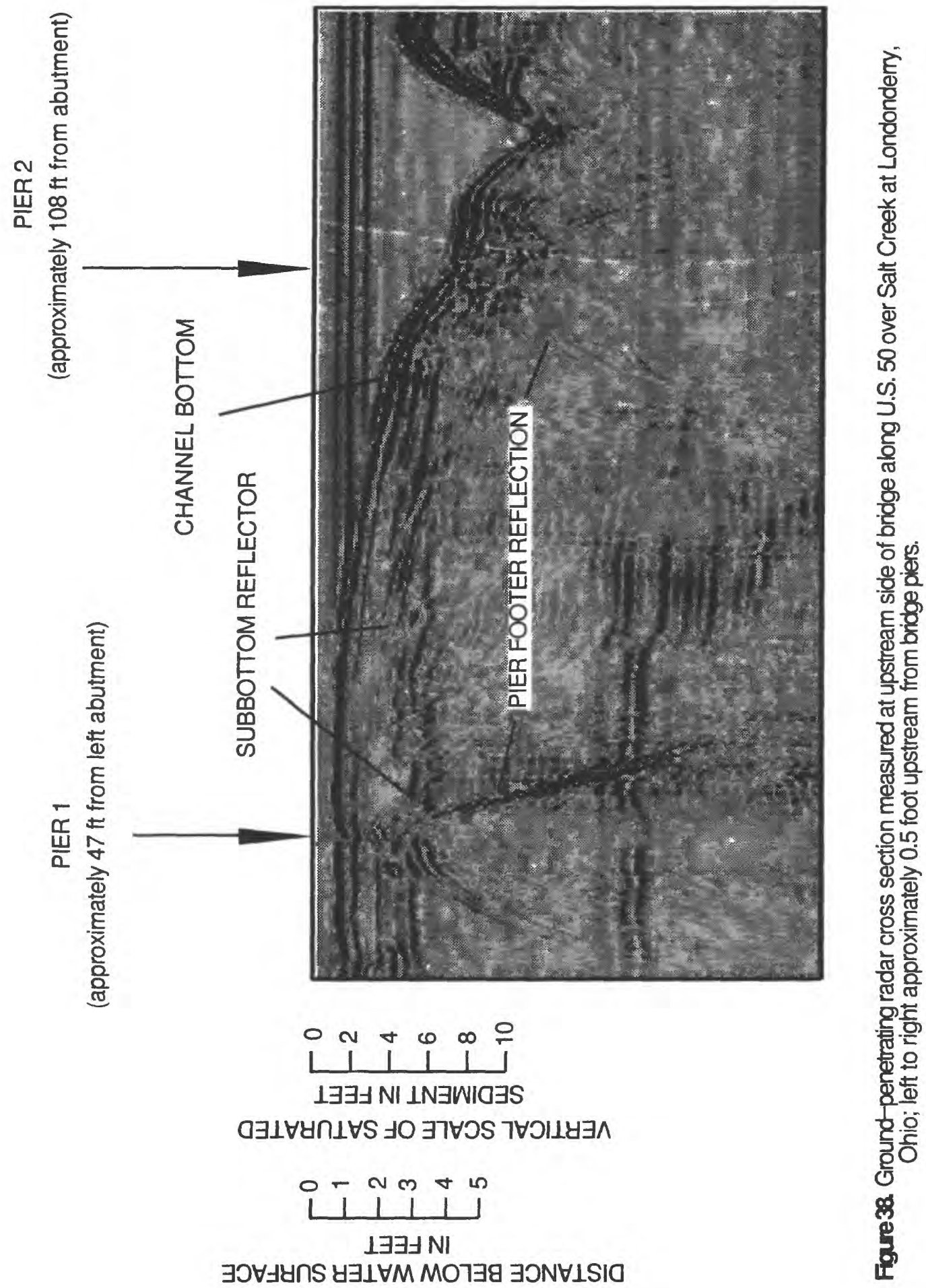




\section{SUMMARY}

Field measurements of scour at 21 selected bridge sites in Ohio were made during 1989-94. The drainage areas of the sites ranged from 84.4 to $3,849 \mathrm{mi}^{2}$. Sufficient data for a detailed analysis of scour were collected during 47 of 62 real-time scour measurements. Pier scour was observed in 45 of the 47 measurements, and contraction scour was evident in 4 of the measurements. The estimated recurrence interval for 27 of 35 corresponding streamflow measurements on unregulated streams was less than 2 years. Only 1 of the 35 measured streamflows was greater than the estimated 50-year flood.

Seventeen selected pier-scour prediction equations were evaluated on the basis of selected comparative criteria for observed and predicted values. In the first evaluation, all 84 cases of observed pier scour were used as input data for the pier-scour equations. The Froehlich Design equation was found to be the best design equation of the 17 pier-scour prediction equations for the 84 cases of the observed data. In the second evaluation, 45 cases of observed pier scour with approach-flow attack angles of 10 degrees or less were used as input data for the pier-scour equations. The Larras equation was found to be the best design equation of the selected 17 pier-scour prediction equations for these 45 cases.

Pier scour was observed at 83 solid-wall piers and 1 capped-pile-type pier. Pier-scour depths ranged from 0.5 to $6.1 \mathrm{ft}$. Of the 84 cases of observed pier scour, 55 were classified as occurring under clear-water conditions and 29 were classified as occurring under live-bed conditions. Pier-scour depth was found to increase with pier width. However, pier-scour depth never exceeded the limiting value of 2.4 times the pier width suggested by Melville and Sutherland (1988). Of the 84 cases of measured pier scour, 11 had pier-scour depth to pier-width ratios larger than 1 . The largest observed pier-scour depth to pier-width ratios for clear-water and live-bed scour were 1.7 and 1.4, respectively. For 46 percent (39 of 84) of the pier scour-measurements, approach-flow attack angles exceeded 10 degrees.

Measured flow depths ranged from 3.0 to $19.8 \mathrm{ft}$. Pier-scour depth was found to increase monotonically with flow depth to a depth of about $8 \mathrm{ft}$. At flow depths greater than $8 \mathrm{ft}$, pier-scour depth appears to decrease and then increase again but with a smaller average rate of change than indicated for flow depths less than $8 \mathrm{ft}$. Normalized scour depth was found to increase monotonically with normalized flow depth; however, the rate of increase appeared to lessen as normalized flow depth exceeded 2.5. This trend is in approximate agreement with results obtained by Melville and Sutherland (1988), who found that scour depth increases up to a limiting value of about 3 for normalized flow depth.

Normalized scour depths increased appreciably as flow intensity approached the threshold value of 1 . Normalized scour depths appear to decrease abruptly as flow intensities exceed this threshold. Froude numbers for the 84 measurements of pier-scour depth were less than 0.5 , well within the subcritical range. Normalized scour depth was found to increase with Froude number; for values of Froude number exceeding 0.2 , a steeper slope was evident. Two pier-scour prediction equations, the FHWA HEC 18 (Richardson and others, 1993) and the Froehlich (1988) equation, include a Froude number term. Both terms provided approximate upper envelopes for the range of data measured in Ohio.

Bed-material samples were collected at piers (268 samples), bridge sections ( 98 samples), and approach sections (51 samples) to assess sediment grain-size characteristics. The range of data for median grain-size diameter $\left(d_{50}\right)$ is 0.008 to $60 \mathrm{~mm}$ for pier-area samples, 0.088 to $46 \mathrm{~mm}$ for bridgearea samples, and 0.092 to $48 \mathrm{~mm}$ for approach-area samples. The median $d_{50}$ values of the three sets of bed-material samples were tested for statistical difference. No significant difference between the median $d_{50}$ values of the bridge- and pier-area samples was found. A significant difference was found between the median $d_{50}$ value of the approach-area samples and the median $d_{50}$ values of the bridgeand pier-area samples.

Normalized scour depth tended to increase with the median grain size of pier-area bed-material samples up to about $10 \mathrm{~mm}$ and then decrease as median grain size increased further. The initial 
increase conflicts with previous research, in which normalized scour depth was found to decrease as median grain size increased. Cohesion may have some influence on the relation found in the Ohio field data but is unlikely to fully explain the trend.

Melville and Sutherland's sediment-size factor, $K_{d}$, and the Froehlich equation's relative sediment size term, $\left(b / d_{50}\right)^{0.08}$, provide approximate upper envelopes for the relation of pier-scour depth normalized by effective pier width $\left(y_{s} / b_{e}\right)$ to the ratio of pier width to median grain size of pier-area samples $\left(b / d_{50}\right)$ collected in this investigation.

Normalized scour depth tended to decrease as sediment gradation of pier-area samples increased. The observed relation is generally consistent with previous research, which indicates that scour depth is reduced as sediment gradation increases.

LOWESS curves were developed for the 45 of 84 cases of observed pier scour where approachflow attack angles were less than or equal to 10 degrees and were visually compared to LOWESS curves developed for all 84 observations of pier scour. Appreciable differences in the trends of the two LOWESS curves were evident for three scour relations: (1) pier-scour depth to effective pier width, (2) pier-scour depth to flow depth, and (3) normalized scour depth to normalized flow depth. These differences indicate a potential influence of approach-flow attack angle upon these relations.

Contraction scour was evident in 4 of 47 of the scour measurements. Contraction-scour depths ranged from 0.8 to $2.3 \mathrm{ft}$ for the four measurements. The contraction-scour measurements were classified as one clear-water scour and three live-bed scour measurements. The channel-contraction ratios for the four measurements ranged from 0 to 0.01 , indicating that the measured streamflows were only slightly contracted, if at all.

On the basis of standard deviations of annual mean streambed elevations, approach sections at 18 of the 22 sites were fairly stable. None of the 22 sites showed evidence of a monotonic trend of mean streambed elevation.

Ground-penetrating radar surveys were made at the sites to investigate the possibility of historical scour. Of the 20 sites investigated, 5 surveys indicated possible historical scour surfaces. At four of five sites with evidence of possible historical scour, differences between the estimated depth of historical scour and the maximum observed scour were within $\pm 1 \mathrm{ft}$; for the fifth site, the depth of historical scour was $3 \mathrm{ft}$ greater than the maximum scour measured. 
Ahmad, Mushtaq, 1953, Experiments on design and behavior of spur dikes, in Minnesota International Hydraulics Convention, Minneapolis, Minnesota, 1953, Proceedings: Minneapolis, Minn., p. 145159.

Ahmad, Mushtaq, 1962, Discussion of "Scour at bridge crossings," by E.M. Laursen: Transactions of the American Society of Civil Engineers, v. 127, Part I, no. 3294, p.198-206.

Anderson, A.G., 1974, Scour at bridge waterways-A review: Federal Highway Administration Report FHWA-RD-89, 29 p.

Baker, R.E., 1986, Local scour at bridge piers in non-uniform sediment: Auckland, New Zealand, University of Auckland School of Engineering, Masters thesis, Report 402, 91 p.

Ballester, R.E., and Lacey, Gerald, 1936, Discussion of "Stable channels in erodible material," by E.W. Lane: Proceedings of the American Society of Civil Engineers, v. 62, no. 5, p. 775-779.

Blench, Thomas, 1951, Regime theory for self-formed sediment-bearing channels: Proceedings of the American Society of Civil Engineers, v. 77, separate 70, 18 p.

Blench, Thomas, 1962, Discussion of "Scour at bridge crossings," by E.M. Laursen: Transactions of the American Society of Civil Engineers, v. 127, Part I, no. 3294, p. $180-183$.

Blench, Thomas, 1969, Mobile-bed fluviology (2nd ed.): Edmonton, Alberta, Canada, University of Alberta Press, 221 p.

Breusers, H.N.C., 1964-65, Scour around drilling platforms: Bulletin, Hydraulic Research 1964 and 1965, International Association of Hydraulic Research, v. 19, p. 276.

Breusers, H.N.C., Nicollet, G., and Shen, H.W., 1977, Local scour around cylindrical piers: Journal of Hydraulic Research, v. 15, no. 3, p. 211-252.

Chee, R.K.M., 1982, Live-bed scour at bridge piers: Auckland, New Zealand, University of Auckland School of Engineering, Report 290, 79 p.

Chiew, Y.M., 1984, Local scour at bridge piers: Auckland, New Zealand, University of Auckland School of Engineering, Ph.D. thesis, Report 355, 200 p.

Chiew, Y.M., and Melville, B.W., 1987, Local scour around bridge piers: Journal of Hydraulic Research, v. 25, no. 1, p. 15-26.

Chin, C.O., 1985, Stream bed armouring: Ph.D. thesis Auckland, New Zealand, University of Auckland School of Engineering Ph.D. thesis, Report 403, 248 p.

Chitale, S.V., 1962, Discussion of "Scour at bridge crossings," by E.M. Laursen: Transactions of the American Society of Civil Engineers, v. 127, Part I, no. 3294, p. 191-196. 
Cleveland, W.S., 1979, Robust locally weighted regression and smoothing scatterplots: Journal of the American Statistical Association, v. 74, p. 829-836.

Cleveland,W.S., and McGill, R., 1984, The many faces of a scatterplot: Journal of the American Statistical Association, v. 74, p. 807-822.

Crumrine, M.D., 1991, Results of a reconnaissance bridge-scour study at selected sites in Oregon using surface-geophysical methods: U.S. Geological Survey Water-Resources Investigations Report 90-4199, 44 p.

Ettema, R., 1976, Influence of bed material gradation on local scour: Auckland, New Zealand, University of Auckland School of Engineering, Report 124, 147 p.

Ettema, R., 1980, Scour at bridge piers: Auckland, New Zealand, University of Auckland School of Engineering, Report 216, 527 p.

Froehlich, D.C., 1988, Analysis of onsite measurements of scour at piers, in Abt, S.R. and Gessler, Johnasses, eds., Hydraulic Engineering - Proceedings of the 1988 National Conference on Hydraulic Engineering: New York, American Society of Civil Engineers, p. 534-539.

Gorin, S.R., and Haeni, F.P., 1989, Use of surface-geophysical methods to assess riverbed scour at bridge piers: U.S. Geological Survey Water-Resources Investigations Report 88-4212, 33 p.

Guy, H.P., and Norman, V.W., 1970, Field methods for measurement of fluvial sediment: U.S. Geological Survey Techniques of Water-Resources Investigations, book 3, chap. C2, 59 p.

Haeni, F.P., 1992, Use of ground-penetrating radar and continuous seismic-reflection profiling on surface-water bodies in environmental and engineering studies, in Bell, R.S., ed., Symposium on the Application of Geophysics to Engineering and Environmental Problems, Oakbrook, Illinois, April 26-29, 1992, Proceedings: Golden, Colo., Society of Engineering and Mineral Exploration Geophysicists, p. 145-162.

Haeni, F.P., and Placzek, Gary, 1991, Use of processed geophysical data to improve the delineation of infilled scour holes at bridge piers, in Expanded abstracts with biographies, SEG 61st Annual International Meeting, Houston, Texas, November 10-14, 1991: Houston Texas, Society of Exploration Geophysicists, p. 549-552.

Haeni, F.P, Placzek, Gary, and Trent, R.E., 1992, Use of ground-penetrating radar to investigate infilled scour holes at bridge foundations, in Hanninen, Pauli, and Autio, Sini, eds., Fourth International Conference on Ground Penetrating Radar, Rovaniemi, Finland, June 8-13, 1992, Proceedings: Geological Survey of Finland Special Paper 16, p. 285-292.

Hopkins, G.R., Vance, R.W., and Kasraie, B., 1980, Scour around bridge piers: Federal Highway Administration Publication FHWA-RD-103, 124 p.

Inglis, C.C., 1949, The behavior and control of rivers and canals: Poona, India, Poona Research Station, Central Water Power Irrigation and Navigation Report 13, Part II. 
Jarrett, R.D., and Boyle, J.M, 1986, Pilot study for collection of bridge-scour data: U.S. Geological Survey Water-Resources Investigations Report 86-4030, 46 p.

Joglekar, D.V., 1962, Discussion of "Scour at bridge crossings," by E.M. Laursen: Transactions of the American Society of Civil Engineers, v. 127, Part I, paper 3294, p. 183-186.

Jones, J.S., Kilgore, R.T., and Mistichelli, M.P., 1992, Effects of footing location on bridge pier scour: Journal of Hydraulic Engineering, v. 118, no. 2, p. 280-290.

Koltun, G.F., and Roberts, J.W., 1990, Techniques for estimating flood-peak discharges of rural unregulated streams in Ohio: U.S. Geological Survey Water-Resources Investigations Report 89$4126,68 \mathrm{p}$.

Lagasse, J.D., Thompson, P.L., and Sabol, S.A., 1995, Guarding against scour: Civil Engineering, v. 65, no. 6, p. 56-59.

Landers, M.N., and Mueller, D.S, 1993, Reference surfaces for bridge scour depths: Proceedings of the 1993 National Conference on Hydraulic Engineering, American Society of Civil Engineers, p. 2075-2080.

Landers, M.N., Mueller, D.S, and Martin, G.R., 1996, Bridge-scour data management system user's manual: U.S. Geological Survey Water-Resources Investigations Report 95-754 [variously paged].

Larras, Jean, 1963, Profondeurs maximales d'erosion des fonds mobiles autour des piles en riviere [maximum depth of erosion in shifting bed around river piles]: Annales des Ponts et Chaussees, v. 133 , no. 4 , p. $411-424$.

Laursen, E.M., 1962, Scour at bridge crossings: Transactions of the American Society of Civil Engineers, v. 127, Part I, paper 3294, p. 166-180.

Laursen, E.M., and Toch, Arthur, 1956, Scour around bridge piers and abutments: Iowa Highway Research Board Bulletin 4, $60 \mathrm{p}$.

Matthai, H.F., 1968, Measurement of peak discharge at width contractions by indirect methods: U.S. Geological Survey Techniques of Water-Resources Investigations, book 3, chap. A4, 44 p.

Maza Alvares, J.A., and Sanchez Bribiesca, J.L., 1964, Contribucion al estudio de la socavacion local en pilas de puente: Universidade Federal do Rio Grande do Sul, August.

McIntosh, J.L., 1989, Use of scour prediction formulae, in Proceedings of the Bridge Scour Symposium: Federal Highway Administration Publication FHWA-RD-90-035, p. 78-91.

Melville, B.W., 1975, Local scour at bridge sites: Auckland, New Zealand, University of Auckland School of Engineering, Report 117, 227 p.

Melville, B.W., 1984, Live-bed scour at bridge piers: Journal of Hydraulic Engineering, v. 110, no. HY9, p. 1234-1247. 
Melville, B.W. and Sutherland, A.J., 1988, Design method for local scour at bridge piers: Journal of Hydraulic Engineering, v. 114, no. 10, p. 1210-1226.

Mueller, D.S., 1996, Local scour at bridge piers in nonuniform sediment under dynamic conditions: Fort Collins, Colo., Colorado State University, Department of Civil Engineering, Ph.D. dissertation, $212 \mathrm{p}$.

Mueller, D.S, 1993, Bridge-scour analysis using the Water-Surface Profile (WSPRO) model : Proceedings of the 1993 National Conference on Hydraulic Engineering: New York, American Society of Civil Engineers, p. 1714-1719.

Mueller, D.S., Miller, R.L., and Wilson, J.T., 1994, Historical and potential scour around bridge piers and abutments of selected stream crossings in Indiana: U.S. Geological Survey Water-Resources Investigations Report 93-4066, 109 p.

Murillo, J.A., 1987, The scourge of scour: Civil Engineering, v. 57, no. 7, p. 66-69.

Neill, C.R., 1968, Note on initial movement of coarse uniform bed material: Journal of Hydraulic Research, v. 27, p. 247-249.

Norman, V. W., 1975, Scour at selected bridge sites in Alaska: U.S. Geological Survey WaterResources Investigations 32-75, $160 \mathrm{p}$.

Placzek, Gary, Haeni, F.P., and Trent, R.E., 1993, Use of geophysical data to assess scour development, in Hydraulic Engineering '93, National Conference on Engineering Hydrology, San Francisco, July 25-30, 1993, Proceedings: American Society of Civil Engineers, p. 20512056.

Purpura, W. J., 1994, How safe is that bridge: Home and Away/ Ohio [Ohio AAA Auto Club], Nov./ Dec., p. 8A and 20A.

Rantz, S.E,. and others, 1982, Measurement and computation of streamflow. Volume 1. Measurement of stage and discharge: U.S. Geological Survey Water-Supply Paper 2175, 284 p.

Raudkivi, A.J., 1986, Functional trends of scour at bridge piers: Journal of Hydraulic Engineering, v. 112 , no. 1 , p. $1-13$.

Raudkivi, A.J., and Ettema, Robert, 1977, Effect of sediment gradation on clear water scour: Journal of the Hydraulics Division, American Society of Civil Engineers, v. 103, no. HY 10, p. 12091213.

Raudkivi, A.J. and Ettema, Robert, 1983, Clear-water scour at cylindrical piers: Journal of Hydraulic Engineering, v. 109, no. 3, p. 338-350.

Richards, N.A., 1991, Review of channel stability assessment techniques, pier scour equations, and countermeasures: Fort Collins, Colo., Colorado State University, Department of Civil Engineering, Paper submitted for fulfillment of CE695BV, 80 p. 
Richardson, E.V., and Davis, S.R., 1995, Evaluating scour at bridges (3d ed.): U.S Federal Highway Administration Hydraulic Engineering Circular 18, Publication FHWA-IP-90-017, 204 p.

Richardson, E.V., Harrison, L.J., Richardson, J.R., and Davis, S.R., 1993, Evaluating scour at bridges (2d ed.): U.S Federal Highway Administration Hydraulic Engineering Circular 18, Publication FHWA-IP-90-027 [variously paginated].

Richardson, E.V.; Simons, D.B.; Karaki, Susumu; Mahmood, Khalid; and Stevens, M.A., 1975, Highways in the river environment-Hydraulic and environmental design considerations: Federal Highway Administration, $476 \mathrm{p}$.

Shearman, J.O., 1990, User's manual for WSPRO—A computer model for water surface profile computations: Federal Highway Administration Publication FHWA-IP-89-027, 177 p.

Shearman, J.O., Kirby, W.H., Schneider, V.R., and Flippo, H.N., 1986, Bridge waterways analysis model—Research report: Federal Highway Administration Publication FHWA-RD-86-108, 112 p.

Shen, H.W., Schneider, V.R., and Karaki, Susumu, 1969, Local scour around bridge piers: Journal of the Hydraulics Division, American Society of Civil Engineers, v. 95, no. HY6, paper 6891, p. 19191940.

Southard, R.E., 1992, Scour around bridge piers on streams in Arkansas: U.S. Geological Survey Water-Resources Investigations Report 92-4126, 29 p.

Wilson, K.V., Jr., 1995, Scour at selected bridge sites in Mississippi: U.S. Geological Survey WaterResources Investigations Report 94-4241, 44 p. 
APPENDIX 


\title{
APPENDIX
}

\section{Description of pier-scour equations}

\author{
By David S. Mueller and K. Scott Jackson
}

In a literature review of bridge-scour equations, McIntosh (1989, p. 85) found that more than 35 equations have been proposed for estimating the local scour at bridge piers. Most local-scour equations are based on research with scale models in laboratory flumes with cohesionless, uniform bed material and limited field verification (McIntosh, 1989, p. 85). These equations produce a wide range of scour-depth estimates for the same set of conditions (Anderson, 1974; Hopkins and others, 1980; Richards, 1991).

Review and evaluation of all published equations were beyond the scope of this study; therefore, several equations with potential applicability to Ohio were selected. A consistent notation for variables is used for presentation and discussion of the equations in this report. Consequently, the notation used herein may not be identical to the notation in the references cited. The variables are defined in the text the first time they are introduced. A complete listing of the variables is provided in the "Symbols" section at the front of this report. Many of the equations are dimensionless; therefore, any units can be used so long as they are consistent. If an equation requires a particular set of units, the units are defined with the equation in which they are required.

Before the selected equations are discussed, it is necessary to explain how the data collected and method of analysis affect the computed depth of scour. Many papers in the literature lack a thorough explanation of whether the measured depth of scour represents equilibrium or maximum scour depth. The measured scour, particularly in the flume, is commonly taken to be the equilibrium depth of scour, which is measured after equilibrium sediment transport has occurred and which averages the periodic change in bed elevation caused by the movement of bedforms. Therefore, equations that are based on laboratory data often compute equilibrium scour. Some researchers have assumed that the scour measured in the field represents equilibrium conditions, whereas others have assumed that it represents maximum conditions. It is usually impossible to determine the extent to which the equilibrium or maximum condition is represented in a field measurement without continuous monitoring. Thus, judgement is required when interpreting field data. The method used to develop the pier-scour equations further complicates the description of which depth of scour is computed by the equations. If a regression analysis was used and no additional corrections were added, then the depth of scour computed would not be a maximum scour for all sites. If an envelope curve was drawn above the data and used to develop the equation, then the depth of scour from this equation would, by design, exceed all measured depths of scour. For design purposes, it may be desirable to use an equation that produces the maximum depth of scour that could be expected, thereby ensuring that the design achieves an acceptable factor of safety. Alternatively, an accurate predictive equation would allow a designer to assign a risk-based factor of safety to a given scour estimate. 


\section{Ahmad}

On the basis of previous work on scour around spur dikes, Ahmad (1953) concluded that local scour does not differ with grain size in the range usually found in the alluvial plains of West Pakistan ( 0.1 to $0.7 \mathrm{~mm}$ ). He admitted, however, that this conclusion may not be valid for the entire range of bed-material grain sizes. Ahmad (1962) reanalyzed the work of Laursen (1962) with special emphasis on his (Ahmad's) experience with scour in sand-bed streams in West Pakistan and developed the following equation:

where

$$
y_{p}=K q^{2 / 3}
$$

$$
y_{p}=y_{o}+y_{s},
$$

$q$ is discharge per unit width just upstream from the pier;

$y_{p}$ is depth of flow at the bridge pier, including local pier scour;

$y_{o}$ is depth of flow just upstream from the bridge pier, excluding local scour;

$y_{s}$ is depth of pier scour below the ambient bed; and

$K$ is a coefficient that is a function of boundary geometry, abutment shape, width of the piers, shape of the piers, and angle of the approach flow. On the basis of numerous model studies, Ahmad (1962) suggested that the coefficient should be in the range of 1.7 to 2.0 to calculate scour at piers and abutments. For this investigation, it was assumed to be 1.8.

( Note: Equation 5 is not dimensionless; $y_{p}$ is in feet and $q$ is in cubic feet per second per foot.)

Substituting equation 6 for $y_{p}$ in equation 5 and solving for $y_{s}$ yields

$$
y_{s}=K q^{2 / 3}-y_{o} \text {. }
$$

(Note: Equation 7 is not dimensionless; $y_{s}$ and $y_{o}$ are in feet and $q$ is in cubic feet per second per foot.)

Equation 7 is referred to herein as the "Ahmad equation."

\section{Arkansas}

Southard (1992) used field data collected at 12 sites on streams in Arkansas during 14 floods to develop a regression equation for predicting the observed scour. The recurrence intervals of the floods ranged from 3 years in the Illinois River Basin to 100 years in the Red River Basin. The data were log transformed to correct for right skewness, and multiple-linear-regression procedures were applied. Equation 8, referred to herein as the Arkansas equation, resulted from this analysis: 


$$
y_{s}=0.827\left(d_{50}\right)^{-0.117}\left(V_{o}\right)^{0.684} e^{0.476(c)},
$$

where

$d_{50}$ is the median grain size of the bed material,

$V_{o}$ is the velocity of the approach flow just upstream from the bridge pier, and

$c$ is a value of 0 assigned for piers in the main channel, or a value of 1 assigned for piers on the banks of the main channel or on the flood plain.

(Note: equation 8 is not dimensionless; $d_{50}$ is in feet, and $V_{o}$ is in feet per second.)

This equation had an average standard error of estimate of \pm 42 percent on the data base in Arkansas. Application of the Arkansas equation is limited to sites where median grain size of the bed-material is between 0.00036 and $0.0689 \mathrm{ft}$ and the approach velocity is 1.7 to

$12.8 \mathrm{ft} / \mathrm{s}$.

\section{Blench-Inglis}

Inglis (1949) did numerous experiments with model bridge piers and developed an empirical formula by fitting an equation to the plotted data. Blench (1962) reduced Inglis' (1949) original formula to the form

$$
\frac{y_{p}}{y_{r}}=1.8\left(\frac{b}{y_{r}}\right)^{0.25}
$$

where

$$
y_{r}=\left(\frac{q^{2}}{f_{b}}\right)^{1 / 3}
$$

and $\quad b$ is width of the bridge pier,

$y_{r}$ is regime depth of flow, and

$f_{b}$ is the bed factor.

Blench (1951) stated that the bed factor was related to the nature of the sediment load and defined it as

$$
f_{b}=\frac{V^{2}}{y_{o}},
$$

where $\quad V$ is average velocity of the section.

Equation 11 is not acceptable for estimating the bed factor in the design of regime channels because the velocity will have a direct effect on the width and depth of the channel. Ballester and Lacey (1936) proposed a rough estimate for the bed factor based on grain size; this relation was modified by other researchers, including Blench $(1951,1969)$. Although the value of the coefficient varies in the literature, a value of 1.9 is common, and is used herein: 


$$
f_{b}=1.9 d_{50}^{0.5} \text {. }
$$

(Note: This equation is not dimensionless; $d_{50}$ is in millimeters.)

Equations $6,9,10$, and 11 can be solved for $y_{s}$ if the average velocity and depth in equation 11 can be approximated by the conditions just upstream from the pier. Solving for $y_{s}$ and writing in terms of basic variables results in equation 13 referred to herein as the "Blench-Inglis I equation":

$$
y_{s}=1.8 b^{0.25} y_{o}^{0.75}-y_{o} \text {. }
$$

Equation 13 is independent of velocity because the velocity present in the unit discharge and the bed factor cancel.

Alternatively, equations $6,9,10$, and 12 can be solved for $y_{s}$ if the bed factor is estimated on the basis of grain size. Solving for $y_{s}$ and writing in terms of basic variables results in equation 14 referred to herein as the "Blench-Inglis II equation":

$$
y_{s}=1.53 b^{0.25} V_{o}^{0.5} y_{o}^{0.5} d_{50}^{-0.125}-y_{o},
$$

where $\quad V_{o}$ is velocity of the approach flow just upstream from the bridge pier (or abutment).

(Note: Because equation 13 was used in the derivation, equation 14 is not dimensionless; $y_{s}, b$, and $y_{o}$ are in feet, $V_{o}$ is in feet per second, and $d_{50}$ is in millimeters.)

\section{Chitale}

A series of experiments on a 1:65-scale model of the Hardings Bridge was done to determine the influence of the upstream depth and sand diameter on scour around piers. The bed of the flume contained $0.32 \mathrm{~mm}$ sand, but four different sands having mean diameters of $0.16 \mathrm{~mm}, 0.24 \mathrm{~mm}, 0.68 \mathrm{~mm}$, and $1.51 \mathrm{~mm}$ were used in the immediate vicinity of the piers. Each experiment was run until the scour depth reached equilibrium. Chitale (1962, p. 196) observed that

1. With axial flow, maximum depth of scour was always at the nose of the pier, and scour at the sides was 5 to 15 percent less than at the nose.

2. The ratio of scour at the nose and depth of flow in the channel bears a simple relation to the approach velocity in the channel.

3. The depth of flow upstream from the pier also has an influence on the scour at the pier nose.

Although some scatter of the data was evident, the Froude number provided the best criterion with which to characterize the relative depth of the scour hole, and Chitale (1962) developed the following equation: 


$$
\frac{y_{s}}{y_{o}}=-5.49 F^{2}+6.65 F-0.51 \text {, }
$$

where

$$
F=\frac{V_{o}}{\sqrt{g y_{o}}},
$$

$F$ is the Froude number of the flow just upstream from the pier, and

$g$ is the acceleration of gravity.

Solving equation 15 for $y_{s}$ results in

$$
y_{s}=y_{o}\left(-5.49 F^{2}+6.65 F-0.51\right) \text {, }
$$

which is referred to herein as the "Chitale equation."

Although one of the objectives of the model experiments was to determine the influence of sediment size on the depth of scour, the final equation does not account for sediment size. However, a visual analysis of the scatter of data around equation 15 showed that bed-material size can affect the relative depth of scour by as much as a factor of 2 for Froude numbers less than 0.2 but to a lesser extent for Froude numbers greater than 0.2 .

\section{Federal Highway Administration Hydraulic Engineering Circular 18 (FHWA HEC 18)}

By use of all of the available laboratory data for scour at circular piers, Richardson and others (1975) developed the following equation:

$$
\frac{y_{s}}{y_{o}}=2.0 K_{1} K_{2} K_{3}\left(\frac{b}{y_{o}}\right)^{0.65} F^{0.43},
$$

where $\quad K_{1}$ is a coefficient based on the shape of the pier nose (1.1 for square-nosed piers, 1.0 for circular- or round-nosed piers, 0.9 for sharp-nosed piers, and 1.0 for a group of piers),

$K_{2}$ is a coefficient based on the ratio of the pier length to pier width and the angle of the approach flow referenced to the bridge pier, and

\begin{tabular}{cccc}
\hline Angle & $L / b=4$ & $L / b=8$ & $L / b=12$ \\
\hline 0 & 1.0 & 1.0 & 1.0 \\
15 & 1.5 & 2.0 & 2.5 \\
30 & 2.0 & 2.75 & 3.5 \\
45 & 2.3 & 3.3 & 4.3 \\
90 & 2.5 & 3.9 & 5.0 \\
\hline
\end{tabular}


$K_{3}$ is a coefficient based on the bed conditions.

\begin{tabular}{lcl}
\hline Bed condition & Dune height & $K_{3}$ \\
\hline Clear-water scour & N/A & 1.1 \\
Plane bed and antidune flow & N/A & 1.1 \\
Small dunes & $2-10 \mathrm{ft}$ & 1.1 \\
Medium dunes & $10-30 \mathrm{ft}$ & $1.1-1.2$ \\
Large dunes & $>30 \mathrm{ft}$ & 1.3 \\
\hline
\end{tabular}

Solving equation 18 for $y_{s}$ yields

$$
y_{s}=2.0 y_{o} K_{1} K_{2} K_{3}\left(\frac{b}{y_{o}}\right)^{0.65} \boldsymbol{F}^{0.43},
$$

which is referred to herein as the "FHWA HEC 18 equation." Although Richardson and others (1975) originally placed no restrictions on the use of $K_{1}$, Richardson and others (1993) later stated $K_{1}$ should be set equal to 1 if the attack angle of the approach flow is greater than $5^{\circ}$ because, at these greater angles, the pier shape loses its effect.

\section{Froehlich}

Froehlich (1988) compiled a number of in situ measurements of local scour at bridge piers. All the data were collected during sustained high flows and are assumed to represent equilibrium sediment transport through the scour hole. The critical mean-velocity relation presented by Neill (1968) was used to extract only live-bed data from the data set. Linear regression analysis of these live-bed data was used to develop an equation for the maximum relative depth of scour at a bridge pier:

$$
\frac{y_{s}}{b}=0.32 \phi\left(\frac{b_{e}}{b}\right)^{0.62}\left(\frac{y_{o}}{b}\right)^{0.46} F^{0.2}\left(\frac{b}{d_{50}}\right)^{0.08},
$$

where

$\phi \quad$ is a coefficient based on the shape of the pier nose ( 1.3 for square-nosed piers, 1.0 for round-nosed piers, 0.7 for sharp-nosed piers).

Solving equation 20 for $y_{s}$ results in

$$
y_{s}=0.32 b \phi\left(\frac{b_{e}}{b}\right)^{0.62}\left(\frac{y_{o}}{b}\right)^{0.46} F^{0.2}\left(\frac{b}{d_{50}}\right)^{0.08},
$$

which is referred to herein as the "Froehlich equation." Although Raudkivi (1986) had earlier shown bedmaterial gradation to have a significant influence on the depth of scour, bed-gradation information was not generally available and consequently was not considered in the regression analysis. All the measured depths of scour were less than the depth of scour computed by equation 21 when the width of the pier was added to the result. Therefore, Froehlich $(1988$, p. 538) recommended, for design purposes, that the depth of scour computed by equation 20 be increased by the width of the pier. This modified form is referred to herein as the "Froehlich Design equation." 


\section{Inglis-Lacey}

The application of the pier-scour equation developed by Inglis (1949) was determined to be difficult because of the effect of local stream geometry on the unit discharge (Joglekar, 1962, p. 184). In addition,

it has to be remembered that the angle of repose of the bed material in the model and the prototype is the same, hence, the extent of scour in plan in the vertically distorted model is found always relatively greater than in the prototype. This in effect reduces the discharge intensity at the pier due to greater dispersion of flow and hence the depths of scour obtained in the model would be relatively less. (Joglekar, 1962, p. 184)

Data were collected for scour around bridge piers at 17 bridges in India. The discharges at these 17 sites ranged from 29,063 to $2,250,000 \mathrm{ft}^{3} / \mathrm{s}$, the mean diameter of the bed material ranged from 0.17 to $0.39 \mathrm{~mm}$, and measured scour depths ranged from 25 to $115 \mathrm{ft}$ (Richards, 1991, p. 35). On the basis of this data, the following formula was developed (Joglekar, 1962, p. 184; Lacey, 1930):

$$
y_{p}=0.946\left(\frac{Q}{f_{b}}\right)^{1 / 3},
$$

where

$$
f_{b}=1.76 d_{m}^{0.5}
$$

$Q$ is discharge, and

$d_{m}$ is the mean grain size of the bed material.

(Note: Equations 22 and 23 are not dimensionless; $y_{p}$ is in feet, $Q$ is in cubic feet per second, and $d_{m}$ is in millimeters. Equation 23 is another published variation of equation 12.)

Solving equations 5,22 , and 23 for $y_{s}$ and substituting the median grain size for the mean grain size results in

$$
y_{s}=0.946\left(\frac{Q}{1.76 d_{50}^{0.5}}\right)^{1 / 3}-y_{o} .
$$

(Note: Equation 24 is not dimensionless; $y_{s}, y_{o}$ are in feet, $Q$ is in cubic feet per second, and $d_{50}$ is in millimeters.)

Equation 24 is referred to herein as the "Inglis-Lacey equation."

Joglekar $\left(1962\right.$, p. 184) stated, "a representative $f_{b}$ value has to be used. From bore data, values of $f_{b}$ for each strata is to be worked out to ascertain that the anticipated depth is not based on the $f_{b}$ value which is higher than that appropriate at that depth." Because the total discharge and depth of flow is included but the width of the channel is not, the approach velocity is not defined. This would seem to limit the application of this formula to streams whose geometric and hydraulic features are similar to those at the sites in India. 


\section{Inglis-Poona}

Experiments were done at the Central Water and Power Research Station in Poona, India, in 1938 and 1939 to study scour around a single pier. These studies were done in a flume with sand having a mean diameter of $0.29 \mathrm{~mm}$. On the basis of these studies, Inglis (1949) presented this formula (Joglekar, 1962, p. 184):

$$
\frac{y_{p}}{b}=1.7\left(\frac{q^{2 / 3}}{b}\right)^{0.78} \text {. }
$$

Making the appropriate substitutions and solving equation 25 for $y_{s}$ results in

$$
y_{s}=1.7 b\left(\frac{q^{2 / 3}}{b}\right)^{0.78}-y_{o} .
$$

(Note: Equations 25 and 26 are not dimensionless; $y_{p}, y_{s}, y_{o}, b$ are in feet, and $q$ is in cubic feet per second per foot.)

This relation, referred to herein as the "Inglis-Poona I equation," is not dimensionally homogeneous; therefore, it is unlikely that it is universally applicable to other bridge-scour data. From this same set of experiments, Inglis (1949) developed a dimensionally homogeneous equation,

$$
\frac{y_{p}}{b}=1.73\left(\frac{y_{o}}{b}\right)^{0.78} \text {. }
$$

This, when solved for $y_{s}$, yields

$$
y_{s}=1.73 b\left(\frac{y_{o}}{b}\right)^{0.78}-y_{o} \text {, }
$$

which is referred to herein as the "Inglis-Poona II equation."

\section{Larras}

Larras (1963) defined a stable river as one that transports enough material to maintain the bed at a constant level and an unstable river as one that has inadequate sediment transport to maintain the bed at a constant level. According to Hopkins and others (1980),

Larras concluded that maximum scouring is independent of the water depth and bed material size if the bed is stable, water depth is greater than 30 to 40 times the size of the bed material, and the channel constriction is less than 10 percent at the bridge site. The scour depth is a function of the maximum width of the pier, its shape, and flow direction.

Larras (1963) analyzed available scour data from various rivers in France and model studies and developed the equation referred to herein as the "Larras equation":

$$
y_{s}=1.42 K_{S 2} b^{0.75} \text {, }
$$

where $\quad K_{S 2}$ is a coefficient based on the shape of the pier nose (1.0 for cylindrical piers and 1.4 for rectangular piers). 
Larras stated that the depth of scour would be greater for unstable riverbeds than for stable riverbeds because of the inadequate supply of bed material to the scoured area in unstable beds. Because Larras's field measurements were only point measurements of scour depth made after a flood had passed, those data may not properly represent the depth of equilibrium scour (Shen and others, 1969). Equation 29 depends only on pier width and is independent of the hydraulics.

\section{Laursen}

Laursen (1962) used the results of his investigation of scour in a long contraction to develop equations for scour at bridge piers and abutments. Laursen stated:

The flow at the crossing cannot be considered uniform, but the solutions for the long contraction can be modified to describe the scour at bridge piers and abutments with the use of experimentally determined coefficients. (Laursen, 1962, p. 170)

Many flume experiments were done to evaluate the importance of alignment of piers to the flow, length-to-width ratio of the piers, approach-flow velocity, depth, and sediment size. The dimensionless Laursen equation for pier scour is

$$
\frac{b}{y_{o}}=5.5\left(\frac{y_{s}}{y_{o}}\right)\left(\left[\left(\frac{1}{11.5}\right)\left(\frac{y_{s}}{y_{o}}\right)+1\right]^{1.70}-1\right) .
$$

Equation 30 requires an iterative solution procedure to determine $y_{s}$. Laursen found that the depth of scour was not strongly influenced by the flow velocity or sediment size for live-bed conditions. Laursen (1962) concluded that the maximum depth of live-bed scour is uniquely determined by pier geometry; however, these basic variables cannot be isolated in equation 30. Laursen (1962) concluded that the maximum depth of scour was uniquely determined by the geometry and that the width of the scour holes was approximately $2.75 y_{s}$.

The shape of the pier is also important if the pier is aligned with the flow. Therefore, the depth of scour from equation $\mathbf{3 0}$ must be corrected for pier shape if the pier is aligned with the flow,

$$
y_{s}=K_{S 1} y_{s} \text {, }
$$

and for attack angle if the pier is not aligned with the flow,

$$
y_{s}=K_{\alpha L} y_{s},
$$

where $K_{\alpha L}$ is a coefficient based on the angle of the approach flow referenced to the bridge pier (fig. 39) and

$K_{S 1}$ is a coefficient based on the shape of the pier nose (table 7). 


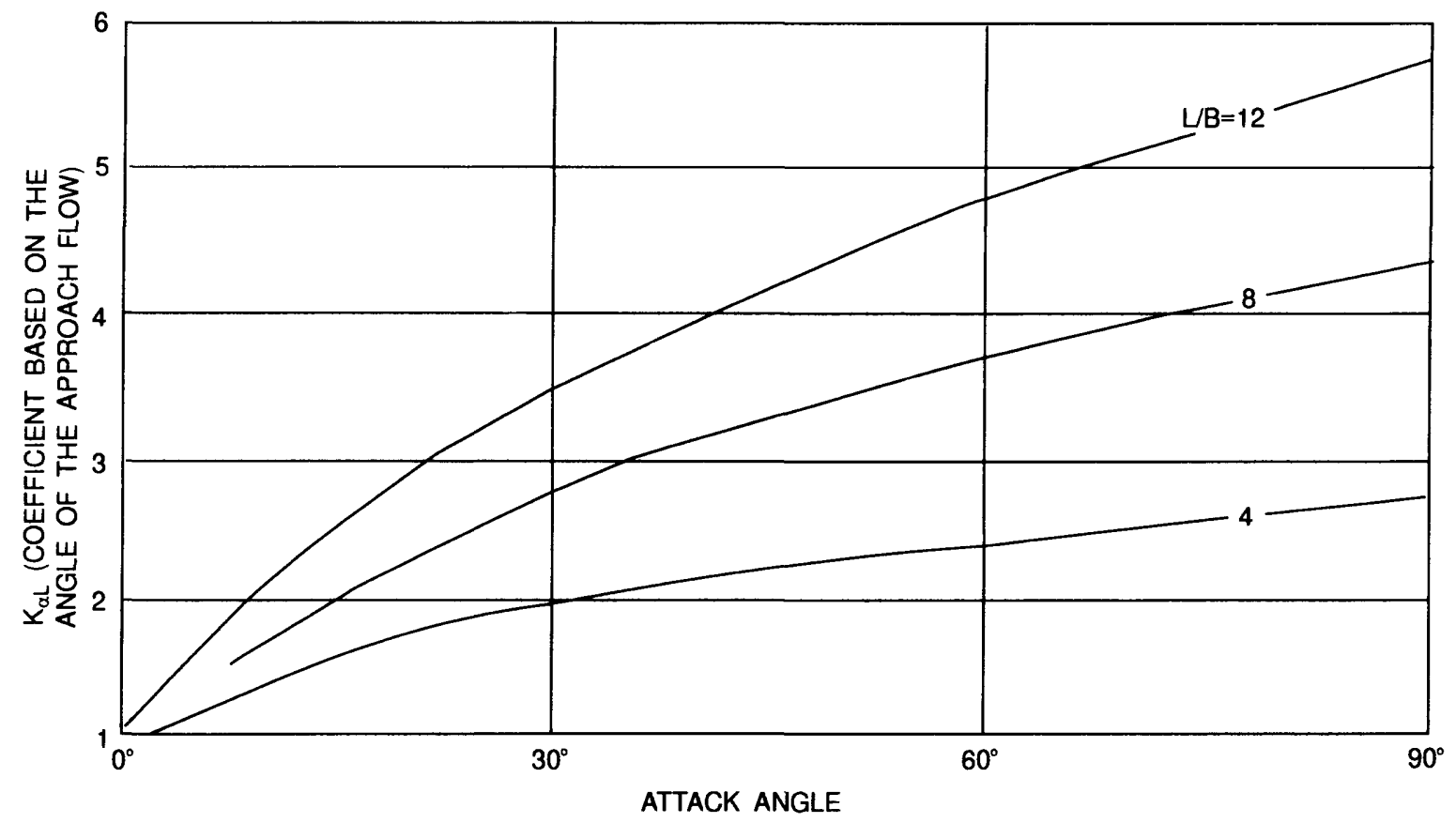

Figure 39. Effect of attack angle (from Laursen, 1962).

Table 7. Pier-shape coefficients

[From Laursen, 1962, $\mathrm{K}_{\mathrm{S} \text { I }}$, shape coefficients for nose forms; used only for piers aligned with flow]

\begin{tabular}{lcc}
\hline \multicolumn{1}{c}{ Nose form } & Length-width ratio & $\boldsymbol{K}_{\boldsymbol{S 1}}$ \\
\hline Rectangular & --- & 1.0 \\
Semicircular & -- & .90 \\
Elliptic & $2: 1$ & .80 \\
& $3: 1$ & .75 \\
Lenticular & $2: 1$ & .80 \\
& $3: 1$ & .70 \\
\hline
\end{tabular}




\section{Melville and Sutherland}

Melville and Sutherland (1988) presented a design method based on numerous laboratory experiments in New Zealand (Melville, 1975; Ettema, 1976, 1980; Chee, 1982; Chiew, 1984: Baker, 1986). This design method is based on the premise that the ultimate depth of scour is 2.4 times the pier width for flows aligned with the pier. They supplemented this simple relation with $K$ factors for the effect of flow intensity, depth of flow, bed material, pier shape, and attack angle. The basic equation, referred to herein as the "Melville and Sutherland equation," is:

$$
y_{s}=K_{I} K_{d} K_{y} K_{\alpha L} K_{s} b \text {, }
$$

where $K_{I}$ is the coefficient for flow intensity, defined as

$$
\begin{gathered}
K_{I}=2.4\left|\frac{V_{o}-\left(V_{a}-V_{c}\right)}{V_{c}}\right| \text { if } \frac{V_{o}-\left(V_{a}-V_{c}\right)}{V_{c}}<1 \text { and } \\
K_{I}=2.4 \text { if } \frac{V_{o}-\left(V_{a}-V_{c}\right)}{V_{c}}>1 ;
\end{gathered}
$$

$V_{c}$ is the critical velocity, defined as

$$
V_{c}=5.75 u_{*_{c}} \log \left(5.53 \frac{y_{o}}{d_{50}}\right)
$$

$u_{*_{c}}$ is the critical shear velocity, in meters per second, determined from figure 40 for $\mathrm{d}_{50}$ less than $60 \mathrm{~mm}$ and for $d_{50}$ greater than $60 \mathrm{~mm}$ as $0.03 d_{50}{ }^{0.5}$;

$V_{a}$ is the critical velocity of the armor layer, defined as

$$
V_{a}=0.8 V_{c a} \quad \text { if } \quad V_{a}>V_{c},
$$

otherwise $V_{a}=V_{c}$; and

$V_{c a}$ is the critical velocity of the armor layer determined by use of equation 36 and $d_{50 a}$.

Chin (1985) presented the following equation relating $\sigma$ and $d_{50}$ of a given bed material to the maximum grain size of the armor layer $\left(d_{\max }\right)$ for that bed material. This equation is based on the assumption that $d_{\text {max }}$ can be approximated by the $d_{95}$ and that bed-material particle sizes are log-normally distributed. Chin further stated that the median grain size of the armor layer $\left(d_{50 a}\right)$ is approximately equal to $d_{\text {max }} / 1.8$; consequently, equation 38 can be written to provide an estimate of $d_{50 a}$ :

$d_{50 a}$ is the median grain size of the armor layer defined as

$$
d_{50 a}=0.556 \sigma^{1.65} d_{50}
$$

s is the geometric standard deviation of the bed material; 
$K_{d}$ is the coefficient for sediment size, defined as

$$
\begin{gathered}
K_{d}=1.0 \text { if } b / d_{50} \geq 25 \text { and } \\
K_{d}=0.57 \log \left(2.24 \frac{b}{d_{50}}\right) \quad \text { if } b / d_{50}<25 ;
\end{gathered}
$$

$K_{y}$ is the coefficient for flow depth, defined as

$$
\begin{gathered}
K_{y}=1.0 \quad \text { if } y_{o} / b \geq 2.6 \text { and } \\
K_{y}=0.78\left(\frac{y_{o}}{b}\right)^{0.255} \quad \text { if } \quad y_{o} / b<2.6 ;
\end{gathered}
$$

$K_{\alpha L}$ is the coefficient for flow alignment and is determined from Laursen (1962) (see fig. 39); and

$K_{s}$ is the coefficient for pier shape and is consistent with the coefficients presented by Laursen (1962), modified so that cylindrical shapes have a value of 1.0 and square shapes have a value of 1.1 .

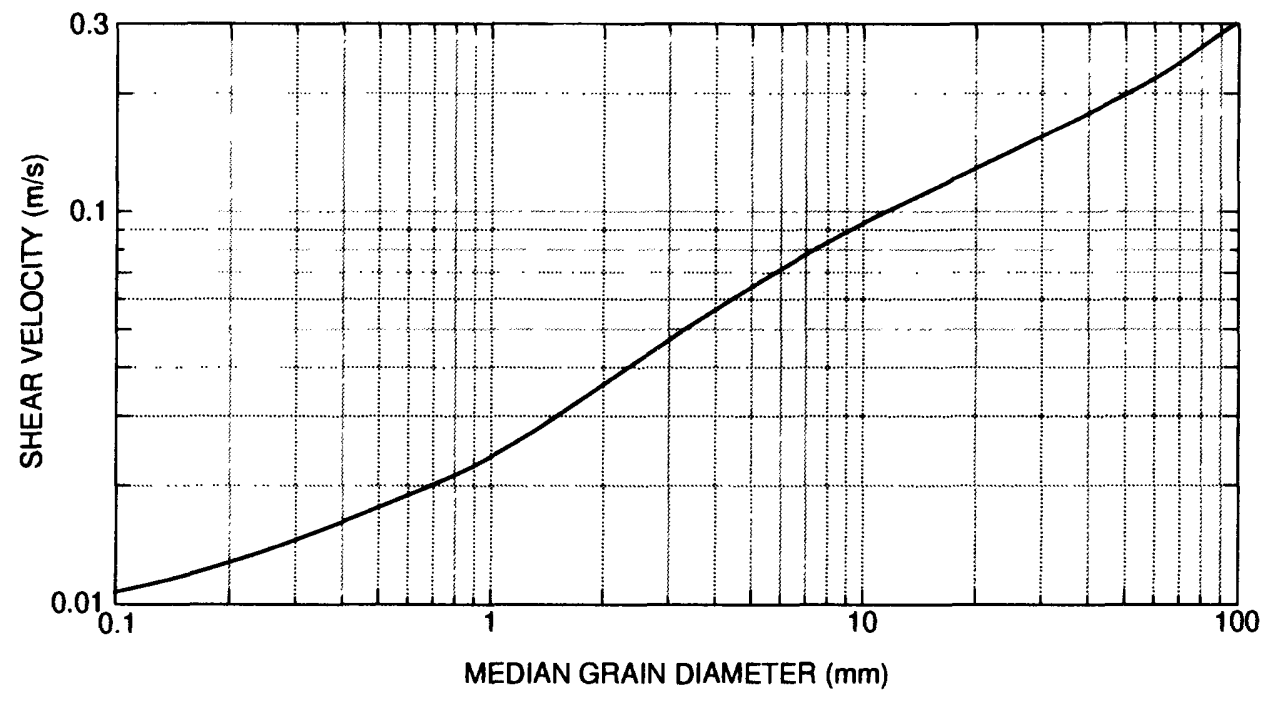

Figure 40. Shields chart for determination of the critical shear velocity of uniform sediments in water (from Melville and Sutherland, 1988). 


\section{Mississippi}

Wilson (1995) compiled and collected 190 measurements of local scour at bridge piers between 1938 and 1994 at 22 sites on streams in Mississippi. An analysis of the data was used to develop an envelope-curve equation for the measured data:

$$
\frac{y_{s}}{b_{e}}=0.9\left(\frac{y_{o}}{b_{e}}\right)^{0.4} \text {. }
$$

Solving equation 44 for $y_{s}$ results in

$$
y_{s}=0.9\left(\frac{y_{o}}{b_{e}}\right)^{0.4}\left(b_{e}\right) \text {, }
$$

referred to herein as the "Mississippi equation." The 190 measurements of local scour at bridge piers comprise 121 real-time measurements during the investigation and 69 historical measurements collected before 1990 .

\section{Shen}

Through a series of experiments, Shen and others (1969) determined that the basic mechanism of local scour was the vortex systems caused by the pressure field induced by the pier. Further analysis of the vortex systems showed that the strength of the horseshoe vortex system was a function of the pier Reynolds number, as follows:

$$
\boldsymbol{R}_{p}=\frac{V_{o} h}{v}
$$

where $\quad \boldsymbol{R}_{p}$ is pier Reynolds number and

$$
v \quad \text { is kinematic viscosity of water. }
$$

According to Shen and others (1969, p. 1925), "Since the horseshoe vortex system is the mechanism of local scour and the strength of the horseshoe vortex system is a function of the pier Reynolds number, the equilibrium depth of scour should be functionally related to the pier Reynolds number."

All known data at the time were used to investigate the influence of the pier Reynolds number on the depth of scour around bridge piers. The analysis showed that the depth of scour rises sharply as the pier Reynolds number increases to a point, then begins to decline as the pier Reynolds number continues to increase. A least-squares regression of the data with a pier Reynold's number less than 50,000 resulted in the following equation:

$$
y_{s}=0.00073 R_{p}^{0.619}
$$

which seems to form an envelope for all data (Shen and other 1969, p. 1931). This relation is referred to herein as the "Shen equation." Evaluation of this equation showed that the effect of pier size prevented the equation from collapsing all the data into one line, even for a given grain size. A definite separation of the data by sand size also was observed. Therefore, the Shen equation does not 
adequately account for the pier shape and the size of the bed material. Shen and others (1969) concluded that this equation could be used to provide a conservative estimate of clear-water scour, but that it was too conservative to be used for live-bed conditions. They suggested use of the equations by Larras (1963) and Breusers (1964-1965) for live-bed conditions.

Maza and Sanchez (1964) developed a relation between the ratio of depth of scour to pier width and the pier Froude number. Shen and others (1969) used all the available data in which median grain diameter of bed material was smaller than $0.52 \mathrm{~mm}$ in further investigations of the effects of the pier Froude number. They found that, for pier Froude numbers less than 0.2 and fine sands, the depth of scour increases rapidly as the pier Froude number increases; however, for pier Froude numbers greater than 0.2 and coarser sands, the depth of scour increases only moderately with increases in the pier Froude number. Therefore, two equations, referred to herein as "the Shen-Maza equations," were used to fit the data:

$$
\begin{gathered}
y_{s}=11.0 b \boldsymbol{F}_{p}^{2} \text { for } \quad \boldsymbol{F}_{p}<0.2 \text { and } \\
y_{s}=3.4 b \boldsymbol{F}_{p}^{0.67} \text { for } \boldsymbol{F}_{p}>0.2,
\end{gathered}
$$

where $\quad \boldsymbol{F}_{p}$ is pier Froude number, defined as, $\frac{V_{o}}{\sqrt{g b}}$. 


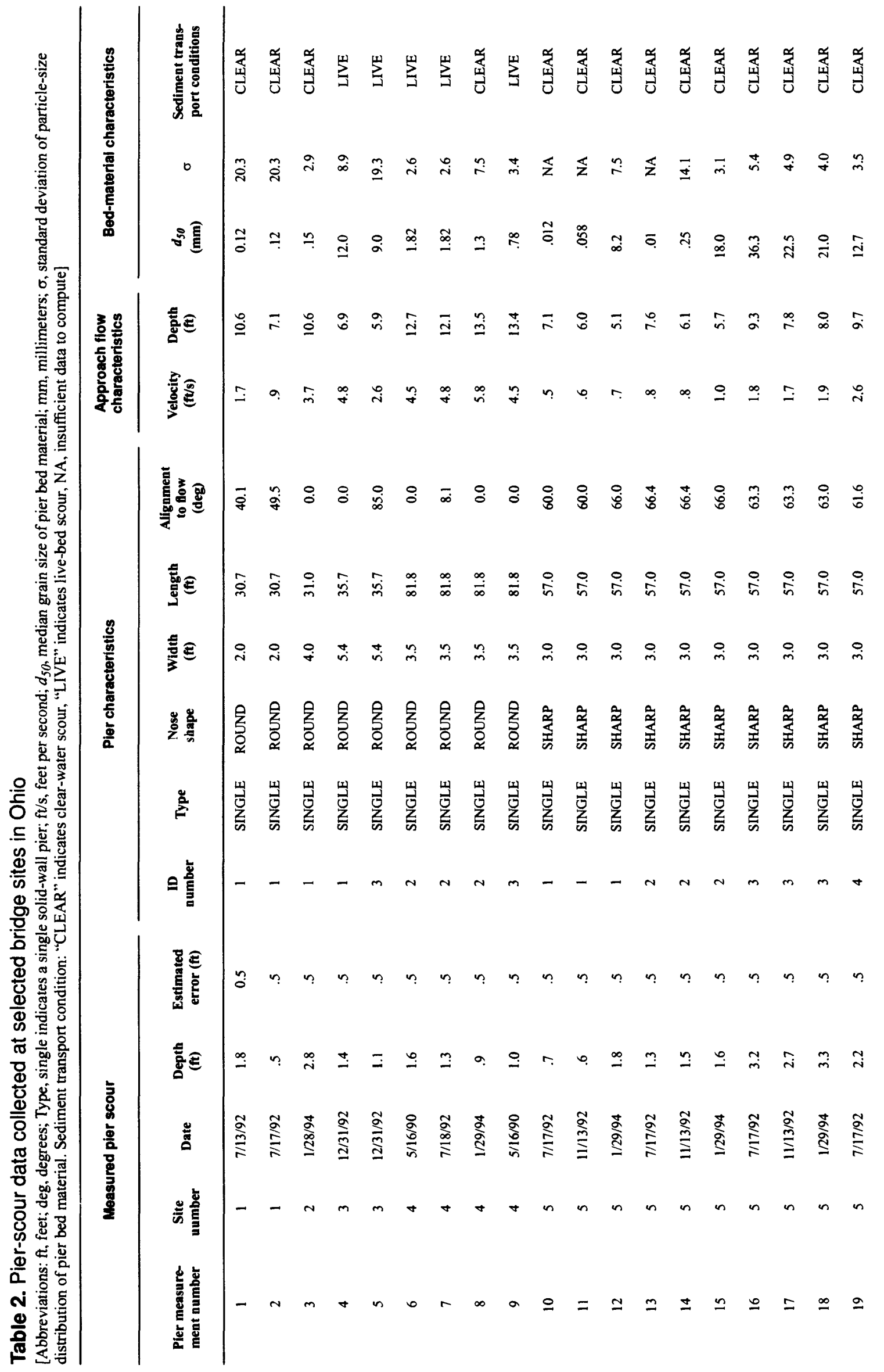




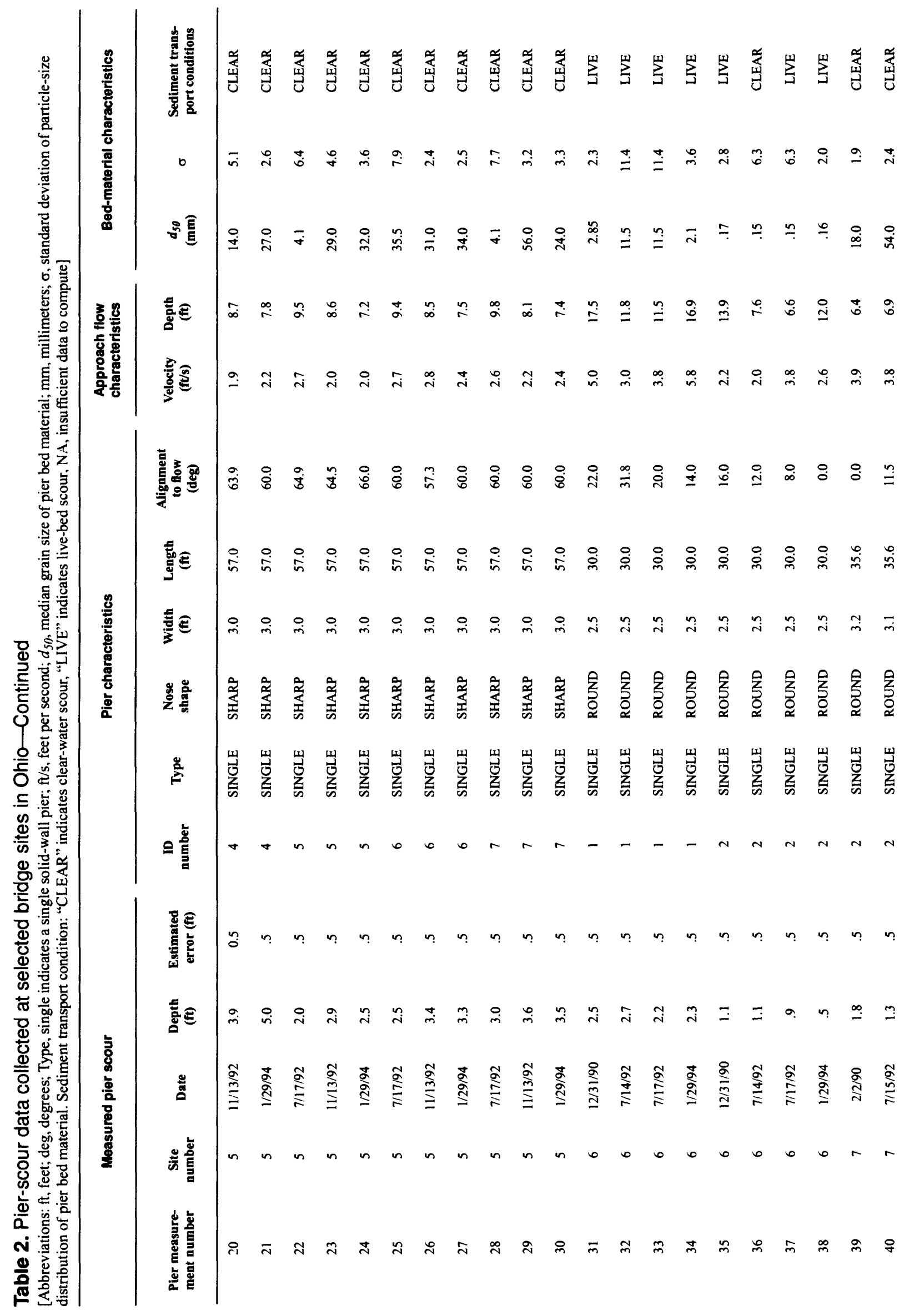




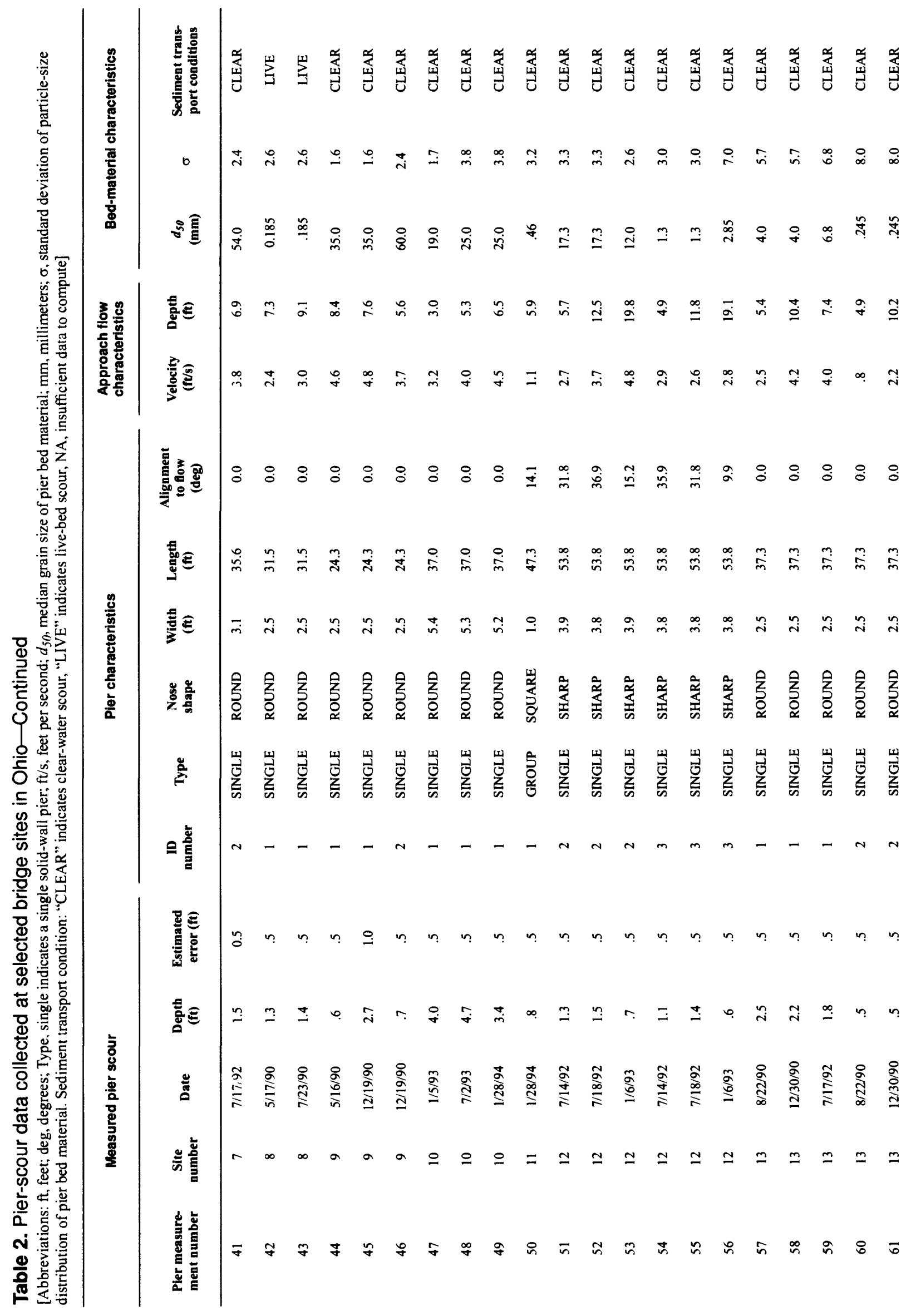




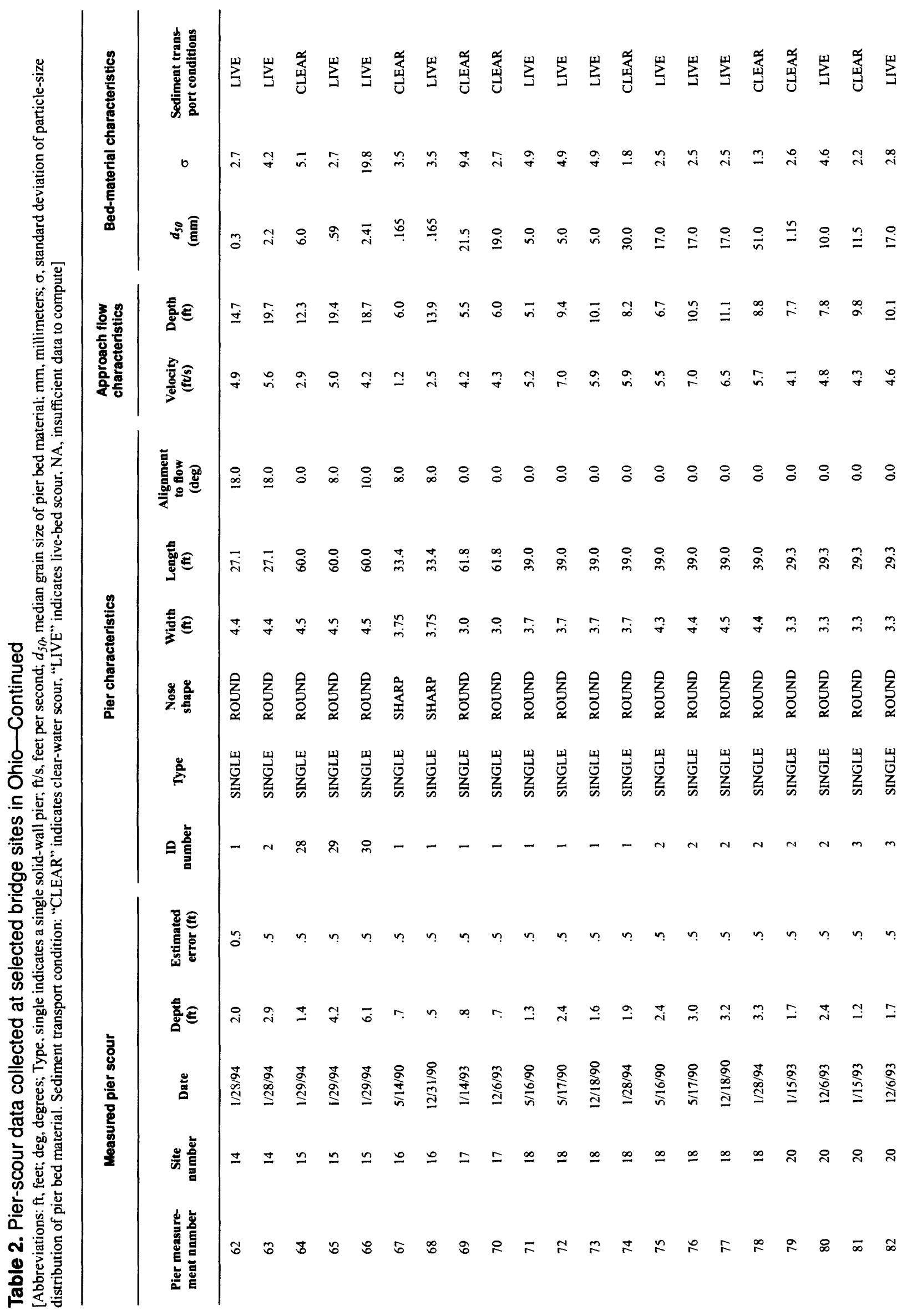




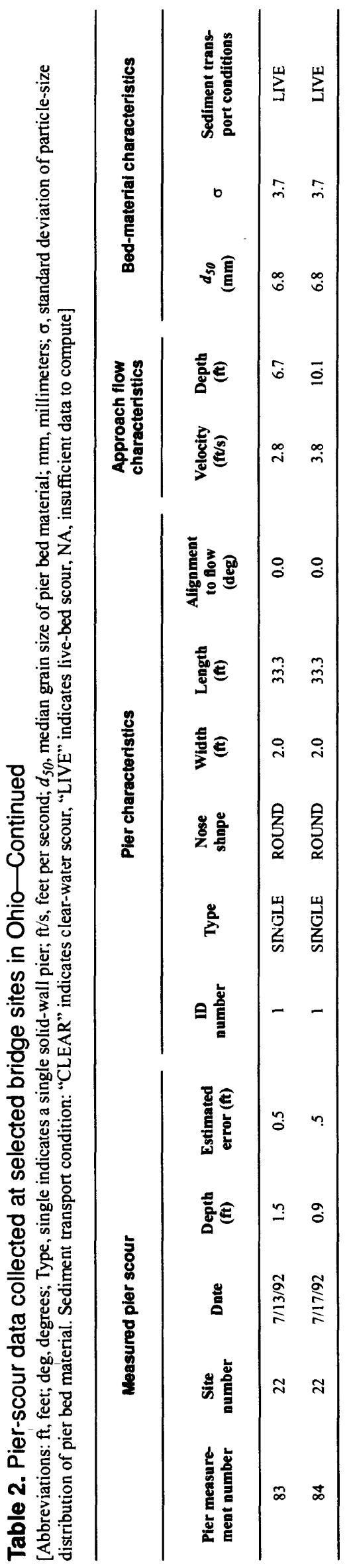

